\title{
Differentiation of species complexes in Phyllosticta enables better species resolution
}

\author{
Norphanphoun $\mathrm{C}^{1,2,3,4}$, Hongsanan $S^{5}$, Gentekaki $E^{1,4}$, Chen $\mathrm{YJ}^{1,4}$, Kuo $\mathrm{CH}^{2}$ and \\ Hyde $\mathrm{KD}^{1,3,4^{*}}$
}

${ }^{1}$ Center of Excellence in Fungal Research, Mae Fah Luang University, Chiang Rai 57100, Thailand

${ }^{2}$ Department of Plant Medicine, National Chiayi University, 300 Syuefu Road, Chiayi City 60004, Taiwan

${ }^{3}$ Mushroom Research Foundation, 128 M.3 Ban Pa Deng T. Pa Pae, A. Mae Taeng, Chiang Mai 50150, Thailand

${ }^{4}$ School of Science, Mae Fah Luang University, Chiang Rai 57100, Thailand

${ }^{5}$ Guangdong Provincial Key Laboratory for Plant Epigenetics, Shenzhen Key Laboratory of Microbial Genetic Engineering, College of Life Science and Oceanography, Shenzhen University, Shenzhen 518060, People's Republic of China

Norphanphoun C, Hongsanan S, Gentekaki E, Chen YJ, Kuo CH, Hyde KD 2020 - Differentiation of species complexes in Phyllosticta enables better species resolution. Mycosphere 11(1), 25422628, Doi 10.5943/mycosphere/11/1/16

\begin{abstract}
Phyllosticta species have worldwide distribution and are pathogens, endophytes, and saprobes. Taxa have also been isolated from leaf spots and black spots of fruits. Taxonomic identification of Phyllosticta species is challenging due to overlapping morphological traits and host associations. Herein, we have assembled a comprehensive dataset and reconstructed a phylogenetic tree. We introduce six species complexes of Phyllosticta to aid the future resolution of species. We also introduce a new species, Phyllosticta rhizophorae isolated from spotted leaves of Rhizophora stylosa in mangrove forests of Taiwan. Phylogenetic analysis based on combined sequence data of ITS, LSU, efl $\alpha$, actin and gapdh loci coupled with morphological evidence support the establishment of the new species. We synonymize strains of $P$. capitalensis (CPC 20508 and CPC20509) under the new species. Six strains (CBS 173.77, CBS 119720, CPC 17748, CPC 20252, CPC 20269, and CBS 123404) are unnamed species based on phylogenetic analyses and nucleotide polymorphisms and probably represent new species. The phylogenetic relationships of Phyllosticta species are reappraised and suggestions are given for future work.
\end{abstract}

Key words - 1 New Species - Microfungi - Morphology - Phylogenetic Analysis Phyllostictaceae - Rhizophoraceae - Synonym - Taxonomy

\section{Introduction}

Mangroves are forests situated in intertidal zones in tropical and subtropical backwaters, estuaries, deltas, and lagoons. They are important for wetland ecosystems providing numerous valuable services to the marine environment. Mangroves provide protection to coastal communities against natural hazards such as cyclones, tsunamis, and shoreline erosion (Saenger 2002, FAO 2007). Mangroves are found in Africa, North and Central America and Asia, including Taiwan (Alias \& Jones 2009, Alias et al. 2010). The fungi in mangoves are important in nutrient cycling helping to provide detritus and nutrients for mangrove inhabitants (Hyde \& Jones 1988, Hyde \& 
Lee 1998, Hyde et al. 1998, Thatoi et al. 2012). However, there have been no detailed diversity studies of terrestrial mangrove ecosystems in comparison to other environments (Beger et al. 2010). Previous studies have reported endophytic fungi on mangrove trees (Doilom et al. 2017, Rashmi et al. 2019). For example, Thatoi et al. (2013) reported more than 200 species of endophytic fungi from mangroves in India, Kumar et al. (2019) described Neopestalotiopsis alpapicalis on Rhizophora apiculata and R. mucronata from Thailand, and Norphanphoun et al. (2019) established new species of Neopestalotiopsis, Pestalotiopsis, and Pseudopestalotiopsis species from leaf spot and asymptomatic leaves from mangrove plants in Thailand. Several studies have also reported on fungal pathogens of mangroves. For example, leaf spots disease caused by pathogenic fungi include Anthostomella on Rhizophora mangle in Puerto Rico (Stevens 1920), Cercospora on R. mangle in Florida (McMillan 1964), Pestalotiopsis sp., Colletotrichum sp., and Polystigma sonneratiae on Rhizophora sp. (Hyde \& Cannon 1992, Xu et al. 2009), and Pseudocercospora avicenniae on Avicennia marina (Shivas et al. 2009). Other diseases include heart and butt rot disease caused by Heterobasidion annosum, Ganoderma, Phellinus sp., and Inonotus sp. on Rhizophora sp. (Ryvarden 2000, Fox 2001, Sakayaroj et al. 2012), canker and dieback caused by Phytophthora cinnamomi on Rhizophora sp. (Vollbrecht et al. 1995, Barnard 2000, Kinge \& Mih 2011). Cytospora species have been associated with dead branches of Lumnitzera racemosa, Xylocarpus granatum and X. moluccensis in Thailand (Norphanphoun et al. 2018).

In 1995, mangrove areas in Taiwan covered 287 ha, which represents only a tiny proportion of the total area of mangroves worldwide (Hsueh 1995). Four mangrove plant species are found in Taiwan, all of which have been declared endangered. These are Avicennia marina, Lumnitzera racemose, Kandelia candel and Rhizophora stylosa (Fan 2002, Pang et al. 2011). Previous restoration efforts of mangroves in Taiwan have been only partially successful and deforestation continues with annual declines of mangrove cover. One of the reasons for the decline is ineffective disease management (Hsueh 1995, Fan 2002, Pang et al. 2011). Several organisms are responsible for causing diseases of mangrove plants, including fungi. Fungi associated with the intertidal part of mangroves in Taiwan are relatively poorly studied and data on diseases of mangroves are sparse. The taxa collected from mangrove areas in Taiwan have mostly been saprobic marine fungi (Pang et al. 2011). Since mangroves in Taiwan represent a negligible proportion of the total mangrove area worldwide, therefore, very few authors have focused on mangrove research in the area (Fan 2002, Pang et al. 2011).

Phyllosticta was introduced by Persoon (1818) and belongs to Phyllostictaceae in Botryosphaeriales (Hongsanan et al. 2020, Wijayawardene et al. 2020). Phyllosticta is an earlier name of the asexual morph Guignardia introduced by Viala \& Ravaz (1892). The earlier name takes precedence based on the International Code for Nomenclature of Algae, Fungi and Plants (http://www.iapttaxon.org/nomen/main.php?page=title). Currently, the number of records of Phyllosticta in search engines is higher than that of Guignardia (Google Scholar, Index Fungorum, Species Fungorum, MycoBank and GenBank). Phyllosticta species are endophytes but are also associated with leaf spots of numerous plants and have a worldwide distribution on a wide range of plants (Okane et al. 2003, Glienke et al. 2011, Wikee et al. 2011, 2013b, Rashmi et al. 2019). There are 3,210 epithets of Phyllosticta listed in Index Fungorum 2020 (April 18, 2020). van der Aa (1973) described 46 species of Phyllosticta with 12 sexual and 17 spermatial morphs. van der Aa \& Vanev (2002) revised all species of Phyllosticta and accepted 190 epithets. Wikee et al. (2013b) recognized 170 species names based on multi-locus analysis and introduced Phyllostictaceae to accommodate Phyllosticta. Previously, many examined isolates of Phyllosticta were identified based on a combination of morphological data and phylogenetic analysis (Guarnaccia et al. 2017, Tran et al. 2019). However, sequence data from type material is not available for many species of Phyllosticta, and thus additional research studies focusing on neo- or epitypification are required in order to clarify their taxonomic placement. Evolutionary relationships within Phyllosticta are also unclear, despite intensive study (Delsuc et al. 2005). Thus, further analyses using larger datasets in 
terms of both taxa and loci are necessary to improve phylogenetic resolution within Phyllosticta. These approaches have been used successfully for other fungal taxa (Rokas \& Carroll 2005).

Herein, we have assembled a comprehensive dataset of five loci containing all species denoted as Phyllosticta in GenBank. Based on the resulting phylogenetic tree, we introduce six workable species complex clades. A new species, Phyllosticta rhizophorae is also introduced from Taiwan. Two published strains of $P$. capitalensis are synonymized under the new species. Six strains of $P$. capitalensis are treated as unnamed species based on nucleotide polymorphisms and phylogenetic evidence. Seventeen strains are excluded from Phyllosticta based on BLAST searches and phylogenetic placement.

\section{Materials \& methods}

\section{Sample collection and specimen examination}

Fresh leaf samples were collected in 2018, from Rhizophora stylosa from Shicao, Taiwan. Fresh specimens were taken to the laboratory in paper bags, examined and described following the methods in Norphanphoun et al. (2017). Morphological characters of conidiomata were examined using a Zeiss Axioskop 2 plus compound microscope (Carl Zeiss Microscopy, LLC, NY, USA). Micro-morphology was studied using a Zeiss Axioskop 2 mot plus compound microscope (Carl Zeiss Microscopy, LLC, NY, USA). All image measurements were made with the ZEN2 (blue edition) software. Photo-plates were made using Adobe Photoshop CC 2019 version: 20.0.1 20181029.r.41 2018/010/29: $1197484 \times 64$ (Adobe Systems, CA, USA).

Cultures were obtained using the tissue isolation method outlined in Norphanphoun et al. (2018). Single hyphal tips were transferred onto 2\% potato agar (PA) plates and flasks at room temperature $\left(25^{\circ} \mathrm{C} \pm 2\right)$ throughout a two-week period: $24 \mathrm{hr}$ dark for asexual morph, and $24 \mathrm{hr}$ light for sexual morph. Culture characteristics were examined and recorded after 5, 7, 14 and 30 days. Morphological characters in culture were examined throughout the cultivation period. Pure cultures were maintained on PA for further studies. Dried and living cultures have been deposited in the Department of Plant Medicine, National Chiayi University, Taiwan (NCYU) and duplicates in culture collection at Mae Fah Luang University (MFLUCC), Chiang Rai, Thailand. Facesoffungi numbers were obtained as in Jayasiri et al. (2015).

\section{Pathogenicity testing}

Healthy leaves (leaves attached on branches) of Rhizophora stylosa were washed with distilled water, wiped with 70\% ethanol, dried with sterile tissue paper, and covered with sterile wet cotton at the base of branch stalks. To test Koch's postulates, we followed the inoculation methods of Than et al. (2008). Eight experiments with three replications each were designed for this study. Of these, four were conducted using wounded leaves by pricking them with a pin, and another four using unwounded leaves. Mycelium plugs $(0.7 \mathrm{~mm}$ diam) of 14-day-old colonies on PDA were used for experiment 1: wounded leaves + mycelium plugs; experiment 2: unwounded leaves + mycelium plugs; experiment 3: spore suspension $\left(5 \times 10^{4} / \mathrm{ml}\right)$ from 14 -day-old colonies on PA was used for wounded + spores suspension; and experiment 4: unwounded + spores suspension. Sterile water and PDA agar plugs served as control treatments as follows; experiment 5: wounded + PDA agar; experiment 6: unwounded + PDA agar; experiment 7: wounded + sterile water; and experiment 8: unwounded + sterile water. All experiments were kept individually in moist chambers for 1 week and observed for symptom expression every other day. After 7 days, if positive, the fungus was re-isolated from any tissue showing lesions and the isolate was considered to be pathogenic; absence of symptoms on leaves classified the isolate as non-pathogenic.

\section{DNA extraction, PCR amplification and sequencing}

Genomic DNA was extracted from fresh fungal mycelia growing on PA at room temperature $\left(25^{\circ} \mathrm{C} \pm 2\right)$ for two weeks using an E.Z.N.A ${ }^{\circledR}$ Fungal DNA Mini Kit, D3390-02, (Omega Bio-tek, Inc., GA) following the manufacturer's protocols. Polymerase chain reactions (PCR) were carried 
out using the following primer pairs: ITS1/ITS4 to amplify the internal transcribed spacer region (ITS) (White et al. 1990), LROR/LR5 for the 28S large subunit ribosomal RNA gene (LSU) (White et al. 1990), act512F/act738R for actin (Carbone \& Kohn 1999), Gpd1-LM/Gpd2-LM for partial glyceraldehyde-3-phosphate dehydrogenase region (gapdh) (Myllys et al. 2002).

The amplification reactions were carried out using the following protocol: $50 \mu \mathrm{L}$ reaction volume containing $2 \mu \mathrm{l}$ of DNA template, $2 \mu \mathrm{L}$ (10 $\mu \mathrm{M}$ stock concentration) of each forward and reverse primers, $25 \mu \mathrm{l}$ of $2 \times$ Power Taq PCR MasterMix (Tri-I Biotech, Taipei, Taiwan) and $19 \mu \mathrm{l}$ of double-distilled water $\left(\mathrm{ddH}_{2} \mathrm{O}\right)$. The PCR thermal cycling program for each locus is described in Table 1. PCR products were analysed using 1.5\% agarose gels containing the Safeview DNA stain (GeneMark, Taipei, Taiwan) to confirm presence of amplicons at the expected molecular weight. Purification and sequencing of PCR products with the amplification primers mentioned above were carried out at Tri-I Biotech, Taipei, Taiwan.

Table 1 Polymerase chain reactions (PCR) thermal cycling programs for each locus.

\begin{tabular}{|c|c|c|}
\hline Gene & Primers & PCR thermal cycle protocols* \\
\hline ITS & ITS1/ ITS4 & $\begin{array}{l}\mathrm{ID} 95^{\circ} \mathrm{C} \text { for } 3 \mathrm{~min}, 40 \text { cycles of } \mathrm{D} \text { at } 95^{\circ} \mathrm{C} \text { for } 30 \mathrm{~s}, \mathrm{~A} \text { at } 55^{\circ} \mathrm{C} \text { for } 50 \mathrm{~s}, \mathrm{E} \text { at } \\
72^{\circ} \mathrm{C} \text { for } 1 \mathrm{~min}, \mathrm{FE} \text { at } 72^{\circ} \mathrm{C} \text { for } 7 \mathrm{~min}\end{array}$ \\
\hline LSU & LROR/ LR5 & $\begin{array}{l}\text { ID } 95^{\circ} \mathrm{C} \text { for } 3 \mathrm{~min}, 34 \text { cycles of } \mathrm{D} \text { at } 95^{\circ} \mathrm{C} \text { for } 30 \mathrm{~s}, \mathrm{~A} \text { at } 51^{\circ} \mathrm{C} \text { for } 50 \mathrm{~s}, \mathrm{E} \text { at } \\
72^{\circ} \mathrm{C} \text { for } 1 \mathrm{~min}, \mathrm{FE} \text { at } 72^{\circ} \mathrm{C} \text { for } 10 \mathrm{~min}\end{array}$ \\
\hline actin & act512F/ act738R & $\begin{array}{l}\text { ID } 95^{\circ} \mathrm{C} \text { for } 5 \text { min, } 40 \text { cycles of } \mathrm{D} \text { at } 95^{\circ} \mathrm{C} \text { for } 40 \mathrm{~s} \text {, A at } 58^{\circ} \mathrm{C} \text { for } 30 \mathrm{~s} \text {, E at } \\
72^{\circ} \mathrm{C} \text { for } 1 \mathrm{~min}, \mathrm{FE} \text { at } 72^{\circ} \mathrm{C} \text { for } 5 \text { min }\end{array}$ \\
\hline gapdh & $\begin{array}{l}\text { Gpd1-LM/ Gpd2- } \\
\text { LM }\end{array}$ & $\begin{array}{l}\text { ID } 94^{\circ} \mathrm{C} \text { for } 5 \mathrm{~min}, 40 \text { cycles of } \mathrm{D} \text { at } 94^{\circ} \mathrm{C} \text { for } 30 \mathrm{~s} \text {, A at } 52^{\circ} \mathrm{C} \text { for } 30 \mathrm{~s} \text {, E at } \\
72^{\circ} \mathrm{C} \text { for } 30 \mathrm{~s} \text {, FE at } 72^{\circ} \mathrm{C} \text { for } 7 \text { min }\end{array}$ \\
\hline
\end{tabular}

*ID: initial denaturation; $\mathrm{D}$ = denaturation; $\mathrm{A}$ = annealing; $\mathrm{E}$ = elongation; $\mathrm{FE}$ = final extension

\section{Phylogenetic analysis}

Raw reads were edited and assembled into contigs using Geneious ${ }^{\circledR}$ version 11.1 .5 (http://www.geneious.com). The new sequences were used as queries to perform BLASTn against the nr database in GenBank. Similar sequences were retrieved, and multiple alignments were built. GenBank taxonomy browser was also used to check all sequences assigned as Phyllosticta in the database. ITSx 1.1, a Perl based software tool was used to extract ITS1, 5.8S and ITS2 sequences (Bengtsson-Palme et al. 2013). BioEdit version 7.2.3 (Hall 1999) was used to assign open reading frames of protein coding sequence of $\beta$-tubulin, and efl $\alpha$, according to reference sequences in GenBank database. Combined sequence data of all loci were used to perform maximum parsimony (MP), maximum likelihood (ML) and Bayesian inference analysis (BI). Two datasets were created. Dataset one consisted of 195 taxa (outgroup: Botryosphaeria obtusa strain CMW 8232 and B. stevensii strain CBS 112553), while dataset two was a subset of dataset one containing 74 strains (outgroup: P. cordylinophila strain MFLUCC 10-0166 and P. cordylinophila strain MFLUCC 120014). Outgroup sequences were selected based on preliminary analysis and results from the multigene phylogeny of dataset one. All taxa used for these analyses can be found in Table 3 . Phyllosticta abietis (AF312012) was not included in the analyses because only the ITS locus was available.

Sequences were aligned for each locus separately using the MAFFT v.7.110 online program (http://mafft.cbrc.jp/alignment/server/; Katoh \& Standley 2013). TrimAl (available on Phylemon 2.0 platform, Sánchez et al. 2011) was used to trim ambiguously aligned positions. BioEdit v. 7.0.5.3 was used for further manual adjustments wherever necessary (Hall 1999). A partition homogeneity test (PHT) was performed with PAUP* 4.0b10 to determine congruency of genes and whether they could be combined (Swofford 2002). The combined sequence alignments were obtained from MEGA v. 7.0.14 and v. 10.1.0 (Kumar et al. 2018). Geneious Prime ${ }^{\circledR}$ 2019.2.1 was used to convert file format to NEXUS for MP and BI analyses (http://www.geneious.com). 
Maximum parsimony analysis was performed using the CIPRES Science Gateway web server (PAUP on XSEDE; Miller et al. 2010), with 1000 bootstrap replicates using heuristic search with random stepwise addition and tree-bisection reconnection (TBR) algorithm. Maximum trees were set to 1000 and branches of zero length were collapsed. The following descriptive tree statistics were calculated: parsimony tree length (TL), consistency index (CI), retention index (RI), rescaled consistency index (RC) and homoplasy index (HI). For ML and BI analyses, the data were partitioned as follows: ITS1+ITS2, 5.8S, LSU, efl $\alpha$-exon, actin-exon, gapdh, efl $\alpha$-intron, actinintron. The software RAxML-HPC2 on XSEDE (Miller et al. 2010) was used to run ML analysis as implemented in the CIPRES Science Gateway web server, 1000 rapid bootstrap replicates were run using the GTRGAMMA model of nucleotide evolution. Bayesian inference analysis was performed using the Markov Chain Monte Carlo (MCMC) algorithm as implemented in CIPRES Science Gateway web server (MrBayes on XSEDE; Miller et al. 2010). The best-fit nucleotide substitution model for each partition was separately determined using MrModeltest version 2.2 (Table 2, Nylander 2004). Posterior probabilities were computed by running two runs with four chains each starting from random tree topology. 20,000,000 and 2,500,000 generations were run for dataset one and two, respectively. Trees were sampled every 100 generations. $25 \%$ of the trees were discarded as burn-in value with average standard deviation of split frequencies converged under 0.01 (Ronquist et al. 2012).

Table 2 The best-fit nucleotide substitution model for each dataset, selected by AIC in MrModeltest 2.2.

\begin{tabular}{l|c|c|c|c|c|c|c|c}
\hline Models & $\begin{array}{c}\text { ITS1+ } \\
\text { ITS2 }\end{array}$ & $\mathbf{5 . 8 S}$ & LSU & $\begin{array}{c}\text { ef1 } \boldsymbol{a} \\
\text { (exon) }\end{array}$ & $\begin{array}{c}\text { actin } \\
\text { (exon) }\end{array}$ & gapdh & $\begin{array}{c}\text { ef1 } \alpha \\
\text { (intron) }\end{array}$ & $\begin{array}{c}\text { actin } \\
\text { (intron) }\end{array}$ \\
\hline F81 & & & & & $\bullet$ & & & $\bullet$ \\
\hline F81+I & & & $\bullet$ & & & & & \\
\hline GTR & & & & & & $\bullet$ & & \\
\hline GTR+G & & & & & 0 & & & \\
\hline GTR+I+G & $\circ$ & & $\circ$ & & & 0 & 0 & \\
\hline HKY & & & & & & & $\bullet$ & \\
\hline HKY+G & & & & & & & & 0 \\
\hline JC & & $\bullet$ & & & & & & \\
\hline K80 & & & & $\bullet$ & & & & \\
\hline SYM & $\bullet$ & & & & & & &
\end{tabular}

$\circ$ Best-fit nucleotide substitution model for Fig. 1

- Best-fit nucleotide substitution model for Fig. 2

The phylogram was visualized in FigTree v1.4.0 (http://ree.bio.ed.ac.uk/software /figtree/; Rambaut 2014) and made in Adobe Illustrator CC version 23.0.1 (64-bit) and Adobe Photoshop CC version 20.0.1 release (Adobe Systems, CA, the USA). Newly generated sequences in this study are deposited in GenBank (Table 3). The finalized alignments and trees were deposited in TreeBASE, Figure 1: submission ID: 26535, Figure 2: submission ID: 26536.

\section{Results}

\section{Phylogenetic analysis}

The results from the partition homogeneity tests (PHT) were not significant (level $\leq 95 \%)$ for either phylogenetic tree, indicating that the individual datasets were congruent and could be combined. Phylogenetic trees from single loci were also generated (Supplementary figures 1-5) to examine topology and clade support. In this study, we introduce six clades as species complexes containing extant species of Phyllosticta. 
Table 3 GenBank Accession numbers of the sequences used for phylogenetic analysis in this study.

\begin{tabular}{|c|c|c|c|c|c|c|c|c|}
\hline \multirow[t]{2}{*}{ Species } & \multirow[t]{2}{*}{ Strain no.* } & \multirow[t]{2}{*}{ Host } & \multirow[t]{2}{*}{ Country } & \multicolumn{5}{|c|}{ GenBank no. } \\
\hline & & & & ITS & LSU & efla & actin & gapdh \\
\hline $\begin{array}{l}\text { Botryosphaeria } \\
\text { obtusa }\end{array}$ & CMW 8232 & Conifers & $\begin{array}{l}\text { South } \\
\text { Africa }\end{array}$ & AY972105 & - & DQ280419 & AY972111 & - \\
\hline B. stevensii & CBS 112553 & $\begin{array}{l}\text { culture from isotype } \\
\text { of Diplodia mutila }\end{array}$ & Not given & AY259093 & AY928049 & AY573219 & - & - \\
\hline $\begin{array}{l}\text { Phyllosticta } \\
\text { abieticola }\end{array}$ & CBS 112067 & Abies concolor & Canada & KF170306 & EU754193 & - & KF289238 & - \\
\hline P. acaciigena & CPC $28295^{\mathrm{T}}$ & Acacia suaveolens & Australia & KY173433 & KY173523 & - & KY173570 & - \\
\hline P. aloeicola & CPC $21020^{\mathrm{T}}$ & Aloe ferox & $\begin{array}{l}\text { South } \\
\text { Africa }\end{array}$ & KF154280 & KF206214 & KF289193 & KF289311 & KF289124 \\
\hline P. aloeicola & СРC 21021 & Aloe ferox & $\begin{array}{l}\text { South } \\
\text { Africa }\end{array}$ & KF154281 & KF206213 & KF289194 & KF289312 & KF289125 \\
\hline P. ardisiicola & NBRC $102261^{\mathrm{T}}$ & Ardisia crenata & Japan & AB454274 & - & - & AB704216 & - \\
\hline P. aristolochiicola & BRIP $53316^{\mathrm{T}}$ & $\begin{array}{l}\text { Aristolochia } \\
\text { acuminata }\end{array}$ & Australia & JX486129 & - & - & - & - \\
\hline P. aspidistricola & NBRC $102244^{\mathrm{T}}$ & Aspidistra elatior & Japan & AB454314 & - & - & AB704204 & - \\
\hline $\begin{array}{l}\text { P. aucubae- } \\
\text { japonicae }\end{array}$ & MAFF $236703^{\mathrm{T}}$ & Aucuba japonica & Japan & KR233300 & - & KR233310 & KR233305 & - \\
\hline P. austroafricana & CBS $144593^{\mathrm{T}}$ & $\begin{array}{l}\text { leaf spots of } \\
\text { unidentified } \\
\text { deciduous tree }\end{array}$ & $\begin{array}{l}\text { South } \\
\text { Africa }\end{array}$ & MK442613 & MK442549 & MK442704 & MK442640 & - \\
\hline P. azevinhi & MUCC0088 & Ilex pedunculosa & Japan & AB454302 & - & - & AB704226 & - \\
\hline P. beaumarisii & CBS 535.87 & $\begin{array}{l}\text { Muehlenbekia } \\
\text { adpressa }\end{array}$ & Australia & NR_145235 & NG_058040 & KF766429 & KF306232 & KF289074 \\
\hline P. bifrenariae & CBS $128855^{\mathrm{T}}$ & Bifrenaria harrisoniae & Brazil & JF343565 & KF206209 & JF343586 & JF343649 & JF343744 \\
\hline P. bifrenariae & CPC 17467 & Bifrenaria harrisoniae & Brazil & KF170299 & KF206260 & KF289207 & KF289283 & KF289138 \\
\hline P. brazilianiae & LGMF $330^{\mathrm{T}}$ & Mangifera indica & Brazil & JF343572 & KF206217 & JF343593 & JF343656 & JF343758 \\
\hline P. brazilianiae & LGMF 334 & Mangifera indica & Brazil & JF343566 & KF206215 & JF343587 & JF343650 & JF343752 \\
\hline P. camelliae & MUCC0059 & Camellia japonica & Japan & AB454290 & - & - & AB704223 & - \\
\hline P. capitalensis & CBS 226.77 & $\begin{array}{l}\text { Paphiopedilum } \\
\text { callosum }\end{array}$ & Germany & FJ538336 & KF206289 & FJ538394 & FJ538452 & JF343718 \\
\hline P. capitalensis & CBS 356.52 & Ilex sp. & Not given & FJ538342 & KF206300 & FJ538400 & FJ538458 & KF289087 \\
\hline P. capitalensis & CBS 100175 & Citrus sp. & Brazil & FJ538320 & KF206327 & FJ538378 & FJ538436 & JF343699 \\
\hline P. capitalensis & CBS 101228 & Nephelium lappaceum & Hawaii & FJ538319 & KF206325 & FJ538377 & FJ538435 & KF289086 \\
\hline P. capitalensis & CBS 114751 & Vaccinium sp. & $\begin{array}{l}\text { New } \\
\text { Zealand }\end{array}$ & EU167584 & EU167584 & FJ538407 & FJ538465 & KF289088 \\
\hline
\end{tabular}


Table 3 Continued.

\begin{tabular}{|c|c|c|c|c|c|c|c|c|}
\hline \multirow[t]{2}{*}{ Species } & \multirow[t]{2}{*}{ Strain no.* } & \multirow[t]{2}{*}{ Host } & \multirow[t]{2}{*}{ Country } & \multicolumn{5}{|c|}{ GenBank no. } \\
\hline & & & & ITS & LSU & efla & actin & gapdh \\
\hline P. capitalensis & CBS 115047 & $\begin{array}{l}\text { Aspidosperma } \\
\text { polyneuron }\end{array}$ & Brazil & FJ538323 & KF206318 & FJ538381 & FJ538439 & KF289077 \\
\hline P. capitalensis & CBS 115049 & Bowdichia nitida & Brazil & FJ538324 & KF206317 & FJ538382 & FJ538440 & KF289084 \\
\hline P. capitalensis & CBS 117118 & Musa acuminata & Indonesia & FJ538339 & JQ743603 & FJ538397 & FJ538455 & KF289090 \\
\hline P. capitalensis & CBS 120428 & Sansevieria sp. & Netherlands & JN692544 & KF206315 & JN692532 & JN692520 & JN692509 \\
\hline P. capitalensis & CBS 123373 & Musa paradisiaca & Thailand & FJ538341 & JQ743604 & FJ538399 & FJ538457 & JF343703 \\
\hline P. capitalensis & CBS $128856^{\mathrm{T}}$ & Stanhopea sp. & Brazil & JF261465 & KF206304 & JF261507 & JF343647 & JF343776 \\
\hline P. capitalensis & СРC 11867 & Acacia crassicarpa & Thailand & KF206181 & KF206283 & KF289184 & KF289260 & KF289108 \\
\hline P. capitalensis & СРC 13987 & Protea repens & Portugal & KF206183 & KF206281 & KF289176 & KF289263 & KF289083 \\
\hline P. capitalensis & СРС 14609 & Zyzygium sp. & $\begin{array}{l}\text { Republic of } \\
\text { Madagascar }\end{array}$ & KF206184 & KF206280 & KF289175 & KF289264 & KF289081 \\
\hline P. capitalensis & СРC 16590 & Citrus limon & Argentina & KF206185 & KF206272 & KF289177 & KF289271 & KF289091 \\
\hline P. capitalensis & СРС 16591 & Citrus limon & Argentina & KF206186 & KF206271 & KF289179 & KF289272 & KF289093 \\
\hline P. capitalensis & СРC 16592 & Citrus limon & Argentina & KF206187 & KF206270 & KF289178 & KF289273 & KF289092 \\
\hline P. capitalensis & СРС 17468 & Cymbidium sp. & Brazil & KF206188 & KF206259 & KF289189 & KF289284 & KF289120 \\
\hline P. capitalensis & CPC 20251 & Wild plant & Thailand & KC291333 & KF206252 & KC342553 & KC342530 & KF289101 \\
\hline P. capitalensis & СРC 20253 & Scheffera venulosa & Thailand & KF206192 & KF206250 & KF289181 & KF289293 & KF289102 \\
\hline P. capitalensis & СРC 20254 & $\begin{array}{l}\text { Saccharum } \\
\text { officinarum }\end{array}$ & Thailand & KC291335 & KF206249 & KC342555 & КС342532 & KF289103 \\
\hline P. capitalensis & СРC 20255 & Arecaceae & Thailand & KC291336 & KF206248 & КС342556 & KC342533 & KF289115 \\
\hline P. capitalensis & СРC 20256 & $\begin{array}{l}\text { Ophiopogon } \\
\text { japonicus }\end{array}$ & Thailand & KC291337 & KF206247 & KC342557 & КС342534 & KF289089 \\
\hline P. capitalensis & СРC 20257 & Ficus benjamina & Thailand & KC291338 & KF206246 & KC342558 & KC342535 & KF289099 \\
\hline P. capitalensis & CPC 20258 & $\begin{array}{l}\text { Ophiopogon } \\
\text { japonicus }\end{array}$ & Thailand & KC291339 & KF206245 & KC342559 & KC342536 & KF289094 \\
\hline P. capitalensis & СРC 20259 & Orchidaceae & Thailand & KC291340 & KF206244 & КС342560 & KC342537 & KF289104 \\
\hline P. capitalensis & СРC 20263 & Magnoliaceae & Thailand & KC291341 & KF206241 & КС342561 & KC342538 & KF289085 \\
\hline P. capitalensis & CPC 20265 & Euphobiaceae & Thailand & KF206194 & KF206239 & KF289182 & KF289297 & KF289105 \\
\hline P. capitalensis & СРC 20266 & Polyscias sp. & Thailand & KC291342 & KF206238 & KC342562 & KC342539 & KF289109 \\
\hline P. capitalensis & СРC 20267 & Baccaurea ramiflora & Thailand & KF206195 & KF206237 & KF289173 & KF306233 & KF289078 \\
\hline P. capitalensis & СРC 20268 & Hibiscus syriacus & Thailand & KC291343 & KF206236 & КС342563 & KC342540 & KF289117 \\
\hline P. capitalensis & CPC 20270 & Tectona grandis & Thailand & KC291345 & KF206234 & КС342565 & KC342542 & KF289110 \\
\hline P. capitalensis & СРC 20271 & Crinum asiaticum & Thailand & KF206196 & KF206233 & KF289183 & KF289298 & KF289106 \\
\hline P. capitalensis & CPC 20272 & Orchidaceae & Thailand & KC291346 & KF206232 & КС342566 & KC342543 & KF289079 \\
\hline
\end{tabular}


Table 3 Continued.

\begin{tabular}{|c|c|c|c|c|c|c|c|c|}
\hline \multirow[t]{2}{*}{ Species } & \multirow[t]{2}{*}{ Strain no.* } & \multirow[t]{2}{*}{ Host } & \multirow[t]{2}{*}{ Country } & \multicolumn{5}{|c|}{ GenBank no. } \\
\hline & & & & ITS & LSU & $e f 1 \alpha$ & actin & gapdh \\
\hline P. capitalensis & CPC 20274 & Mangifera indica & Thailand & KF206197 & KF206231 & KF289188 & KF289299 & KF289119 \\
\hline P. capitalensis & CPC 20275 & Polyalthia longifolia & Thailand & KC291347 & KF206230 & KC342567 & KC342544 & KF289107 \\
\hline P. capitalensis & CPC 20278 & Euphorbia milii & Thailand & КС291348 & KF206227 & КС342568 & КС342545 & KF289113 \\
\hline P. capitalensis & CPC 20423 & Philodendron sp. & Thailand & KC291349 & KF206226 & KC342569 & KC342546 & KF289116 \\
\hline P. capitalensis & CPC 20510 & Pyrrosia adnascens & Thailand & KF206200 & KF206223 & KF289174 & KF289304 & KF289080 \\
\hline P. capitalensis & LGMF 219 & Citrus sinensis & Brazil & KF206202 & KF206220 & JF261490 & KF289306 & JF343737 \\
\hline P. capitalensis & LGMF 220 & Citrus sinensis & Brazil & KF206203 & KF206219 & JF261488 & KF289307 & JF343735 \\
\hline P. capitalensis & LGMF 222 & Citrus sinensis & Brazil & KF206204 & KF206218 & JF261492 & KF289308 & JF343739 \\
\hline P. carissicola & CPC $25665^{\mathrm{T}}$ & Carissa macrocarpa & $\begin{array}{l}\text { South } \\
\text { Africa }\end{array}$ & KT950849 & KT950863 & KT950879 & KT950872 & KT950876 \\
\hline P. carochlae & CGMCC $3.17317^{\mathrm{T}}$ & Caryota ochlandra & China & K J847422 & - & KF289178 & KF289273 & KF289092 \\
\hline P. carochlae & CGMCC 3.17318 & Caryota ochlandra & China & KJ847423 & - & KJ847444 & KJ847430 & KJ847438 \\
\hline P. catimbauensis & URM $7672^{\mathrm{T}}$ & $\begin{array}{l}\text { Mandevilla } \\
\text { catimbauensis }\end{array}$ & Brazil & MF466160 & MF466163 & MF466155 & MF466157 & - \\
\hline P. catimbauensis & URM 7674 & $\begin{array}{l}\text { Mandevilla } \\
\text { catimbauensis }\end{array}$ & Brazil & MF466161 & MF466164 & MF466153 & MF466158 & - \\
\hline P. cavendishii & BRIP 57384 & Musa cv. Lady Finger & Australia & KC117644 & KU697330 & KF009695 & KF014059 & KU716085 \\
\hline P. cavendishii & BRIP 57383 & Musa cv. Lady Finger & Australia & KC117643 & KU697329 & KF009694 & KF014058 & KU716084 \\
\hline P. citriasiana & CBS $120486^{\mathrm{T}}$ & Citrus maxima & Thailand & FJ538360 & KF206314 & FJ538418 & FJ538476 & JF343686 \\
\hline P. citriasiana & CBS 120487 & Citrus maxima & China & FJ538361 & KF206313 & FJ538419 & FJ538477 & JF343687 \\
\hline P. citribraziliensis & CBS $100098^{\mathrm{T}}$ & Citrus limon & Brazil & FJ538352 & KF206221 & FJ538410 & FJ538468 & JF343691 \\
\hline P. citribraziliensis & СPC 17466 & Citrus sp. & Brazil & KF170302 & KF206261 & KF289226 & KF289282 & KF289161 \\
\hline P. citricarpa & CBS $127454^{\mathrm{T}}$ & Citrus limon & Australia & JF343583 & KF206306 & JF343604 & JF343667 & JF343771 \\
\hline P. citricarpa & CBS 127455 & Citrus sinensis & Australia & JF343584 & KF206305 & JF343605 & JF343668 & JF343772 \\
\hline P. citrichinaensis & ZJUCC $200956^{\mathrm{T}}$ & Citrus reticulata & China & JN791620 & - & JN791459 & JN791533 & - \\
\hline P. citrichinaensis & ZJUCC 2010150 & Citrus maxima & China & JN791662 & - & JN791514 & JN791582 & - \\
\hline P. citrimaxima & MFLUCC 10-0137 T & Citrus maxima & Thailand & KF170304 & KF206229 & KF289222 & KF289300 & KF289157 \\
\hline P. concentrica & CBS 937.70 & Hedera helix & Italy & FJ538350 & KF206291 & FJ538408 & KF289257 & JF411745 \\
\hline P. concentrica & CPC $18842^{\mathrm{T}}$ & Hedera sp. & Italy & KF170310 & KF206256 & KF289228 & KF289288 & KF289163 \\
\hline P. conjac & MUCC0410 & $\begin{array}{l}\text { Amorphophallus } \\
\text { rivieri }\end{array}$ & Japan & AB454342 & - & - & AB704239 & - \\
\hline P. cordylinophila & MFLUCC 10-0166 ${ }^{\mathrm{T}}$ & Cordyline fruticosa & Thailand & KF170287 & KF206242 & KF289172 & KF289295 & KF289076 \\
\hline P. cordylinophila & MFLUCC 12-0014 & Cordyline fruticosa & Thailand & KF170288 & KF206228 & KF289171 & KF289301 & KF289075 \\
\hline P. cornicola & CBS 111639 & Cornus florida & USA & KF170307 & - & - & KF289234 & - \\
\hline
\end{tabular}


Table 3 Continued.

\begin{tabular}{|c|c|c|c|c|c|c|c|c|}
\hline \multirow[t]{2}{*}{ Species } & \multirow{2}{*}{ Strain no.* } & \multirow{2}{*}{ Host } & \multirow[t]{2}{*}{ Country } & \multicolumn{5}{|c|}{ GenBank no. } \\
\hline & & & & ITS & LSU & ef1a & actin & gapdh \\
\hline P. cruenta & CBS 858.71 & $\begin{array}{l}\text { Polygonatum } \\
\text { odoratum }\end{array}$ & $\begin{array}{l}\text { Czech } \\
\text { Republic }\end{array}$ & MG934458 & - & MG934501 & MG934465 & MG934474 \\
\hline P. cruenta & MUCC0206 & $\begin{array}{l}\text { Polygonatum } \\
\text { odoratum var. } \\
\text { pluriflorum }\end{array}$ & Japan & AB454331 & - & - & AB704237 & - \\
\hline P. cryptomeriae & KACC 48643 & $\begin{array}{l}\text { Juniperus chinensis } \\
\text { var. sargentii }\end{array}$ & Not given & MK396559 & - & - & - & - \\
\hline P. cryptomeriae & MUCC0028 & Cryptomeria japonica & Japan & AB454271 & - & - & AB704213 & - \\
\hline P. cussonia & CPC $14873^{\mathrm{T}}$ & Cussonia sp. & $\begin{array}{l}\text { South } \\
\text { Africa }\end{array}$ & JF343578 & KF206279 & JF343599 & JF343662 & JF343764 \\
\hline P. cussonia & СРС 14875 & Cussonia sp. & $\begin{array}{l}\text { South } \\
\text { Africa }\end{array}$ & JF343579 & KF206278 & JF343600 & JF343663 & JF343765 \\
\hline P. elongata & CBS $126.22^{\mathrm{T}}$ & $\begin{array}{l}\text { Oxycoccus } \\
\text { macrocarpos }\end{array}$ & USA & FJ538353 & - & FJ538411 & FJ538469 & KF289164 \\
\hline P. ericarum & CBS $132534^{\mathrm{T}}$ & Erica gracilis & $\begin{array}{l}\text { South } \\
\text { Africa }\end{array}$ & KF206170 & KF206253 & KF289227 & KF289291 & KF289162 \\
\hline P. eugeniae & CBS $445.82^{\mathrm{T}}$ & Eugenia aromatica & Indonesia & AY042926 & KF206288 & KF289208 & KF289246 & KF289139 \\
\hline P. fallopiae & MUCC0113 ${ }^{\mathrm{T}}$ & Fallopia japonica & Japan & AB454307 & - & - & AB704228 & - \\
\hline P. fallopiae & ISOJ61 & - & Not given & MF164545 & - & - & - & - \\
\hline P. foliorum & CBS 174.77 & Cryptomeria japonica & USA & KF170308 & KF206290 & KF289200 & KF289245 & KF289131 \\
\hline P. foliorum & CBS $447.68^{\mathrm{T}}$ & Taxus baccata & Netherlands & KF170309 & KF206287 & KF289201 & KF289247 & KF289132 \\
\hline P. gardeniicola & MUCC0117 & Gardenia jasminoides & Japan & AB454310 & - & - & AB704230 & - \\
\hline P. gardeniicola & MUCC0089 & Gardenia jasminoides & Japan & AB454303 & - & - & - & - \\
\hline P. gaultheriae & CBS $447.70^{\mathrm{T}}$ & Gaultheria humifusa & USA & JN692543 & KF206298 & JN692531 & KF289248 & JN692508 \\
\hline P. hagahagaensis & CBS $144592^{\mathrm{T}}$ & Carissa bispinosa & $\begin{array}{l}\text { South } \\
\text { Africa }\end{array}$ & MK442614 & MK442550 & MK442705 & MK442641 & MK442657 \\
\hline P. hakeicola & CBS $143492^{\mathrm{T}}$ & Hakea sp. & Australia & MH107907 & MH107953 & MH108025 & MH107984 & MH107999 \\
\hline P. hamamelidis & MUCC149 & Hamamelis japonica & Japan & KF170289 & - & - & KF289309 & - \\
\hline P. harai & MUCC0038 & Aucuba japonica & Japan & AB454277 & - & - & AB704218 & - \\
\hline P. harai & MUCC0043 & Aucuba japonica & Japan & AB454281 & - & - & AB704219 & - \\
\hline P. hostae & CGMCC $3.14355^{\mathrm{T}}$ & Hosta plantaginea & China & JN692535 & - & JN692523 & JN692511 & JN692503 \\
\hline
\end{tabular}


Table 3 Continued.

\begin{tabular}{|c|c|c|c|c|c|c|c|c|}
\hline \multirow[t]{2}{*}{ Species } & \multirow{2}{*}{ Strain no.* } & \multirow[t]{2}{*}{ Host } & \multirow[t]{2}{*}{ Country } & \multicolumn{5}{|c|}{ GenBank no. } \\
\hline & & & & ITS & LSU & efla & actin & gapdh \\
\hline P. hostae & CGMCC 3.14356 & Hosta plantaginea & China & JN692536 & - & JN692524 & JN692512 & JN692504 \\
\hline P. hubeiensis & CGMCC $3.14986^{\mathrm{T}}$ & $\begin{array}{l}\text { Viburnum } \\
\text { odoratissimim }\end{array}$ & China & JX025037 & - & JX025042 & JX025032 & JX025027 \\
\hline P. hubeiensis & CGMCC 3.14987 & $\begin{array}{l}\text { Viburnum } \\
\text { odoratissimim }\end{array}$ & China & JX025038 & - & JX025043 & JX025033 & JX025028 \\
\hline P. hymenocallidicola & CBS $131309^{\mathrm{T}}$ & $\begin{array}{l}\text { Hymenocallis } \\
\text { littoralis }\end{array}$ & Australia & JQ044423 & JQ044443 & KF289211 & KF289242 & KF289142 \\
\hline P. hymenocallidicola & СРC 19331 & $\begin{array}{l}\text { Hymenocallis } \\
\text { littoralis }\end{array}$ & Australia & KF170303 & KF206254 & KF289212 & KF289290 & KF289143 \\
\hline P. hypoglossi & CBS 101.72 & Ruscus aculeatus & Italy & FJ538365 & KF206326 & FJ538423 & FJ538481 & JF343694 \\
\hline P. hypoglossi & CBS $434.92^{\mathrm{T}}$ & Ruscus aculeatus & Italy & FJ538367 & KF206299 & FJ538425 & FJ538483 & JF343695 \\
\hline $\begin{array}{l}P . \text { ilicis-aquifolii- } \\
\text { aquifolii }\end{array}$ & CGMCC $3.14358^{\mathrm{T}}$ & Ilex aquifolium & China & JN692538 & - & JN692526 & JN692514 & - \\
\hline $\begin{array}{l}\text { P. ilicis-aquifolii- } \\
\text { aquifolii }\end{array}$ & CGMCC 3.14359 & Ilex aquifolium & China & JN692539 & - & JN692527 & JN692515 & - \\
\hline P. illicii & $24-1-1^{\mathrm{T}}$ & Illicium verum & China & MF198235 & MF198240 & MF198237 & MF198243 & - \\
\hline P. illicii & $16-16-1$ & Illicium verum & China & MF198234 & MF198239 & MF198236 & MF198242 & - \\
\hline P. iridigena & CBS $143410^{\mathrm{T}}$ & Iris sp. & $\begin{array}{l}\text { South } \\
\text { Africa }\end{array}$ & MG934459 & - & MG934502 & MG934466 & - \\
\hline P. kerriae & MAFF $240047^{\mathrm{T}}$ & Kerria japonica & Japan & AB454266 & - & - & - & - \\
\hline P. kobus & MUCC0049 & Magnolia kobus & Japan & AB454286 & - & - & AB704221 & - \\
\hline P. leucothoicola & MUCC553 T & Leucothoe catesbaei & Japan & AB454370 & AB454370 & - & KF289310 & - \\
\hline P. ligustricola & MUCC0024 $^{\mathrm{T}}$ & $\begin{array}{l}\text { Ligustrum } \\
\text { obtusifolium }\end{array}$ & Japan & AB454269 & - & - & AB704212 & - \\
\hline P. maculata & CPC $18347^{\mathrm{T}}$ & $\begin{array}{l}\text { Musa cv. Golygoly } \\
\text { pot-pot }\end{array}$ & Australia & JQ743570 & - & KF009700 & KF014016 & - \\
\hline P. maculata & BRIP 46622 & $\begin{array}{l}\text { Musa cv. Golygoly } \\
\text { pot-pot }\end{array}$ & Australia & JQ743567 & - & KF009692 & KF014013 & - \\
\hline P. mangiferae & IMI $260576^{\mathrm{T}}$ & Mangifera indica & India & JF261459 & KF206222 & JF261501 & JF343641 & JF343748 \\
\hline P. mangiferae & СРC 20260 & Arecaceae & Thailand & KF206193 & KF206243 & KF289187 & KF289294 & KF289114 \\
\hline P. mangifera-indicae & MFLUCC 10-0029 T & Mangifera indica & Thailand & KF170305 & KF206240 & KF289190 & KF289296 & KF289121 \\
\hline
\end{tabular}


Table 3 Continued.

\begin{tabular}{|c|c|c|c|c|c|c|c|c|}
\hline \multirow[t]{2}{*}{ Species } & \multirow{2}{*}{ Strain no.* } & \multirow[t]{2}{*}{ Host } & \multirow[t]{2}{*}{ Country } & \multicolumn{5}{|c|}{ GenBank no. } \\
\hline & & & & ITS & LSU & ef1a & actin & gapdh \\
\hline P. mimusopisicola & CBS $138899^{\mathrm{T}}$ & Mimusops zeyheri & $\begin{array}{l}\text { South } \\
\text { Africa }\end{array}$ & KP004447 & MH878626 & - & - & - \\
\hline P. minima & CBS $585.84^{\mathrm{T}}$ & Acer rubrum & USA & KF206176 & KF206286 & KF289204 & KF289249 & KF289135 \\
\hline P. miurae & MUCC0065 & Lindera praecox & Japan & AB454291 & - & - & AB704224 & - \\
\hline P. musaechinensis & GZAAS 6.1247 & Musa.sp. & China & KF955294 & - & KM816639 & KM816627 & KM816633 \\
\hline P. musaechinensis & GZAAS 6.1384 & Musa.sp. & China & KF955295 & - & KM816640 & KM816628 & KM816634 \\
\hline P. musarum & BRIP 57803 & Musa sp & Malaysia & JX997138 & - & KF009737 & KF014055 & - \\
\hline P. musarum & BRIP 58028 & Musa sp & Australia & КС988377 & - & KF009738 & KF014054 & - \\
\hline P. neopyrolae & CPC $21879^{\mathrm{T}}$ & Pyrola asarifolia & Japan & AB454318 & AB454318 & - & AB704233 & - \\
\hline P. ophiopogonis & KACC 47754 & $\begin{array}{l}\text { Ophiopogon } \\
\text { japonicus }\end{array}$ & South Korea & KP197057 & - & - & - & - \\
\hline P. ophiopogonis & LrLF11 & $\begin{array}{l}\text { Leaf of Lycoris } \\
\text { radiata }\end{array}$ & China & MG543713 & - & - & - & - \\
\hline P. owaniana & CBS $776.97^{\mathrm{T}}$ & $\begin{array}{l}\text { Brabejum } \\
\text { stellatifolium }\end{array}$ & $\begin{array}{l}\text { South } \\
\text { Africa }\end{array}$ & FJ538368 & KF206293 & FJ538426 & KF289254 & JF343767 \\
\hline P. owaniana & СРС 14901 & $\begin{array}{l}\text { Brabejum } \\
\text { stellatifolium }\end{array}$ & $\begin{array}{l}\text { South } \\
\text { Africa }\end{array}$ & JF261462 & KF206303 & JF261504 & KF289243 & JF343766 \\
\hline P. pachysandricola & MUCC124 ${ }^{\mathrm{T}}$ & $\begin{array}{l}\text { Pachysandra } \\
\text { terminalis }\end{array}$ & Japan & AB454317 & AB454317 & - & AB704232 & - \\
\hline P. paracapitalensis & CPC $26517^{\mathrm{T}}$ & Citrus floridana & Italy & KY855622 & KY855796 & KY855951 & KY855677 & KY855735 \\
\hline P. paracapitalensis & СРC 26518 & Citrus floridana & Italy & KY855623 & KY855797 & KY855952 & KY855678 & KY855736 \\
\hline P. paracapitalensis & CPC 26700 & Citrus floridana & Italy & KY855624 & KY855798 & KY855953 & KY855679 & KY855737 \\
\hline P. paracapitalensis & СРC 26701 & Citrus floridana & Italy & KY855625 & KY855799 & KY855954 & KY855680 & KY855738 \\
\hline P. paracapitalensis & CPC 26805 & Citrus floridana & Italy & KY855626 & KY855800 & KY855955 & KY855681 & KY855739 \\
\hline P. paracapitalensis & CPC 26806 & Citrus floridana & Italy & KY855627 & KY855801 & KY855956 & KY855682 & KY855740 \\
\hline P. paracapitalensis & CPC 28120 & Citrus limon & Spain & KY855628 & KY855802 & KY855957 & KY855683 & KY855741 \\
\hline P. paracapitalensis & СРС 28121 & Citrus limon & Spain & KY855629 & KY855803 & KY855958 & KY855684 & KY855742 \\
\hline P. paracapitalensis & СРC 28122 & Citrus limon & Spain & KY855630 & KY855804 & KY855959 & KY855685 & KY855743 \\
\hline P. paracapitalensis & СРС 28123 & Citrus limon & Spain & KY855631 & KY855805 & KY855960 & KY855686 & KY855744 \\
\hline$P$. paracapitalensis & СРС 28127 & Citrus limon & Spain & KY855632 & KY855806 & KY855961 & KY855687 & KY855745 \\
\hline
\end{tabular}


Table 3 Continued.

\begin{tabular}{|c|c|c|c|c|c|c|c|c|}
\hline \multirow[t]{2}{*}{ Species } & \multirow[t]{2}{*}{ Strain no.* } & \multirow[t]{2}{*}{ Host } & \multirow[t]{2}{*}{ Country } & \multicolumn{5}{|c|}{ GenBank no. } \\
\hline & & & & ITS & LSU & ef1a & actin & gapdh \\
\hline P. paracapitalensis & CPC 28128 & Citrus limon & Spain & KY855633 & KY855807 & KY855962 & KY855688 & KY855746 \\
\hline P. paracapitalensis & СРС 28129 & Citrus limon & Spain & KY855634 & KY855808 & KY855963 & KY855689 & KY855747 \\
\hline P. paracitricarpa & CPC $27169^{\mathrm{T}}$ & Citrus limon & Greece & KY855635 & KY855809 & KY855964 & KY855690 & KY855748 \\
\hline P. paracitricarpa & ZJUCC 200933 & Citrus sinensis & China & JN791626 & KY855813 & JN791468 & JN791544 & KY855752 \\
\hline P. parthenocissi & CBS $111645^{\mathrm{T}}$ & $\begin{array}{l}\text { Parthenocissus } \\
\text { quinquefolia }\end{array}$ & USA & EU683672 & - & JN692530 & JN692518 & - \\
\hline P. partricuspidatae & NBRC $9466^{\mathrm{T}}$ & $\begin{array}{l}\text { Parthenocissus } \\
\text { tricuspidata }\end{array}$ & Japan & KJ847424 & - & KJ847446 & KJ847432 & KJ847440 \\
\hline P. partricuspidatae & NBRC 9757 & $\begin{array}{l}\text { Parthenocissus } \\
\text { tricuspidata }\end{array}$ & Japan & KJ847425 & - & KJ847447 & KJ847433 & KJ847441 \\
\hline P. paxistimae & CBS $112527^{\mathrm{T}}$ & Paxistima mysinites & USA & KF206172 & KF206320 & KF289209 & KF289239 & KF289140 \\
\hline P. philoprina & CBS 587.69 & Ilex aquifolium & Spain & KF154278 & KF206297 & KF289206 & KF289250 & KF289137 \\
\hline P. philoprina & CBS 616.72 & Ilex aquifolium & Germany & KF154279 & KF206296 & KF289205 & KF289251 & KF289136 \\
\hline P. podocarpi & CBS 111646 & Podocarpus falcatus & $\begin{array}{l}\text { South } \\
\text { Africa }\end{array}$ & AF312013 & KF206323 & KC357671 & KC357670 & KF289169 \\
\hline P. podocarpi & CBS 111647 & $\begin{array}{l}\text { Podocarpus } \\
\text { lanceolata }\end{array}$ & $\begin{array}{l}\text { South } \\
\text { Africa }\end{array}$ & KF154276 & KF206322 & KF289232 & KF289235 & KF289168 \\
\hline P. podocarpicola & CBS $728.79^{\mathrm{T}}$ & Podocarpus maki & USA & KF206173 & KF206295 & KF289203 & KF289252 & KF289134 \\
\hline P. pseudotsugae & CBS 111649 & $\begin{array}{l}\text { Pseudotsuga } \\
\text { menziesii }\end{array}$ & USA & KF154277 & KF206321 & KF289231 & KF289236 & KF289167 \\
\hline P. pyrolae & IFO 32652 & Erica carnea & Not given & АВ041242 & - & - & - & - \\
\hline P. rhizophorae & CPC 20508 & Ixora chinensis & Thailand & KF206198 & KF206225 & KF289185 & KF289302 & KF289111 \\
\hline P. rhizophorae & СРC 20509 & Cordyline fruticosa & Thailand & KF206199 & KF206224 & KF289186 & KF289303 & KF289112 \\
\hline P. rhizophorae & NCYUCC 19-0352 ${ }^{\mathrm{T}}$ & Rhizophora stylosa & Taiwan & MT360030 & МT360039 & - & МT363248 & MT363250 \\
\hline P. rhizophorae & NCYUCC 19-0358 & Rhizophora stylosa & Taiwan & МТ360031 & МТ360040 & - & МТ363249 & MT363250 \\
\hline P. rhodorae & CBS 901.69 & Rhododendron sp. & Netherlands & KF206174 & KF206292 & KF289230 & KF289256 & KF289166 \\
\hline P. rubella & CBS $111635^{\mathrm{T}}$ & Acer rubrum & USA & KF206171 & EU754194 & KF289198 & KF289233 & KF289129 \\
\hline P. schimae & CGMCC $3.14354^{\mathrm{T}}$ & Schima superba & China & JN692534 & - & JN692522 & JN692510 & JN692506 \\
\hline P. schimicola & CGMCC $3.17319^{\mathrm{T}}$ & Schima superba & China & KJ847426 & - & KJ847448 & KJ847434 & KJ854895 \\
\hline P. schimicola & CGMCC 3.17320 & Schima superba & China & KJ847427 & - & KJ847449 & KJ847435 & KJ854896 \\
\hline
\end{tabular}


Table 3 Continued.

\begin{tabular}{|c|c|c|c|c|c|c|c|c|}
\hline \multirow[t]{2}{*}{ Species } & \multirow[t]{2}{*}{ Strain no.* } & \multirow[t]{2}{*}{ Host } & \multirow[t]{2}{*}{ Country } & \multicolumn{5}{|c|}{ GenBank no. } \\
\hline & & & & ITS & LSU & efla & actin & gapdh \\
\hline P. speewahensis & BRIP $58044^{\mathrm{T}}$ & Orchids & Australia & KF017269 & - & KF017268 & - & - \\
\hline P. sphaeropsoidea & CBS 756.70 & $\begin{array}{l}\text { Aesculus } \\
\text { hippocastanum }\end{array}$ & Germany & AY042934 & KF206294 & KF289202 & KF289253 & KF289133 \\
\hline P. spinarum & CBS 292.90 & $\begin{array}{l}\text { Chamaecyparis } \\
\text { pisifera }\end{array}$ & France & JF343585 & KF206301 & JF343606 & JF343669 & JF343773 \\
\hline P. styracicola & CGMCC3.14985 T & Styrax grandiflorus & China & JX025040 & - & JX025045 & JX025035 & JX025030 \\
\hline P. styracicola & CGMCC3.14989 & Styrax grandiflorus & China & JX025041 & - & JX025046 & JX025036 & JX025031 \\
\hline P. telopeae & CBS $777.97^{\mathrm{T}}$ & $\begin{array}{l}\text { Telopea } \\
\text { speciosissima }\end{array}$ & Tasmania & KF206205 & KF206285 & KF289210 & KF289255 & KF289141 \\
\hline P. vaccinii & ATCC $46255^{\mathrm{T}}$ & $\begin{array}{l}\text { Vaccinium } \\
\text { macrocarpon }\end{array}$ & - & KC193585 & - & KC193582 & KC193580 & KC193583 \\
\hline P. vaccinii & LC 2795 & Vitis macrocarpon & USA & KR233323 & - & - & - & - \\
\hline P. vacciniicola & CPC $18590^{\mathrm{T}}$ & $\begin{array}{l}\text { Vaccinium } \\
\text { macrocarpum }\end{array}$ & USA & KF170312 & KF206257 & KF289229 & KF289287 & KF289165 \\
\hline P. vitis-rotundifoliae & CGMCC $3.17322^{\mathrm{T}}$ & Vitis rotundifolia & USA & KJ847428 & - & KJ847450 & KJ847436 & KJ847442 \\
\hline P. vitis-rotundifoliae & CGMCC 3.17321 & Vitis rotundifolia & USA & KJ847429 & - & KJ847451 & KJ847437 & KJ847443 \\
\hline P. yuccae & CBS 112065 & Yucca elephantipes & USA & KF206175 & - & - & KF289237 & - \\
\hline P. yuccae & CBS 117136 & Yucca elephantipes & $\begin{array}{l}\text { New } \\
\text { Zealand }\end{array}$ & JN692541 & KF766385 & JN692529 & JN692517 & JN692507 \\
\hline Phyllosticta sp. & СРC 11336 & Eucalyptus globulus & Spain & KF206177 & KF206284 & KF289199 & KF289258 & KF289130 \\
\hline Phyllosticta sp. & MUCC147 & $\begin{array}{l}\text { Rhododendron } \\
\text { keiskei }\end{array}$ & Japan & AB454319 & AB454319 & - & AB704234 & - \\
\hline Phyllosticta sp. & CPC 20269 & $\begin{array}{l}\text { Ophiopogon } \\
\text { japonicus }\end{array}$ & Thailand & KC291344 & KF206235 & KC342564 & КС342541 & KF289118 \\
\hline Phyllosticta sp. & CBS 173.77 & Citrus aurantiifolia & $\begin{array}{l}\text { New } \\
\text { Zealand }\end{array}$ & KF206179 & KF306231 & FJ538393 & KF289244 & KF289100 \\
\hline Phyllosticta sp. & CBS 123404 & Musa paradisiaca & Thailand & FJ538333 & JQ743601 & FJ538391 & FJ538449 & KF289095 \\
\hline Phyllosticta sp. & СРС 17748 & Heliconia sp. & Thailand & KF206190 & KF206258 & KF289180 & KF289286 & KF289096 \\
\hline Phyllosticta sp. & СРC 20252 & Punica granatum & Thailand & KC291334 & KF206251 & KC342554 & КС342531 & KF289097 \\
\hline Phyllosticta sp. & CBS 119720 & Musa acuminata & USA & KF206178 & KF206316 & FJ538398 & KF289240 & KF289098 \\
\hline
\end{tabular}


Phylogenetic analysis using ITS (479 bp) - most species clades were recovered as in the combined gene tree, except for Phyllosticta mimusopisicola, which grouped within P. capitalensis species complex (Supplementary Fig. 1).

Phylogenetic analysis using LSU (763 bp) - species complex clades of $P$. rhodorae and $P$. vaccinii clustered within the $P$. capitalensis species complex. Some members of $P$. cruenta species complex clustered within the $P$. capitalensis species complex. Phyllosticta concentrica species complex clade was a well-resolved clade and sister to a clade consisting of the $P$. capitalensis, $P$. cruenta, $P$. vaccinii, and $P$. rhodorae species complexes. Phyllosticta owaniana species complex was paraphyletic (Supplementary Fig. 2).

Phylogenetic analysis using efl $\alpha$ (285 bp) - most species in P. capitalensis species complex clustered together, except for $P$. brazilianiae, $P$. ilicis-aquifolii, $P$. philoprina, $P$. brazilianiae, and $P$. mangifera-indicae. Species grouping in $P$. cruenta species complex were dispersed throughout the tree, and clustered with species from other clades. Members of clades $P$. concentrica, $P$. owaniana, P. rhodorae, and P. vaccinii formed a well-resolved cluster (Supplementary Fig. 3).

Phylogenetic analysis using actin (223 bp) $-P$. capitalensis species complex was recovered as in the combined gene tree and included species of $P$. vaccinii species complex (P. vaccinii, and $P$. vacciniicola). The $P$. rhodorae, $P$. concentrica, and $P$. owaniana species complexes were wellresolved and clustered together. Species of $P$. cruenta species complex did not cluster together (Supplementary Fig. 4).

Phylogenetic analysis using gapdh (623 bp) - Members of $P$. capitalensis species complex dispersed in the tree. However, Phyllosticta capitalensis, $P$. paracapitalensis, and $P$. rhizophorae clustered within the same clade as in other single gene trees. Phyllosticta cruenta species complex was paraphyletic with some species grouping with $P$. capitalensis species complex ( $P$. folliorum), $P$. vaccinii species complex ( $P$. vaccinii, and $P$. vacciniicola) and $P$. rhodorae species complex $(P$. rhodorae). Phyllosticta podocarpicola did not cluster within the clade. Phyllosticta concentrica species complex formed a well-resolved clade (Supplementary Fig. 5).

Phylogenetic analysis using the five-gene combined dataset 1 - consisted of 195 strains and Botryosphaeria obtusa (CMW 8232) and B. stevensii (CBS 112553) sequences were used as outgroup. The total length of the dataset was 2373 characters including alignment gaps, ITS1+ITS2: 1-321, 5.8S: 322-479, LSU: 480-1242, efl $\alpha$ (exon): 1243-1296, actin (exon): 12971372, gapdh: 1373-1995, efl $\alpha$ (intron): 1996-2226, and actin (intron): 2227-2373. The combined dataset contained 1493 constant, 156 parsimony uninformative and 724 parsimony informative characters. The combined dataset was analyzed using MP, ML and BI. The trees generated under different optimality criteria were similar in topology and did not differ (data not shown). Descriptive statistics generated from MP analysis based on the combined dataset were TL $=3451$, $\mathrm{CI}=0.402, \mathrm{RI}=0.839, \mathrm{RC}=0.337, \mathrm{HI}=0.598$. The best scoring likelihood tree for the combined dataset had a final value of -20730.513137 (Fig. 1). The new species grouped within $P$. capitalensis species complex clade along with two other sequences that are denoted as $P$. capitalensis in GenBank. Statistical support for the $P$. capitalensis species complex was 52\% ML/0.94 PP. Maximum parsimony (MP), maximum likelihood (ML) and Bayesian inference analysis (BI) of five loci produced a phylogenetic tree that contained six supported clades (Fig. 1). This study proposes to place all currently and newly described species clades of Phyllosticta to six species complexes based on molecular phylogenetic analyses of ITS, LSU, efl $\alpha$, actin and gapdh loci as follows: 1) Phyllosticta capitalensis species complex consisted of 27 species, 2) Phyllosticta cruenta species complex comprised 21 species (74\% ML /0.94 PP), 3) Phyllosticta vaccinii species complex comprised two species (67\% MP/ 84\% ML/ 0.99 PP), 4) Phyllosticta rhodorae species complex consisted of two species and an unnamed species (61\% ML/0.96 PP), 5) Phyllosticta concentrica species complex included 25 species and was strongly supported (96\% MP/ 99\% ML/1.0 PP) and 6) Phyllosticta owaniana species complex included six species and was strongly supported (100\% MP/ 99\% ML/1.0 PP).

Phylogenetic analysis using five-gene combined dataset 2 - constructed using the 74 strains from $P$. capitalensis species complex and Phyllosticta cordylinophila sequences (MFLUCC 10- 
0166 and MFLUCC 12-0014) were used as outgroup taxa. The total length of the dataset was 2434 characters including alignment gaps, ITS1+ITS2: 1-392, 5.8S: 393-550, LSU: 551-1382, ef1 $\alpha$ (exon): 1383-1417, actin (exon): 1418-1527, gapdh: 1528-2150, efl $\alpha$ (intron): 2151-2349, and actin (intron): 2350-2496 (Fig. 2). The combined dataset contained 2357 constant, 50 parsimony uninformative and 89 parsimony informative characters. The combined dataset was analyzed using MP, ML and BI. The trees generated under different optimality criteria were similar in topology and did not differ (data not shown). Descriptive statistics generated from MP analysis based on the combined dataset were $\mathrm{TL}=167, \mathrm{CI}=0.850, \mathrm{RI}=0.930, \mathrm{RC}=0.791, \mathrm{HI}=0.150$. The best scoring likelihood tree selected for the combined dataset had a final value of -4603.349843 (Fig. 2).

Phyllosticta paracapitalensis formed a species clade, including the ex-type sequence data (CPC 26517). Phyllosticta paracapitalensis species were sister to the Phyllosticta capitalensis sensu stricto, within $P$. capitalensis species complex clade based on single-locus and combined gene trees (Figs 1, 2, Supplementary Figs 1-5). Phyllosticta capitalensis strains CBS 173.77 and CBS 119720 formed a separate clade from the other strains of $P$. capitalensis and $P$. paracapitalensis (Figs 1, 2). Nucleotide polymorphism comparisons of $P$. capitalensis (CBS 128856, ex-type) and P. paracapitalensis (CPC 26517, ex-type) with strain CBS 173.77 showed the following differences: $2 \mathrm{bp}$ ITS, $4 \mathrm{bp}$ efl $\alpha$, 3bp actin and 0bp gapdh between $P$. capitalensis and CBS 173.77; and 4bp ITS, 1bp efla, 0bp actin and 2bp gapdh between P. paracapitalensis and CBS 173.77. CBS 119720 has 0bp ITS, 4bp efl $\alpha$, 3bp actin and 0bp gapdh differences from $P$. capitalensis, and 2bp ITS, 1bp efl $\alpha$, 0bp actin and 2bp gapdh differences from $P$. paracapitalensis. Hence, these two strains could be unnamed species of Phyllosticta rather than $P$. paracapitalensis. However, because there are no intervening species, these twostrains could also be divergent of $P$. paracapitalensis. Additional data are needed to definitively resolve this issue.

Phyllosticta camelliae strain MUCC0059 and P. fallopiae strain ISOJ61 have unstable placements in the phylogenetic trees (Figs 1, 2). Based on the polymorphic nucleotide comparison of ITS, efl $\alpha$, actin and gapdh with P. capitalensis (CBS 128856, ex-type) and P. paracapitalensis (CPC 26517, ex-type), strain ISOJ61 has 2bp ITS differences from $P$. paracapitalensis, and 0bp ITS differences from P. capitalensis. The strain MUCC0059 has 1bp ITS and 0bp actin differences from $P$. capitalensis, and 3bp ITS and 5bp actin differences from P. paracapitalensis. However, more DNA sequence data are needed for future study to resolve those problematic strains.

Phyllosticta capitalensis sequences formed a large cluster in the tree, which included the extype strain (CBS 128856). The newly described taxa (NCYUCC 19-0352 and NCYUCC 19-0358) formed a distinct clade, which grouped with P. capilalensis (CPC 20508 and CPC 20509) (Figs 1, 2). The strains CPC 20508 and CPC 20509 were synonymized under the new species based on phylogenetic analysis and nucleotide comparisons of ITS, efl $\alpha$, actin and gapdh. Strain CPC 20508 has 2bp ITS, 0bp efl $\alpha$, 3bp actin, 0bp gapdh differences from P. capitalensis (CBS 128856, extype) and 4 bp ITS, 5bp efl $\alpha$, 2bp actin, 2bp gapdh differences from $P$. paracapitalensis (CPC 26517, ex-type). Strain CPC 20509 has 2 bp ITS, 0bp efl $\alpha$, 3bp actin, 0bp gapdh differences from $P$. capitalensis (CBS 128856, ex-type), and 4 bp ITS, 5bp efla, 2bp actin, 2bp gapdh differences from $P$. paracapitalensis (CPC 26517, ex-type). Three strains previously named as $P$. capitalensis (CBS 123404, CPC 20252, CPC 17748) are proposed as unnamed species based on phylogenetic analysis (Figs 1, 2) and nucleotide comparisons of ITS, efl $\alpha$, actin and gapdh with the ex-type of $P$. capitalensis (CBS 128856) and P. paracapitalensis (strain CBS 123404). Strain CBS 123404 has 0bp ITS, 1bp efl $\alpha$, 3bp actin, 3bp gapdh differences from $P$. capitalensis, and 2bp ITS, 4bp efl $\alpha$, 2bp actin, 5bp gapdh from P. paracapitalensis; CPC 17748 has 0bp ITS, 1bp efl $\alpha$, 3bp actin, 4bp gapdh differences from $P$. capitalensis, and 2bp ITS, 4bp efl $\alpha$, 2bp actin, 6bp gapdh from $P$. paracapitalensis; CPC 20252 has 1 bp ITS, 0bp efla, 3bp actin, 0bp gapdh differences from $P$. capitalensis, and 3bp ITS, 5bp efla, 2bp actin, 2bp gapdh differed from $P$. paracapitalensis. Phyllosticta capitalensis strain CPC 20269 formed a distinct lineage from other strains of $P$. capitalensis with high bootstrap support (Fig. 2). It has 4bp ITS, 7bp efl $\alpha$, 5bp actin, and 2bp gapdh differences from P. paracapitalensis (CPC 26517, ex-type), and 2bp ITS, 2bp efla, 6bp actin, and 0bp gapdh differences from $P$. capitalensis (CBS 128856, ex-type). Hence, we leave it as 
an unnamed species based on phylogenetic analysis. Nonetheless, in the figure 1 , the sequence grouped in a different position, thus further analysis with additional phylogenetic markers is needed to determine exact placement.

\section{Taxonomy}

\section{Phyllostictaceae}

See Hongsanan et al. (2020) and Wikee et al. (2013b) for descriptions and illustrations.

\section{Phyllosticta Pers.}

For genus description see Wikee et al. (2013b) and Hongsanan et al. (2020). Herein we introduce six species complexes (Phyllosticta capitalensis, P. concentrica, P. cruenta, P. owaniana, $P$. rhodorae, and $P$. vaccinii), which form distinct clades.

\section{Phyllosticta capitalensis species complex}

Species included in Phyllosticta capitalensis species complex - P. acaciigena, P. aloeicola, P. ardisiicola, P. aristolochiicola, $P$. azevinhi, P. beaumarisii, $P$. brazilianiae, $P$. capitalensis, $P$. carochlae, P. cavendishii, P. cordylinophila, P. eugeniae, P. fallopiae, P. ilicis-aquifolii, P. maculata, $P$. mangiferae, $P$. mangifera-indicae, $P$. musaechinensis, $P$. musarum, $P$. paracapitalensis, $P$. parthenocissi, $P$. partricuspidatae, $P$. philoprina, $P$. rhizophorae, $P$. schimae, P. schimicola, $P$. styracicola, $P$. vitis-rotundifoliae.

Notes - 28 species are included in Phyllosticta capitalensis species complex based on molecular analyses and morphological characters. Members of this section are mostly reported as pathogenic and endophytic fungi from a broad range of hosts (Supplementary Table 1). Species of this complex are characterized by conidia that are ellipsoid or ellipsoid to obovoid, ovoid, obpyriform with a mucoid sheath with apical mucoid appendage; ascospores are limoniform with obtuse ends, with distinct hyaline gelatinous caps at both ends, (Supplementary Table 2). Sexual morphs of six species have been reported in this group ( $P$. cavendishii, $P$. maculata, P. musarum, $P$. paracapitalensis, $P$. philoprina, and $P$. rhizophorae). Phyllosticta capitalensis and $P$. azevinhi, most wildly distributed species of Phyllosticta was included here. This species complex is recovered in the multilocus tree, as well as in the single locus ITS and actin trees (Fig. 1, Supplementary Figs 1, 4). Phyllosticta capitalensis is used to describe this species complex name based on publication year.

Hennings (1908) described Phyllosticta capitalensis on Stanhopea sp. (Orchidaceae) from Brazil. The species is commonly isolated as an endophyte and has worldwide distribution (Glienke-Blanco et al. 2002, Silva \& Pereira 2007, Silva et al. 2008, Rashmi et al. 2019). Wikee et al. (2013a) reported that $P$. capitalensis was found in more than 70 plant families. Many factors affect host infection with $P$. capitalensis, such as environmental conditions, host and non-host organisms, and plant defence mechanisms (Wikee et al. 2013a). Guarnaccia et al. (2017) introduced Phyllosticta paracapitalensis from asymptomatic living leaves of Citrus sp. from Italy. Phyllosticta paracapitalensis is sister species to $P$. capitalensis based on molecular analyses of ITS, act, ef1 $\alpha$, gapdh, LSU and rpb2 (Guarnaccia et al. 2017).

\section{Phyllosticta concentrica species complex}

Species included in the Phyllosticta concentrica species complex $-P$. aspidistricola, $P$. aucubae-japonicae, $P$. bifrenariae, $P$. catimbauensis, $P$. citriasiana, $P$. citribrasiliensis, $P$. citricarpa, P. citrichinensis, P. citri-maxima, P. concentrica, P. cussonia, P. elongata, P. ericarum, P. gardeniicola, P. harai, P. hostae, P. hymenocallidicola, P. hypoglossi, P. iridigena, $P$. kerriae, $P$. kobus, $P$. ophiopogonis, $P$. paracitricarpa, $P$. speewahensis, $P$. spinarum. 


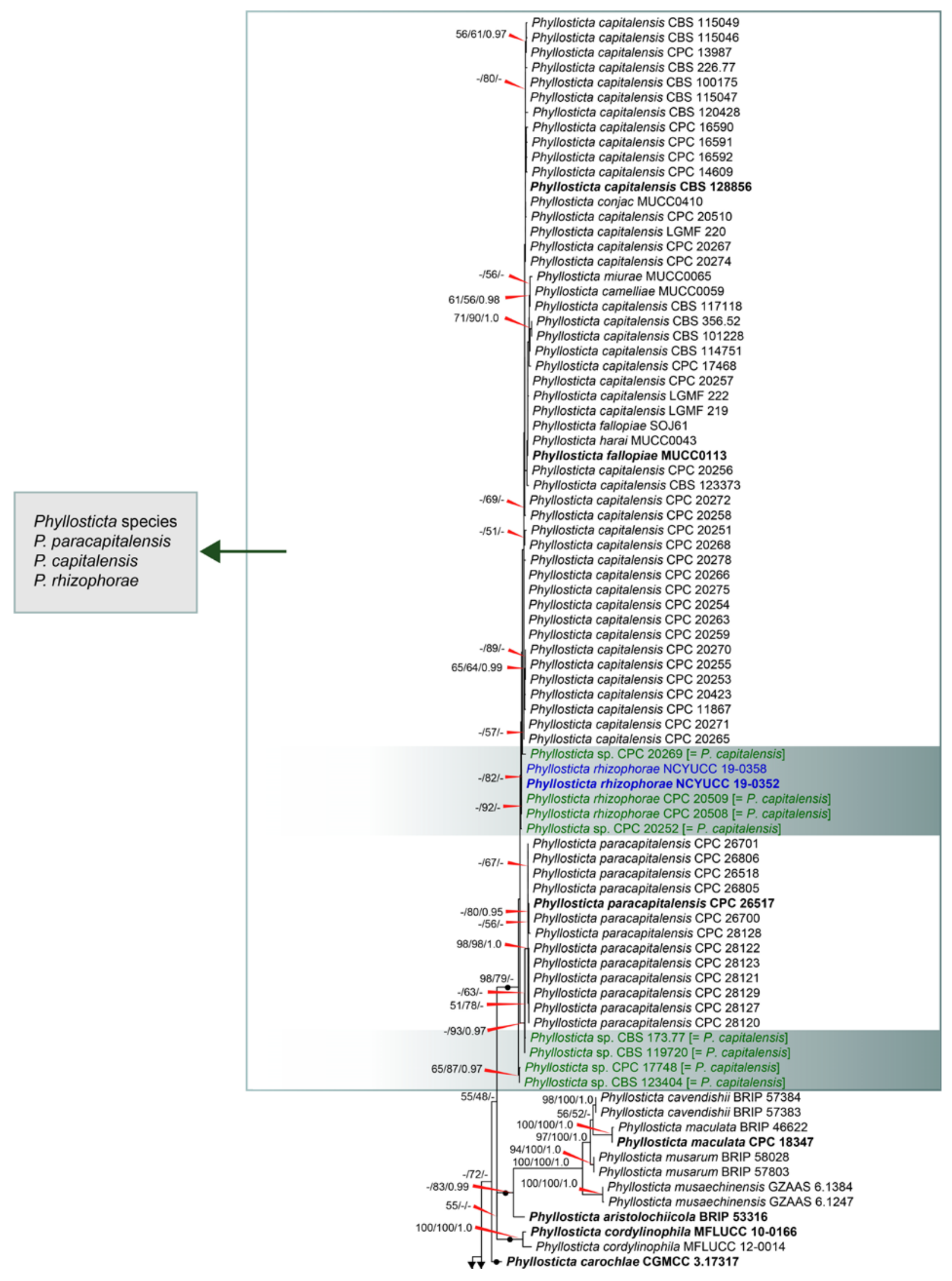

Figure 1 - Maximum likelihood phylogenetic tree inferred from combined ITS, LSU, efl $\alpha$, actin and gapdh sequence data from 195 strains of the genus Phyllosticta. The tree is artificially rooted to Botryosphaeria obtusa strain CMW 8232 and B. stevensii strain CBS 112553. Maximum parsimony and maximum likelihood bootstrap values $\leq 50 \%$, and Bayesian posterior probabilities $\leq 0.90$ are given at the nodes in this order. The species obtained in this study are in blue and species synonymized are in green. Ex-type taxa are in bold. 


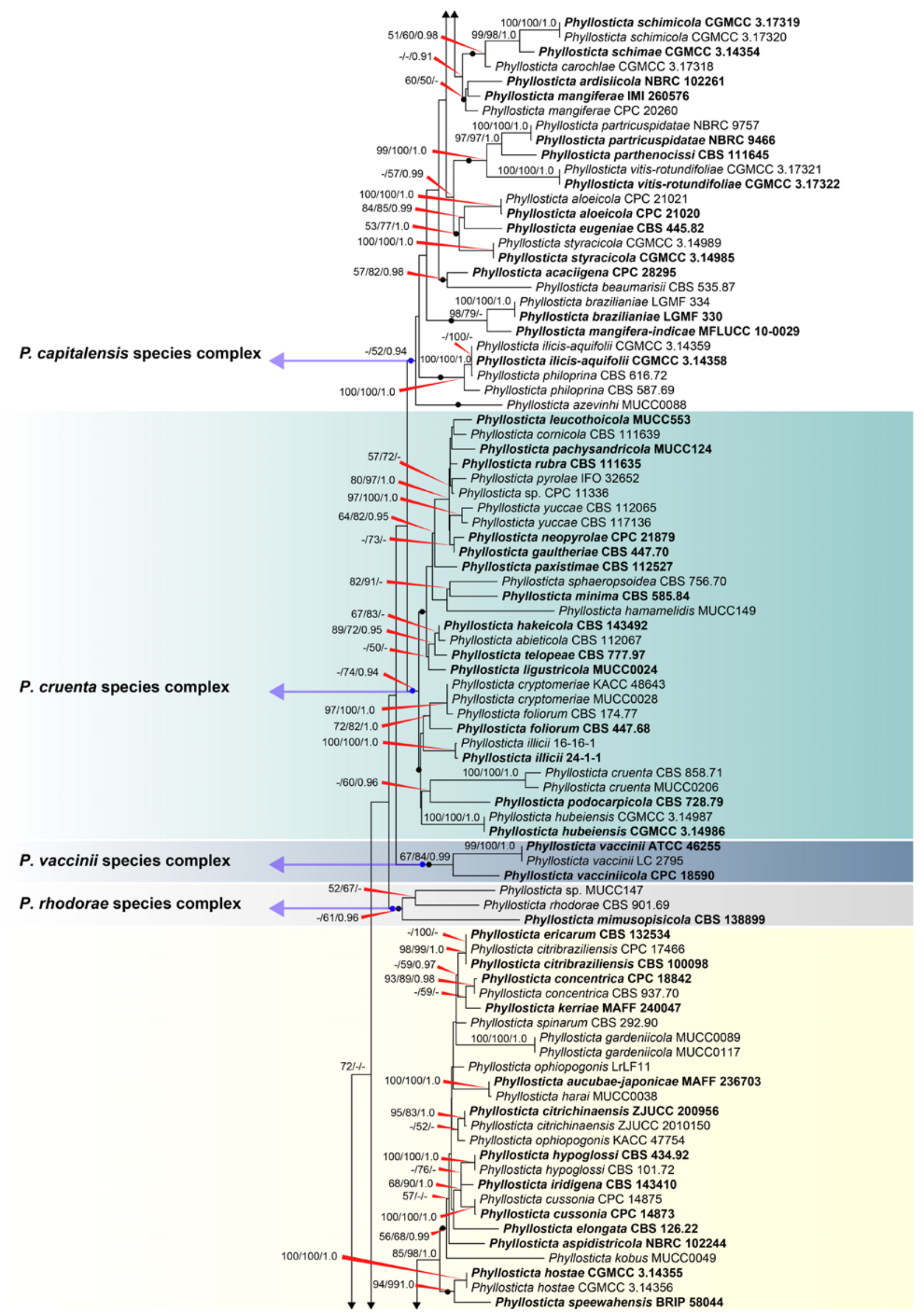

Figure 1 - Continued. 


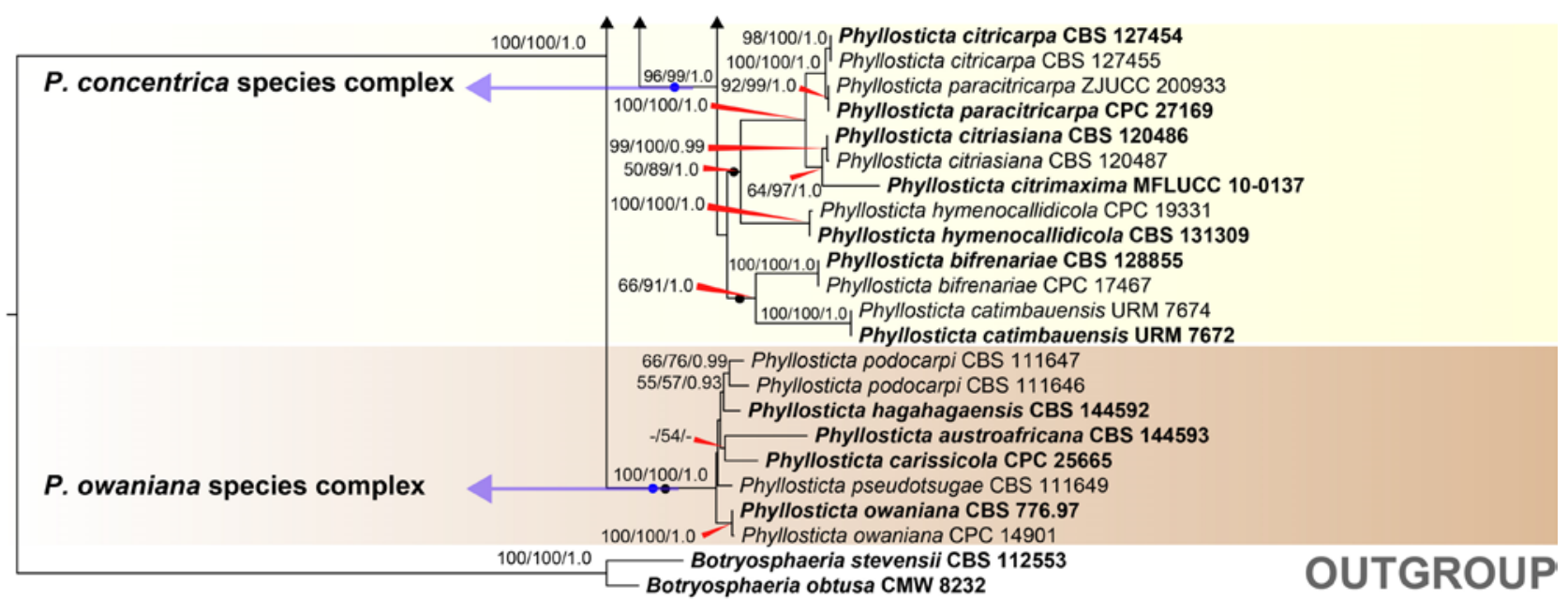

0.06

Figure 1 - Continued.

Notes - 25 species are included in the $P$. concentrica species complex. Members of this species complex have mostly been reported as pathogenic and endophytic fungi from a wide range of hosts (Supplementary Table 1). Phyllosticta citricarpa, an important pathogenic fungus causing leaf spot and citrus black spot disease on Citrus, Poncirus, Fortunella and their hybrids are included in this clade (van der Aa 1973, Guarnaccia et al. 2017, Boughalleb-M'Hamdi et al. 2020). Phyllosticta concentrica is used to describe this species complex based on publication year. Species of this complex are characterized by conidia that are globose or ellipsoid to obvoid enclosed in a thin persistent sheath with apical mucoid appendage; ascospore are fusiform to ellipsoid, wider at the mid region, both ends rounded with gelatinous caps (Supplementary Table 2). The sexual morph of $P$. citrichinensis has been reported in this group. The clade for this species complex is robust and recovered in all analyses (Fig. 1, Supplementary Figs 1-5).

Phyllosticta concentrica was introduced by Saccardo for fungi on leaves of Hedera helix in Italy (Wikee et al. 2013b). Later, the species was introduced from withering, leaf litter, and living leaves in a wide range of hosts (Supplementary Table 1).

\section{Phyllosticta cruenta species complex}

Species included in the Phyllosticta cruenta species complex - P. abieticola, P. cornicola, P. cruenta, $P$. cryptomeriae, $P$. foliorum, $P$. gaultheriae, $P$. hakeicola, $P$. hamamelidis, $P$. hubeiensis, P. illicii, P. leucothoicola, P. ligustricola, P. minima, P. neopyrolae, P. pachysandricola, $P$. paxistimae, $P$. podocarpicola, $P$. paviae, $P$. pyrolae, $P$. rubella, $P$. telopeae.

Notes - This species complex consists of 21 species, which have mostly been reported as pathogenic and endophytic from a wide range of hosts (Supplementary Table 1). Phyllosticta cruenta is used to describe this species complex name based on the publication year. Species of this complex are characterized by conidia that are globose or elongate, ellipsoid to obovoid with mucoid sheath or some species with mucous sheath ( $P$. pachysandricola) with or without apical mucoid appendage; ascospores limoniform with obtuse ends, rarely curved (Supplementary Table 2). Sexual morphs of two species have been reported in this group (P. abieticola, P. rubella). This clade was not resolved based on single-locus trees of LSU, efl $\alpha$, and gapdh, while ITS and actin topologies provided better resolution for this species complex as combined gene tree (Fig. 1, Supplementary Figs 1-5).

\section{Phyllosticta owaniana species complex}

Species included in the Phyllosticta owaniana species complex - P. austroafricana, $P$. carissicola, $P$. hagahagaensis, $P$. owaniana, $P$. podocarpi, $P$. pseudotsugae. 


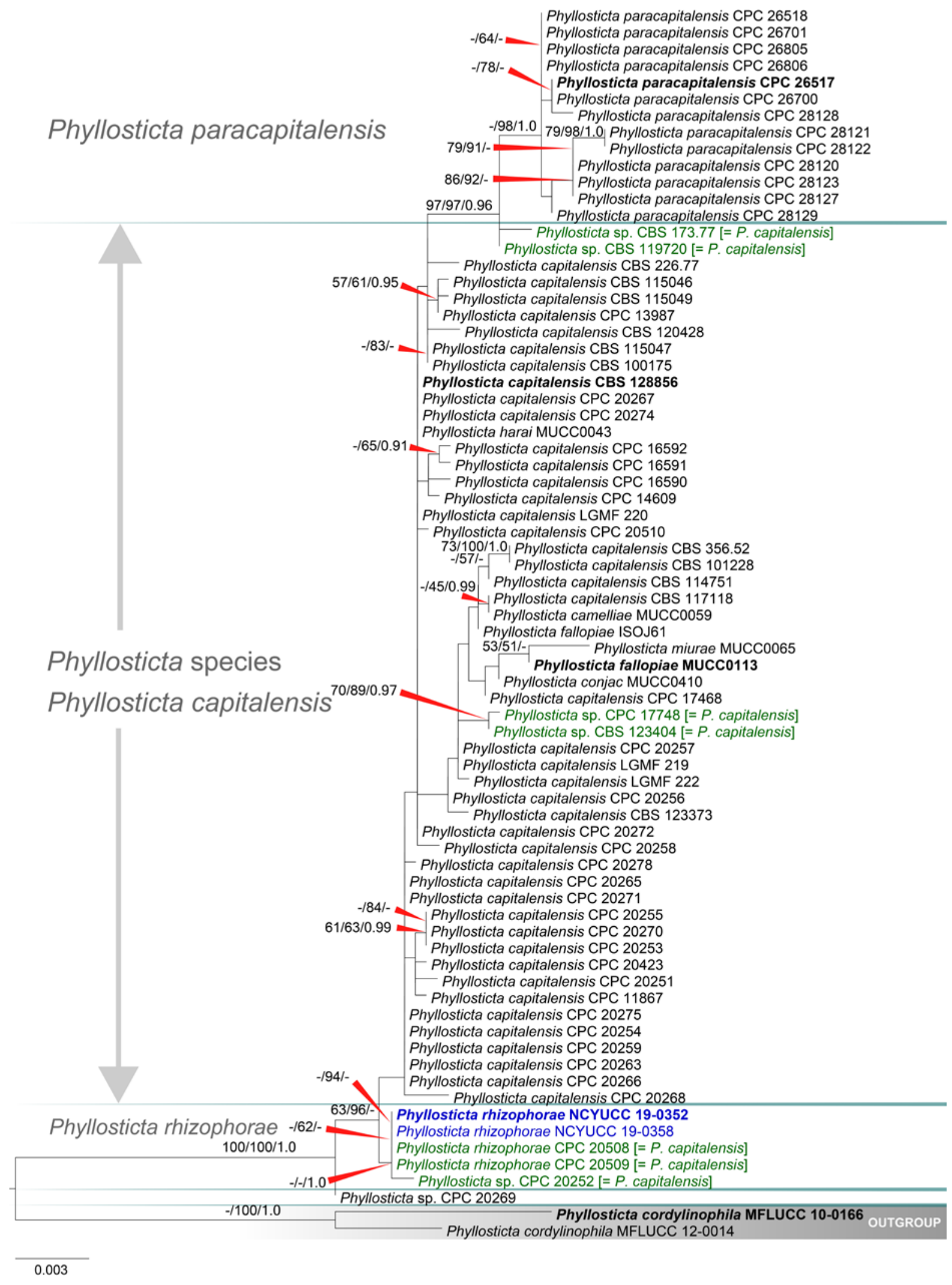

Figure 2 - Phylogenetic tree generated from maximum likelihood analysis based on combined ITS, LSU, efl $\alpha$, actin and gapdh sequence data from 74 strains of Phyllosticta. The tree is rooted to $P$. cordylinophila strain MFLUCC 10-0166 and MFLUCC 12-0014. Maximum parsimony and maximum likelihood bootstrap values $\leq 50 \%$, and Bayesian posterior probabilities $\leq 0.90$ are given at the nodes in this order. The species obtained in this study are in blue and species synonymized are in green. Ex-type taxa from other studies are in bold. 
Notes - Six species are included in the P. owaniana species complex. Members of this species complex are mostly reported as pathogenic causing leaf spots on Carissa spp., Brabejum sp., Podocarpus spp., and endophytic fungi on Cryptomeria sp., and Pseudotsuga spp. (Supplementary Table 1). Phyllosticta owaniana is used to describe this species complex based on the publication year. Species of this complex are characterized by conidia that are ellipsoid to obovoid, tapering towards a narrow truncate base, coarsely guttulate, or with a single large central guttule, enclosed in a thin persistent mucoid sheath and with or without apical mucoid appendage; ascospores are fusiform to ellipsoid, with hyaline gelatinous caps at both ends (Supplementary Table 2). The sexual morph of $P$. podocarpi has been reported in this group. The complex is recovered in the multilocus and single locus (except for LSU) trees (Supplementary Figs 1-5).

Winter (1885) introduced Phyllosticta owaniana, which is a pathogenic fungus causing serious leaf spot disease on Brabejum stellatifolium in South Africa. The species was mentioned as being a specific species for this host (Doidge 1950, Swart et al. 1998, Crous et al. 2000, Wulandari et al. 2009, Sultan et al. 2011, Glienke et al. 2011, Wikee et al. 2011, 2013a, b, Miles et al. 2013, Zhou et al. 2015, Hyde et al. 2014).

\section{Phyllosticta rhodorae species complex} rhodorae.

Species included in the Phyllosticta rhodorae species complex - P. mimusopisicola, P.

Notes - Two species were included in the P. rhodorae species complex. Crous et al. (2014) introduced Phyllosticta mimusopisicola, a pathogen causing leaf spot disease on Mimusops zeyheri in Aflica. Phyllosticta rhodorae is found on Rhododendron spp., which was recombined by Tassi (1902) (三 Phoma rhodorae Cooke). Phyllosticta rhodorae is used to describe this species complex based on publication year. Species of this complex are characterized by conidia that are ellipsoid to obovoid, tapering towards a narrow truncate base, coarsely guttulate, or with a single large central guttule, persistent mucoid sheath and apical mucoid appendage (Supplementary Table 2). The sexual morph has not been reported for this species complex. The complex is recovered in the mulitlocus and LSU trees.

\section{Phyllosticta vaccinii species complex}

Species included in the Phyllosticta vaccinii species complex $-P$. vaccinii, $P$. vacciniicola.

Notes - Two species are included in the $P$. vaccinii species complex. Members of this species complex have mostly been reported as pathogenic and endophytic on Vaccinium spp. (Supplementary Table 1). Phyllosticta vaccinii is used to describe this species complex based on publication year. Earle (1897) introduced P. vaccinii from leaf spot of Vaccinium arboretum in Alabama. This species has been isolated from a wide range of Vaccinium (Hyde et al. 2014, Zhou et al. 2015). Detailed host information and distribution is provided in Supplementary table 1. This species complex is characterized by conidia that are ellipsoid to obovoid, obpyriform, tapering towards a narrow truncate base, enclosed in a thin persistent mucoid sheath with a mucoid appendage (Supplementary Table 2). The sexual morph has not been reported for this species complex. The complex is robust and recovered in the multi- and single locus trees (Fig. 1, Supplementary Figs 1-5).

Phyllosticta rhizophorae Norph. \& Hyde K.D. sp. nov.

Fig. 3

Index Fungorum number: IF557808, Facesoffungi number: FoF08021

Etymology - refers to the host, Rhizophora stylosa, of the type strain.

Holotype - NCYUCC 19-0352

Associated with leaf spots of Rhizophora stylosa. Symptoms irregular to subcircular shape, brown, slightly sunken spots appear on adaxial surface leaves of $R$. stylosa, which later expand outwards on the surface of the leaves (Fig. 3b). Small auburn spots appeared initially and then gradually enlarged, changing to tawny circular ring spots with a dark mahogany border and jagged edge. They were usually $>5$ circulars, which occurred on a single affected leaf. In severe cases, 
lesions spread evenly on the leaves (Fig. 3c). Sexual morph: Ascomata similar to conidiomata in general anatomy, long neck. Asci 33-55 $\times 4-6.5 \mu \mathrm{m}$, bitunicate, clavate to broadly fusoid-ellipsoid, with visible apical chamber, 1-2 $\mu \mathrm{m}$ diam. Ascospores (12.5-)14-19(-21.5) $\times 4.1-7.7 \mu \mathrm{m},(\mathrm{mean} \pm$ $\mathrm{SD}=16 \pm 2.9 \times 6.1 \pm 1.2 \mu \mathrm{m})$, bi-seriate, hyaline, smooth, aseptate, granular to guttulate, straight and slightly curved, widest in the middle, limoniform with obtuse ends, with distinct hyaline gelatinous caps at both ends, 3.5-5.5 × 1.5-3 $\mu \mathrm{m}$. Asexual morph: Conidiomata pycnidial up to 700 $\mu \mathrm{m}$ diam., solitary, black, erumpent, globose including colorless to opaque conidial masses. Conidiomata pycnidial up to $200 \mu \mathrm{m}$ diam., solitary, black, erumpent, globose to pyriform, including colorless to opaque conidial masses in PA. Pycnidial wall of several layers, composed of cells of textura angularis, thick, inner wall of hyaline textura angularis cells. Central ostiole, up to $10 \mu \mathrm{m}$ diam. Conidiophores reduced to conidiogenous cells, 13-25 $\times 3-5 \mu \mathrm{m}$, subcylindrical to ampulliform, or with 1-2 supporting cell, that can be branched at the base. Conidiogenous cells 10$17 \times 3-5 \mu \mathrm{m}$, terminal, subcylindrical, hyaline, smooth, proliferating several times percurrently near apex. Conidia $(13-) 15-17(-19.5) \times 6-7(-8) \mu \mathrm{m},($ mean $\pm \mathrm{SD}=16.7 \pm 0.5 \times 7.3 \pm 1.6 \mu \mathrm{m})$, solitary, hyaline, aseptate, thin and smooth walled, coarsely guttulate, or with a single large central guttulate, broadly ellipsoid or ellipsoid to obovoid, tapering towards a narrow truncate base, enclosed in a persistent mucoid sheath, 1-8 $\mu \mathrm{m}$ thick, and bearing a hyaline, apical mucoid appendage, (5-)9-11(-16) × 6-8(-12) $\mu \mathrm{m}$, flexible, unbranched, tapering towards an acutely rounded tip, rarely with a short apical appendage. Spermatia hyaline, smooth, guttulate to granular, bacilliform, 7.5-11.5 × 1-2 $\mu \mathrm{m}$, occurring in conidioma with conidia.

Material examined - TAIWAN, Tainan, Shicao, on leaf spot of Rhizophora stylosa, July 15, 2018, Chada Norphanphoun SC0 (NCYUCC 19-0352 dried culture, holotype; MFLU, isotype), extype living culture NCYUCC 19-0352, NCYUCC 19-0358, MFLUCC.

Distribution - Cordyline fruticosa (Thailand), Heliconia sp. (Thailand), Ixora chinensis (Thailand), Musa paradisiaca (Thailand), Punica granatum (Thailand), Rhizophora stylosa (Taiwan).

Notes - Phyllosticta rhizophorae is closely related to $P$. capitalensis based on DNA sequence data in BLAST searches and phylogenetic analysis (Fig. 1). However, phylogenetic analyses of selected strains in Fig. 2 indicate that the new taxon groups with five published strains of $P$. capitalensis (CPC 20508, CPC20509, CPC 20252, CBS 123404 and CPC 17748) as a distinct clade, and is separate from $P$. capitalensis species group, which contains the ex-type strain (Fig. 2). The morphology of $P$. rhizophorae is different from that of $P$. capitalensis (Table 4). Hence, $P$. rhizophorae is established based on morphological and molecular data. Two strains of $P$. capitalensis (CPC 20508, CPC20509) are synonymized under P. rhizophorae based on phylogenetic analyses (Fig. 2). The new collection is designated as the type material. Strains CPC 20252, CBS 123404 and CPC 17748 are treated as unnamed species as they form a separate clade from our new collection in both phylogenetic trees (Figs 1, 2).

Pathogenicity testing - The ability of Phyllosticta rhizophorae strains isolated from leaf spots of Rhizophora stylosa in Taiwan to induce leaf spot symptoms on Rhizophora stylosa was tested through inoculating a spore suspension and mycelial plugs onto wounded and unwounded living leaves. In all cases there was no symptoms on the young healthy plant leaves.

\section{Discussion}

The taxonomy of Phyllosticta is challenging. Phyllosticta species have overlapping morphological traits, making it difficult to pinpoint taxonomically relevant characters. Reliance on host association for traditional identification of Phyllosticta species has further complicated matters. Collectivelly, these issues have led to taxonomic confusion. Molecular phylogenetic tools have greatly facilitated identification of species and establishment of species complexes (Baayen et al. 2002, Okane et al. 2003, Motohashi et al. 2009, Wikee et al. 2012, Wulandari et al. 2009, Glienke et al. 2011). In this study, both combined and single locus data were considered. 


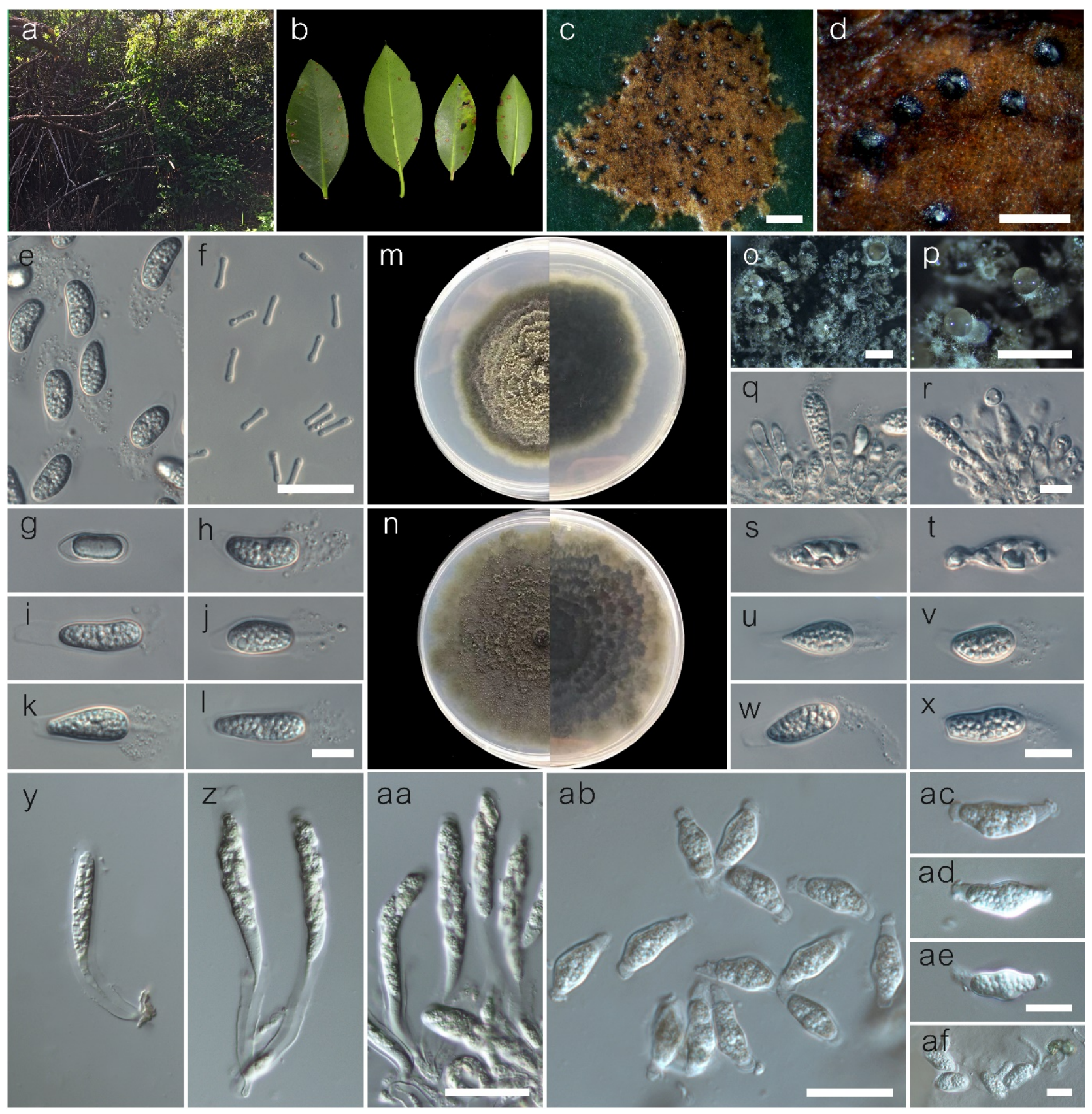

Figure 3 - Phyllosticta rhizophorae (NCYUCC19-0352). a Habitat. b Leaf spots on Rhizophora stylosa. c-d Surface of leaf spot with fruiting bodies. e, g-l, s-x Conidia. f Spermatia. $\mathrm{m}$, o-p Colony of asexual morph on PDA. n Colony of sexual morph on PA (left-above, rightreverse). q-r Conidiophore with Conidia developing on conidiogenous cells. $\mathrm{y}-\mathrm{aa}$ Asci. ab-ae Ascospores. af Ascospores germinating on WA. (a-l morphology from leaf spot, m-af morphology from culture). Scale bars: $\mathrm{c}, \mathrm{o}-\mathrm{p}=1 \mathrm{~mm}, \mathrm{~d}=500 \mu \mathrm{m}, \mathrm{e}-\mathrm{f}, \mathrm{g}-\mathrm{l}, \mathrm{q}-\mathrm{r}, \mathrm{s}-\mathrm{x}, \mathrm{ac}-\mathrm{af}=$ $10 \mu \mathrm{m}, \mathrm{y}-\mathrm{aa}=15 \mu \mathrm{m}, \mathrm{ab}=20 \mu \mathrm{m}$.

Multilocus trees provided better resolution of Phyllosticta species than single-locus trees (Supplementary Figs 1-5). Adding protein-coding genes to the analysis greatly facilitated species level identification. Based on the results of our phylogenetic analyses we have introduced six species complexes in Phyllosticta: P. capitalensis, P. concentrica, P. cruenta, P. owaniana, P. rhodorae, and $P$. vaccinii. Splitting of Phyllosticta into clades will allow for easier resolution of species. Eighty-four previously described species including a new species were assigned to one of the six species complexes. Given that species delineation in Phyllosticta is difficult due to the above-mentioned challenges, the complexes can be used as broader descriptors of the genus. 
Following the same reasoning and for the sake of communication, species complexes have been introduced successfully for Colletotrichum (Cannon et al. 2012, Damm et al. 2019, Jayawardena et al. 2016, da Silva et al. 2020), and Fusarium (O’Donnell et al. 2013, 2015, Al-Hatmi et al. 2016).

Multilocus phylogeny and at least two single locus analyses support the six individual Phyllosticta species complexes, some of which have strong statistical support (Fig. 1). Nonetheless, placement of some species remains problematic and additional loci are needed for taxonomic resolution. Results from this study demonstrate that both molecular phylogenetic analyses and morphological data are needed to propose and establish species of Phyllosticta, as the latter alone is not sufficient. The molecular boundaries of species of Phyllosticta will provide a better understanding of inter and intraspecific variation within the genus, particularly within the broader species complexes.

Demarcation of individual taxa within the genus is essential so that we develop a better understanding of the lifestyles, ecology, and overall biology of these individual taxa and their impact and control in various ecosystems. Hence, in this study six strains of $P$. capitalensis are unnamed species (strains CBS 173.77, CBS 119720, CPC 17748, CPC 20252, CPC 20269, and CBS 123404) based on nucleotide polymorphisms and phylogenetic analyses. Seventeen strains were excluded from Phyllosticta. Seventeen strains - Phyllosticta alcides strain P3-4 (PalomaresRius et al. 2014), P. artocarpina strain B5 (Baayen et al. 2002), P. caprifolii strain F23 (unpublished), P. citrullina strain LrBF12 (unpublished), P. citrullina strain LrBF13 (unpublished), P. coryli strain CTF324 (Sun et al. 2013), P. flevolandica strain AFTOL-ID 1786 (unpublished), $P$. flevolandica strain CBS 998.72 (Vu et al. 2019), P. heveae strain NW197 (unpublished), P. jasmini strain TS08-19-2 (unpublished), P. jasmini strain 6259 (unpublished), P. juglandis strain H2 (unpublished), $P$. ligustri strain TS08-20-1 (unpublished), $P$. papayae strain T150 (unpublished), $P$. papayae strain 7AJ-10 (unpublished), $P$. populina strain NW584 (unpublished), and $P$. sojicola strain CBS 301.39 (Vu et al. 2019) - were excluded from Phyllosticta based on BLAST searches against type material (Table 6). The BLAST results for the above 17 strains denoted as Phyllosticta matched other genera to the exclusion of Phyllosticta. In the phylogenetic tree, these 17 strains were excluded from the Phyllosticta clade (data not shown). Sixteen of these strains were submitted to the database based on sequence data alone without accompanying morphological support. One strain, $P$. coryli CTF324, was published with only the ITS gene region and morphological characters of unicellular conidia, colorless, ovoid to oval, and from 2.4-4.5 × 1.6-2.4 $\mu \mathrm{m}$ (Sun et al. 2013). The morphology of $P$. coryli strain CTF324 corresponds more closely to species of Didymella and Peyronellaea in Didymellaceae, an observation that is also supported by the BLAST search results (Table 6). Finally, a new species, Phyllosticta rhizophorae, is introduced in this study. Two strains of P. capitalensis (CPC 20508, and CPC 20509) were synonymized under the new species.

Description of the new species is based on both morphological and molecular data. The new species was found on mangrove plants in Taiwan (leaf spot of Rhizophora stylosa) and isolated using tissue isolation. During the research period, a new species and new strains of previously known species from mangroves in Taiwan were reported. For example, Pestalotiopsis kandelicola, P. kenyana, P. diploclisiae were isolated from asymptomatic leaves of Kandelia candel (Hyde et al. 2020a, b), while Alternaria sp. was associated with leaf blight of Ficus sp. and leaf spot of Kandelia candel (Norphanphoun et al. in prep). Collectively, these results suggest that there might be a large number of undescribed species, both endophytes and pathogens, in this ecosystem. Pathogenicity testing of $P$. rhizophorae was negative. Phyllosticta species have only rarely been isolated from leaf spots and black spots of fruits, but they have also been found as endophytes of diverse host plants, and as saprobes (Okane et al. 2003, Glienke et al. 2011, Guarnaccia et al. 2017, Tran et al. 2019, Wikee et al. 2011, 2013b). Taken together, it seems that Phyllosticta species are widely distributed and appear to have different lifestyles, which ranges from pathogens, latent pathogens, and endophytes. Further studies are needed to establish whether these species are hostspecific, their habitats and lifestyle, as well as the conditions under which they might switch. 
Table 4 Morphological characteristics comparison of Phyllosticta species related to this study.

\begin{tabular}{|c|c|c|c|c|c|c|c|c|c|c|c|c|c|c|c|c|}
\hline \multirow[t]{2}{*}{ Species } & \multirow[t]{2}{*}{ Strain } & \multicolumn{2}{|c|}{ Ascomata } & \multicolumn{2}{|c|}{ Asci } & \multicolumn{2}{|c|}{ Ascospores } & \multicolumn{2}{|c|}{ Conidiomata } & \multicolumn{2}{|c|}{$\begin{array}{c}\text { Conidiogenous } \\
\text { cells }\end{array}$} & \multicolumn{2}{|c|}{ Conidia } & \multicolumn{2}{|c|}{ Spermatia } & \multirow[t]{2}{*}{$\begin{array}{c}\text { Referenc } \\
\text { e }\end{array}$} \\
\hline & & Size* & Shape & Size* & Shape & Size* & Shape & Size* & Shape & Size* & Shape & Size* & Shape & Size* & Shape & \\
\hline P. capitalensis & $\begin{array}{l}\text { CBS } \\
128856^{\mathrm{T}}\end{array}$ & 250 & $\begin{array}{l}\text { globose } \\
\text { to } \\
\text { pyriform }\end{array}$ & $\begin{array}{l}58-80 \\
\times 11- \\
15\end{array}$ & clavate & $\begin{array}{l}15-17 \\
\times 5-6\end{array}$ & $\begin{array}{l}\text { limoni } \\
\text { form }\end{array}$ & $\begin{array}{l}300 \times \\
250\end{array}$ & $\begin{array}{l}\text { globose } \\
\text { to } \\
\text { ampullif } \\
\text { orm }\end{array}$ & $\begin{array}{l}7-10 \times \\
3-5\end{array}$ & $\begin{array}{l}\text { subcylin } \\
\text { drical to } \\
\text { ampullif } \\
\text { orm to } \\
\text { doliiform }\end{array}$ & $\begin{array}{l}(10-) 11- \\
12(-14) \\
\times(5-) 6- \\
7\end{array}$ & $\begin{array}{l}\text { ellipsoid } \\
\text { to } \\
\text { obovoid }\end{array}$ & N/A & N/A & $\begin{array}{l}\text { Hennings } \\
\text { (1908) }\end{array}$ \\
\hline P. fallopiae & $\begin{array}{l}\text { MUCC01 } \\
\text { 13/ NBRC } \\
102266^{\mathrm{T}}\end{array}$ & N/A & N/A & N/A & N/A & N/A & N/A & $\begin{array}{r}63.5-98 \\
\times 61-98\end{array}$ & $\begin{array}{l}\text { sub } \\
\text { globose } \\
\text { to } \\
\text { globose }\end{array}$ & $\begin{array}{l}5-10 \times \\
1.2-2.5\end{array}$ & $\begin{array}{l}\text { cylindric } \\
\text { al to } \\
\text { subcylin } \\
\text { drical }\end{array}$ & $\begin{array}{l}8.5-12.5 \\
\times 6-7.5\end{array}$ & $\begin{array}{l}\text { ellipsoid } \\
\text { to } \\
\text { obovoid }\end{array}$ & N/A & N/A & $\begin{array}{l}\text { Motohashi } \\
\text { et al. } \\
\text { (2008) }\end{array}$ \\
\hline P. paracapitalensis & $\begin{array}{l}\text { CPC } \\
26517^{\mathrm{T}}\end{array}$ & $>300$ & globose & $\begin{array}{l}40-75 \\
\times 10- \\
12\end{array}$ & $\begin{array}{l}\text { subcylin } \\
\text { drical to } \\
\text { clavate }\end{array}$ & $\begin{array}{l}16-17 \\
\times 6(-7)\end{array}$ & $\begin{array}{l}\text { limoni } \\
\text { form }\end{array}$ & $>250$ & globose & $\begin{array}{l}7-15 \times \\
3-4\end{array}$ & $\begin{array}{l}\text { subcylin } \\
\text { drical }\end{array}$ & $\begin{array}{l}(9-) 12- \\
13(-14) \\
\times(6-) 7\end{array}$ & $\begin{array}{l}\text { ellipsoid } \\
\text { to } \\
\text { obovoid }\end{array}$ & N/A & N/A & $\begin{array}{l}\text { Guarnaccia } \\
\text { et al. } \\
\text { (2017) }\end{array}$ \\
\hline P. rhizophorae & $\begin{array}{l}\text { NCYUCC } \\
\text { 19-0358/ } \\
19-0352\end{array}$ & $>200$ & $\begin{array}{l}\text { globose } \\
\text { to } \\
\text { pyriform }\end{array}$ & $\begin{array}{l}33-55 \\
\times 4- \\
6.5\end{array}$ & $\begin{array}{l}\text { clavate } \\
\text { to } \\
\text { broadly } \\
\text { fusoid- } \\
\text { ellipsoid }\end{array}$ & $\begin{array}{l}16 \pm 2.9 \\
\times 6.1 \pm \\
1.2\end{array}$ & $\begin{array}{l}\text { limoni } \\
\text { form } \\
\text { with } \\
\text { obtuse } \\
\text { ends }\end{array}$ & $>200$ & globose & $\begin{array}{l}10-17 \\
\times 3-5\end{array}$ & $\begin{array}{l}\text { subcylin } \\
\text { drical }\end{array}$ & $\begin{array}{l}16.7 \pm \\
0.5 \times 7.3 \\
\pm 1.6\end{array}$ & $\begin{array}{l}\text { ellipsoid } \\
\text { to } \\
\text { obovoid }\end{array}$ & $\begin{array}{l}7.5- \\
11.5 \\
\times 1- \\
2\end{array}$ & $\begin{array}{l}\text { bacilli } \\
\text { form }\end{array}$ & $\begin{array}{l}\text { In this } \\
\text { study }\end{array}$ \\
\hline
\end{tabular}

*Size was mentioned in $\mu \mathrm{m} ;{ }^{\mathrm{T}}$ Type species; N/A no morphology mentioned in publication.

Table 5 GenBank BLAST search results of Phyllosticta strains that clustered with P. capitalensis in this study.

\begin{tabular}{|c|c|c|c|c|c|c|c|c|}
\hline \multirow[b]{2}{*}{ Taxon } & \multirow[b]{2}{*}{ Strain** } & \multirow[b]{2}{*}{ Host } & \multirow[b]{2}{*}{ Country } & \multirow[b]{2}{*}{$\begin{array}{l}\text { GenBank } \\
\text { accession no.* }\end{array}$} & \multicolumn{4}{|c|}{ GenBank BLAST search results } \\
\hline & & & & & Species identified & Strain** & $\begin{array}{l}\text { Accession } \\
\text { no. }\end{array}$ & $\begin{array}{l}\text { Identities (I), } \\
\text { Query cover (QC) }\end{array}$ \\
\hline \multirow[t]{10}{*}{ P. harai } & MUCC0043 $^{b}$ & Aucuba japonica & Japan & $\mathrm{AB} 454281 \mathbf{\Delta}$ & Phyllosticta fallopiae & MUCC0113 b & AB454307 & $100.00 \%(\mathrm{I}), 100 \%$ (QC) \\
\hline & & & & & Guignardia philoprina & MUCC0027 b & AB454270 & $100.00 \%$ (I), $100 \%$ (QC) \\
\hline & & & & & Phyllosticta elongata & CBS $114751^{\mathrm{d}}$ & EU167584 & $100.00 \%$ (I), $100 \%$ (QC) \\
\hline & & & & & Phyllosticta sp. & MUCC0547 b & AB454364 & $99.92 \%(\mathrm{I}), 100 \%$ (QC) \\
\hline & & & & & Guignardia mangiferae & MUCC0207 b & AB454332 & $99.92 \%(\mathrm{I}), 100 \%(\mathrm{QC})$ \\
\hline & & & & AB704219• & Phyllosticta sphaeropsoidea & MUCC0112 a & AB704227 & $100.00 \%$ (I), $100 \%$ (QC) \\
\hline & & & & & Guignardia sawadae & MUCC0066 a & AB704225 & $100.00 \%$ (I), $100 \%$ (QC) \\
\hline & & & & & Guignardia mangiferae & MUCC0030 a & AB704215 & $100.00 \%$ (I), 99\% (QC) \\
\hline & & & & & Guignardia mangiferae & MUCC0122 a & AB704231 & $99.6 \%(\mathrm{I}), 100 \%(\mathrm{QC})$ \\
\hline & & & & & Phyllosticta conjac & MUCC0410 a & AB704239 & $99.6 \%(\mathrm{I}), 100 \%$ (QC) \\
\hline
\end{tabular}


Table 5 Continued.

\begin{tabular}{|c|c|c|c|c|c|c|c|c|}
\hline \multirow[b]{2}{*}{ Taxon } & \multirow[b]{2}{*}{ Strain** } & \multirow[b]{2}{*}{ Host } & \multirow[b]{2}{*}{ Country } & \multirow{2}{*}{$\begin{array}{l}\text { GenBank } \\
\text { accession no.* }\end{array}$} & \multicolumn{4}{|c|}{ GenBank BLAST search results } \\
\hline & & & & & Species identified & Strain** & $\begin{array}{l}\text { Accession } \\
\text { no. }\end{array}$ & $\begin{array}{l}\text { Identities (I), } \\
\text { Query cover (QC) }\end{array}$ \\
\hline \multirow[t]{10}{*}{ P. fallopiae } & MUCC0113 $^{b}$ & Fallopia & Japan & AB454307 A & Phyllosticta elongata & CBS $114751^{d}$ & EU167584 & $100.00 \%$ (I), $100 \%$ (QC) \\
\hline & & japonica & & & Guignardia philoprina & MUCC0027 b & AB454270 & $100.00 \%$ (I), 99\% (QC) \\
\hline & & & & & Phyllosticta sp. & MUCC0547 b & AB454364 & $99.92 \%(\mathrm{I}), 99 \%$ (QC) \\
\hline & & & & & Guignardia mangiferae & MUCC0207 b & AB454332 & $99.92 \%(\mathrm{I}), 99 \%$ (QC) \\
\hline & & & & & Guignardia sp. & MUCC0041 b & AB454279 & $99.92 \%(\mathrm{I}), 100 \%(\mathrm{QC})$ \\
\hline & & & & AB704228• & Phyllosticta miurae & MUCC0065 a & AB704224 & $100.00 \%(\mathrm{I}), 100 \%$ (QC) \\
\hline & & & & & Phyllosticta sphaeropsoidea & MUCC0112 a & AB704227 & $100.00 \%$ (I), 99\% (QC) \\
\hline & & & & & Guignardia philoprina & MUCC0012 a & AB704206 & $99.6 \%(\mathrm{I}), 100 \%$ (QC) \\
\hline & & & & & Phyllosticta conjac & MUCC0410 a & AB704239 & $99.6 \%(\mathrm{I}), 100 \%$ (QC) \\
\hline & & & & & Guignardia mangiferae & MUCC0122 a & AB704231 & $99.6 \%(\mathrm{I}), 99 \%(\mathrm{QC})$ \\
\hline \multirow[t]{10}{*}{ P. conjac } & MUCC0410 b & Amorphophallus & Japan & $\mathrm{AB} 454342 \boldsymbol{\Delta}$ & Phyllosticta fallopiae & MUCC0113 b & AB454307 & $100.00 \%(\mathrm{I}), 100 \%$ (QC) \\
\hline & & rivieri & & & Guignardia philoprina & MUCC0027 b & AB454270 & $100.00 \%$ (I), $100 \%$ (QC) \\
\hline & & & & & Phyllosticta elongata & CBS $114751^{b}$ & EU167584 & $100.00 \%$ (I), $100 \%$ (QC) \\
\hline & & & & & Phyllosticta sp. & MUCC0547 b & AB454364 & $99.92 \%(\mathrm{I}), 100 \%$ (QC) \\
\hline & & & & & Guignardia mangiferae & MUCC0207 b & AB454332 & $99.92 \%(\mathrm{I}), 100 \%$ (QC) \\
\hline & & & & AB704239• & Guignardia philoprina & MUCC0012 a & AB704206 & $100.00 \%(\mathrm{I}), 100 \%$ (QC) \\
\hline & & & & & Phyllosticta fallopiae & MUCC0113 $^{\mathrm{a}}$ & AB704228 & $99.6 \%(\mathrm{I}), 100 \%(\mathrm{QC})$ \\
\hline & & & & & Phyllosticta sphaeropsoidea & MUCC0112 a & AB704227 & $99.6 \%(\mathrm{I}), 100 \%$ (QC) \\
\hline & & & & & Guignardia sawadae & MUCC0066 $^{\text {a }}$ & AB704225 & $99.6 \%$ (I), $100 \%$ (QC) \\
\hline & & & & & Phyllosticta miurae & MUCC0065 a & AB704224 & $99.6 \%(\mathrm{I}), 100 \%$ (QC) \\
\hline \multirow[t]{5}{*}{ P. fallopiae } & ISOJ61 ${ }^{\mathrm{c}}$ & & & MF164545 $\Delta$ & Phyllosticta capitalensis & A788 u & MN121397 & $100.00 \%$ (I), $100 \%$ (QC) \\
\hline & & & & & Phyllosticta elongata & LCM $886.01^{\text {u }}$ & MF495420 & $100.00 \%$ (I), $100 \%$ (QC) \\
\hline & & & & & Phyllosticta capitalensis & LCM $826.01^{\text {u }}$ & MF495391 & $100.00 \%$ (I), $00 \%$ (QC) \\
\hline & & & & & Phyllosticta capitalensis & LCM $818.01^{u}$ & MF495383 & $100.00 \%$ (I), $100 \%$ (QC) \\
\hline & & & & & Phyllosticta capitalensis & VPRI41231 u & MH183391 & $100.00 \%$ (I), $100 \%$ (QC) \\
\hline \multirow[t]{10}{*}{ P. miurae } & MUCC0065 b & Lindera praecox & Japan & $\mathrm{AB} 454291 \boldsymbol{\Delta}$ & Guignardia alliacea & $\operatorname{MUCC0015}^{\mathrm{a}}$ & AB454264 & $100.00 \%$ (I), $100 \%$ (QC) \\
\hline & & & & & Guignardia alliacea & MUCC0014 $^{\text {a }}$ & AB454263 & $99.92 \%(\mathrm{I}), 100 \%$ (QC) \\
\hline & & & & & Guignardia philoprina & MUCC0012 a & AB454262 & $99.83 \%$ (I), 100\% (QC) \\
\hline & & & & & Guignardia mangiferae & MUCC0122 a & AB454315 & 99.83\% (I), 100\% (QC) \\
\hline & & & & & Phyllosticta fallopiae & $\operatorname{MUCC} 113^{\mathrm{a}}$ & AB454307 & $99.75 \%$ (I), 100\% (QC) \\
\hline & & & & AB704224• & Phyllosticta fallopiae & MUCC0113 $^{\mathrm{a}}$ & AB704228 & $100 \%(\mathrm{I}), 100 \%(\mathrm{QC})$ \\
\hline & & & & & Phyllosticta conjac & MUCC0410 a & AB704239 & $99.6 \%$ (I), 100\% (QC) \\
\hline & & & & & Guignardia mangiferae & MUCC0122 a & AB704231 & $99.6 \%(\mathrm{I}), 100 \%$ (QC) \\
\hline & & & & & Phyllosticta sphaeropsoidea & MUCC0112 a & AB704227 & $99.6 \%$ (I), $100 \%$ (QC) \\
\hline & & & & & Guignardia sawadae & MUCC0066 $^{\text {a }}$ & AB704225 & $99.6 \%(\mathrm{I}), 100 \%$ (QC) \\
\hline
\end{tabular}


Table 5 Continued.

\begin{tabular}{|c|c|c|c|c|c|c|c|c|}
\hline \multirow[b]{2}{*}{ Taxon } & \multirow[b]{2}{*}{ Strain** } & \multirow[b]{2}{*}{ Host } & \multirow[b]{2}{*}{ Country } & \multirow[b]{2}{*}{$\begin{array}{l}\text { GenBank } \\
\text { accession no.* }\end{array}$} & \multicolumn{4}{|c|}{ GenBank BLAST search results } \\
\hline & & & & & Species identified & Strain** & $\begin{array}{l}\text { Accession } \\
\text { no. }\end{array}$ & $\begin{array}{l}\text { Identities (I), } \\
\text { Query cover (QC) }\end{array}$ \\
\hline \multirow[t]{10}{*}{ P. camelliae } & MUCC0059 $^{a}$ & Camellia & Japan & $\mathrm{AB} 454290 \Delta$ & Guignardia philoprina & MUCC0012 $^{\mathrm{b}}$ & AB454262 & $100 \%$ (I), 100\% (QC) \\
\hline & & japonica var. & & & Guignardia mangiferae & MUCC0122 b & AB454315 & $99.92 \%(\mathrm{I}), 100 \%(\mathrm{QC})$ \\
\hline & & hortensis & & & Phyllosticta fallopiae & MUCC0113 b & AB454307 & $99.92 \%(\mathrm{I}), 100 \%$ (QC) \\
\hline & & & & & Guignardia philoprina & MUCC0027 b & AB454270 & $99.92 \%(\mathrm{I}), 100 \%(\mathrm{QC})$ \\
\hline & & & & & Guignardia alliacea & MUCC0015 b & AB454264 & $99.92 \%(\mathrm{I}), 100 \%(\mathrm{QC})$ \\
\hline & & & & $\mathrm{AB} 704223 \bullet$ & Phyllosticta sphaeropsoidea & MUCC0112 $^{\mathrm{a}}$ & AB704227 & $100 \%(\mathrm{I}), 100 \%(\mathrm{QC})$ \\
\hline & & & & & Guignardia sawadae & MUCC0066 $^{\mathrm{a}}$ & AB704225 & $100 \%$ (I), $100 \%$ (QC) \\
\hline & & & & & Phyllosticta harai & MUCC0043 ${ }^{a}$ & AB704219 & $100 \%$ (I), $100 \%$ (QC) \\
\hline & & & & & Guignardia mangiferae & MUCC0030 ${ }^{a}$ & AB704215 & $100 \%(\mathrm{I}), 99 \%$ (QC) \\
\hline & & & & & Guignardia mangiferae & MUCC0122 ${ }^{a}$ & AB704231 & $99.6 \%(\mathrm{I}), 100 \%(\mathrm{QC})$ \\
\hline
\end{tabular}

*Gene: ${ }^{\boldsymbol{}} \mathrm{ITS},{ }^{\bullet}$ actin

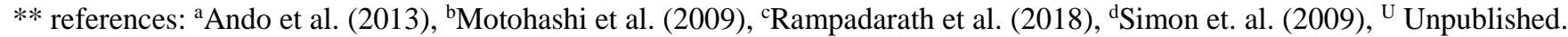

Table 6 GenBank BLAST search results (top five) of 17 strains excluded from Phyllosticta in this study.

\begin{tabular}{|c|c|c|c|c|c|c|c|c|}
\hline \multirow[b]{2}{*}{ Taxon } & \multirow[b]{2}{*}{ Strain } & \multirow[b]{2}{*}{ Host } & \multirow[b]{2}{*}{ Country } & \multirow[b]{2}{*}{$\begin{array}{l}\text { GenBank } \\
\text { accession no.* }\end{array}$} & \multicolumn{4}{|c|}{ GenBank BLAST search against type material } \\
\hline & & & & & $\begin{array}{l}\text { Species identified } \\
\text { (top BLAST results) }\end{array}$ & Strain & $\begin{array}{l}\text { GenBank } \\
\text { accession no. }\end{array}$ & $\begin{array}{l}\text { Identities (I), } \\
\text { Query cover (QC) }\end{array}$ \\
\hline \multirow[t]{5}{*}{ P. alcides } & P3-4 ${ }^{\mathrm{s}}$ & Indetermined & Japan & KF590155ם & Paraphoma radicina & CBS 111.79 & EU754191 & $\mathrm{I}=99.76 \% / \mathrm{QC}=100 \%$ \\
\hline & & & & & Paraphoma rhaphiolepidis & CBS 142524 & KY979813 & $\mathrm{I}=99.64 \% / \mathrm{QC}=100 \%$ \\
\hline & & & & & Paraphoma radicina & CBS 111.79 & KF251676 & $\mathrm{I}=99.76 \% / \mathrm{QC}=98 \%$ \\
\hline & & & & & Neosetophoma rosarum & MFLU 17-0308 & MG829036 & $\mathrm{I}=99.04 \% / \mathrm{QC}=100 \%$ \\
\hline & & & & & Neosulcatispora agaves & СРС 26407 & KT950867 & $\mathrm{I}=99.04 \% / \mathrm{QC}=100 \%$ \\
\hline \multirow[t]{7}{*}{ P. artocarpina } & $B 5^{d}$ & $\begin{array}{l}\text { Artocarpus } \\
\text { heterophyllus }\end{array}$ & India & $\begin{array}{l}\text { AY042930 } \Delta \\
\text { (ITS2) }\end{array}$ & $\begin{array}{l}\text { Neomicrosphaeropsis } \\
\text { alhagi-pseudalhagi }\end{array}$ & TASM 6134 & MH069664 & $\mathrm{I}=99.54 \% / \mathrm{QC}=100 \%$ \\
\hline & & & & & Epicoccum proteae & CBS 114179 & MH862956 & $\mathrm{I}=99.54 \% / \mathrm{QC}=100 \%$ \\
\hline & & & & & Epicoccum poae & CGMCC 3.18363 & NR_158266 & $\mathrm{I}=99.54 \% / \mathrm{QC}=100 \%$ \\
\hline & & & & & Epicoccum layuense & CGMCC 3.18362 & NR_158265 & $\mathrm{I}=99.54 \% / \mathrm{QC}=100 \%$ \\
\hline & & & & & Epicoccum hordei & CGMCC 3.18360 & NR_158263 & $\mathrm{I}=99.54 \% / \mathrm{QC}=100 \%$ \\
\hline & & & & AY042929 A & Epicoccum rosae & MFLU 15-3639 & NR_157517 & $\mathrm{I}=100.00 \% / \mathrm{QC}=100 \%$ \\
\hline & & & & (ITS1) & Epicoccum tritici & MFLUCC 16-0276 & KX926426 & $\mathrm{I}=100.00 \% / \mathrm{QC}=100 \%$ \\
\hline
\end{tabular}


Table 6 Continued.

\begin{tabular}{|c|c|c|c|c|c|c|c|c|}
\hline \multirow[b]{2}{*}{ Taxon } & \multirow[b]{2}{*}{ Strain } & \multirow[b]{2}{*}{ Host } & \multirow[b]{2}{*}{ Country } & \multirow[b]{2}{*}{$\begin{array}{l}\text { GenBank } \\
\text { accession no.* }\end{array}$} & \multicolumn{4}{|c|}{ GenBank BLAST search against type material } \\
\hline & & & & & $\begin{array}{l}\text { Species identified } \\
\text { (top BLAST results) }\end{array}$ & Strain & $\begin{array}{l}\text { GenBank } \\
\text { accession } \\
\text { no. }\end{array}$ & $\begin{array}{l}\text { Identities (I), } \\
\text { Query cover (QC) }\end{array}$ \\
\hline \multirow{7}{*}{ P. caprifolii } & \multirow{7}{*}{$\mathrm{F} 23^{\mathrm{u}}$} & \multirow{7}{*}{ Ferula } & & \multirow{7}{*}{$\mathrm{KF} 887044 \boldsymbol{\Delta}$} & Epicoccum dendrobii & CGMCC 3.18359 & NR_158261 & $\mathrm{I}=100.00 \% / \mathrm{QC}=100 \%$ \\
\hline & & & & & Epicoccum layuense & CGMCC 3.18362 & NR_158265 & $\mathrm{I}=100.00 \% / \mathrm{QC}=100 \%$ \\
\hline & & & & & Ascochyta rabiei & CBS 237.37 & MG786925 & $\mathrm{I}=99.30 \% / \mathrm{QC}=100 \%$ \\
\hline & & & & & Macroventuria wentii & CBS 526.71 & MH860250 & $\mathrm{I}=99.38 \% / \mathrm{QC}=100 \%$ \\
\hline & & & & & Vacuiphoma bulgarica & CBS 357.84 & MH861745 & $\mathrm{I}=99.18 \% / \mathrm{QC}=100 \%$ \\
\hline & & & & & Vacuiphoma oculihominis & UTHSC DI16-308 & NR_158281 & $\mathrm{I}=98.98 \% / \mathrm{QC}=100 \%$ \\
\hline & & & & & Didymellaceae & 2 NV-2016 & LT592954 & $\mathrm{I}=98.98 \% / \mathrm{QC}=100 \%$ \\
\hline \multirow{5}{*}{ P. citrullina } & \multirow{4}{*}{ LrBF12 } & \multirow{5}{*}{$\begin{array}{l}\text { Bulb of } \\
\text { Lycoris } \\
\text { radiata }\end{array}$} & \multirow{4}{*}{ China } & \multirow{4}{*}{ MG543730 $\Delta$} & Ascochyta phacae & CBS 184.55 & MH857437 & $\mathrm{I}=98.77 \% / \mathrm{QC}=100 \%$ \\
\hline & & & & & Stagonosporopsis ajacis & CBS 177.93 & NR_160049 & $\mathrm{I}=99.79 \% / \mathrm{QC}=91 \%$ \\
\hline & & & & & Stagonosporopsis ajacis & CBS 177.93 & GU237791 & $\mathrm{I}=99.79 \% / \mathrm{QC}=91 \%$ \\
\hline & & & & & Stagonosporopsis lupini & CBS 101494 & NR_160205 & $\mathrm{I}=98.40 \% / \mathrm{QC}=95 \%$ \\
\hline & \multirow{5}{*}{ LrBF13 } & & \multirow{5}{*}{ China } & \multirow{5}{*}{ MG543731 $\Delta$} & $\begin{array}{l}\text { Stagonosporopsis } \\
\text { valerianellae }\end{array}$ & CBS 329.67 & NR_160109 & $\mathrm{I}=98.40 \% / \mathrm{QC}=95 \%$ \\
\hline \multirow{4}{*}{ P. citrullina } & & \multirow{4}{*}{$\begin{array}{l}\text { Bulb of } \\
\text { Lycoris } \\
\text { radiata }\end{array}$} & & & Stagonosporopsis lupini & CBS 101494 & MH862737 & $\mathrm{I}=98.40 \% / \mathrm{QC}=95 \%$ \\
\hline & & & & & Stagonosporopsis ajacis & CBS 177.93 & NR_160049 & $\mathrm{I}=99.59 \% / \mathrm{QC}=93 \%$ \\
\hline & & & & & Stagonosporopsis lupini & CBS 101494 & NR_160205 & $\mathrm{I}=99.59 \% / \mathrm{QC}=93 \%$ \\
\hline & & & & & $\begin{array}{l}\text { Stagonosporopsis } \\
\text { valerianellae }\end{array}$ & CBS 329.67 & NR_160109 & $\mathrm{I}=98.22 \% / \mathrm{QC}=97 \%$ \\
\hline \multirow{6}{*}{ P. coryli } & \multirow{6}{*}{ CTF324 аa } & \multirow{6}{*}{ Hazel nut } & & \multirow{6}{*}{$\mathrm{KC} 196068 \boldsymbol{\Delta}$} & Stagonosporopsis lupini & CBS 101494 & MH862737 & $\mathrm{I}=98.22 \% / \mathrm{QC}=97 \%$ \\
\hline & & & & & $\begin{array}{l}\text { Stagonosporopsis } \\
\text { valerianellae }\end{array}$ & CBS 329.67 & MH858985 & $\mathrm{I}=98.22 \% / \mathrm{QC}=97 \%$ \\
\hline & & & & & Peyronellaea prosopidis & СРС 21698 & NR_137836 & $\mathrm{I}=99.39 \% / \mathrm{QC}=100 \%$ \\
\hline & & & & & Didymella keratinophila & UTHSC DI16-200 & NR_158275 & $\mathrm{I}=99.18 \% / \mathrm{QC}=100 \%$ \\
\hline & & & & & Didymella sp. & UTHSC DI16-200 & LT592901 & $\mathrm{I}=99.18 \% / \mathrm{QC}=100 \%$ \\
\hline & & & & & Didymella pedeiae & CBS 124517 & MH863383 & $\mathrm{I}=98.98 \% / \mathrm{QC}=100 \%$ \\
\hline & & & & & $\begin{array}{l}\text { Didymella } \\
\text { microchlamydospora }\end{array}$ & CBS 105.95 & MH862504 & $\mathrm{I}=98.98 \% / \mathrm{QC}=100 \%$ \\
\hline P. flevolandica & $\begin{array}{l}\text { AFTOL- } \\
\text { ID } 1786^{\text {u }}\end{array}$ & - & & DQ678090匹 & Lolia dictyospora & CBS H-22131 & KU726000 & $\mathrm{I}=98.98 \% / \mathrm{QC}=100 \%$ \\
\hline
\end{tabular}


Table 6 Continued.

\begin{tabular}{|c|c|c|c|c|c|c|c|c|}
\hline \multirow[b]{2}{*}{ Taxon } & \multirow[b]{2}{*}{ Strain } & \multirow[b]{2}{*}{ Host } & \multirow[b]{2}{*}{ Country } & \multirow[b]{2}{*}{$\begin{array}{l}\text { GenBank } \\
\text { accession no.* }\end{array}$} & \multicolumn{4}{|c|}{ GenBank BLAST search against type material } \\
\hline & & & & & $\begin{array}{l}\text { Species identified } \\
\text { (top BLAST results) }\end{array}$ & Strain & $\begin{array}{l}\text { GenBank } \\
\text { accession no. }\end{array}$ & $\begin{array}{l}\text { Identities (I), } \\
\text { Query cover (QC) }\end{array}$ \\
\hline & & & & & $\begin{array}{l}\text { Lindgomyces } \\
\text { breviappendiculatus }\end{array}$ & HHUF 28194 & NG_056267 & $\mathrm{I}=98.82 \% / \mathrm{QC}=100 \%$ \\
\hline & & & & & $\begin{array}{l}\text { Lindgomyces } \\
\text { breviappendiculatus }\end{array}$ & KT1399 & AB521749 & $\mathrm{I}=98.82 \% / \mathrm{QC}=100 \%$ \\
\hline & & & & & Lindgomyces apiculatus & KT1108 & NG_055737 & $\mathrm{I}=98.74 \% / \mathrm{QC}=100 \%$ \\
\hline & & & & & Lindgomyces ingoldianus & ATCC 200398 & NG_042321 & $\mathrm{I}=98.66 \% / \mathrm{QC}=100 \%$ \\
\hline \multirow[t]{5}{*}{ P. flevolandica } & CBS & Soil & Netherla & DQ377927ø & Lindgomyces angustiascus & ILL A640-1a & NG_042721 & $\mathrm{I}=98.43 \% / \mathrm{QC}=100 \%$ \\
\hline & $998.72^{\mathrm{g}}$ & & nds & & $\begin{array}{l}\text { Lindgomyces } \\
\text { lemonweirensis }\end{array}$ & ILL 40793 & NG_042580 & $\mathrm{I}=98.32 \% / \mathrm{QC}=100 \%$ \\
\hline & & & & & $\begin{array}{l}\text { Lindgomyces } \\
\text { pseudomadisonensis }\end{array}$ & KT 2742 & LC149916 & $\mathrm{I}=98.08 \% / \mathrm{QC}=99 \%$ \\
\hline & & & & & Lindgomyces madisonensis & CBS 140367 & MH878155 & $\mathrm{I}=99.08 \% / \mathrm{QC}=99 \%$ \\
\hline & & & & & Lolia dictyospora & CBS H-22131 & KU726000 & $\mathrm{I}=99.18 \% / \mathrm{QC}=95 \%$ \\
\hline \multirow[t]{5}{*}{ P. heveae } & NW197 u & Indetermined & China & EU520128 A & Didymella keratinophila & $\begin{array}{l}\text { UTHSC DI16- } \\
200\end{array}$ & NR_158275 & $\mathrm{I}=96.64 \% \% / \mathrm{QC}=96 \%$ \\
\hline & & & & & Didymella sp. & $1 \mathrm{NV}-2016$ & LT592901 & $\mathrm{I}=96.64 \% \% / \mathrm{QC}=96 \%$ \\
\hline & & & & & Didymella sancta & CBS 281.83 & MH861588 & $\mathrm{I}=96.25 \% / \mathrm{QC}=96 \%$ \\
\hline & & & & & $\begin{array}{l}\text { Didymella } \\
\text { microchlamydospora }\end{array}$ & CBS 105.95 & MH862504 & $\mathrm{I}=96.07 \% / \mathrm{QC}=96 \%$ \\
\hline & & & & & Epicoccum huancayense & CBS 105.80 & MH861244 & $\mathrm{I}=96.07 \% / \mathrm{QC}=95 \%$ \\
\hline \multirow[t]{5}{*}{ P. jasmini } & TS08- & Jasminum & China & $\mathrm{AB} 470839 \boldsymbol{\Delta}$ & Epicoccum huancayense & CBS 105.80 & MH861244 & $\mathrm{I}=98.12 \% / \mathrm{QC}=98 \%$ \\
\hline & $19-2^{\text {u }}$ & nudiflorum & & & Neodidymella thailandicum & MFLU 11-0176 & NR_156400 & $\mathrm{I}=98.11 \% / \mathrm{QC}=98 \%$ \\
\hline & & & & & Stagonosporopsis lupini & CBS 101494 & NR_160205 & $\mathrm{I}=97.93 \% / \mathrm{QC}=97 \%$ \\
\hline & & & & & Ascochyta phacae & CBS 184.55 & NR_135942 & $\mathrm{I}=97.05 \% / \mathrm{QC}=100 \%$ \\
\hline & & & & & Ascochyta phacae & CBS 184.55 & EU167570 & $\mathrm{I}=97.05 \% / \mathrm{QC}=100 \%$ \\
\hline \multirow[t]{4}{*}{ P. jasmini } & 6259 u & Artemisia & China & JN903927 A & Boeremia trachelospermi & CGMCC 3.18222 & NR_158252 & $\mathrm{I}=99.58 \% / \mathrm{QC}=92 \%$ \\
\hline & & аппиа & & & $\begin{array}{l}\text { Boeremia exigua var. } \\
\text { heteromorpha }\end{array}$ & CBS 443.94 & NR_158238 & $\mathrm{I}=99.58 \% / \mathrm{QC}=92 \%$ \\
\hline & & & & & $\begin{array}{l}\text { Boeremia exigua var. } \\
\text { pseudolilacis }\end{array}$ & CBS 101207 & NR_158232 & $\mathrm{I}=99.58 \% / \mathrm{QC}=92 \%$ \\
\hline & & & & & Boeremia exigua var. populi & CBS 100167 & NR_158231 & $\mathrm{I}=99.58 \% / \mathrm{QC}=92 \%$ \\
\hline
\end{tabular}


Table 6 Continued.

\begin{tabular}{|c|c|c|c|c|c|c|c|c|}
\hline \multirow[b]{2}{*}{ Taxon } & \multirow[b]{2}{*}{ Strain } & \multirow[b]{2}{*}{ Host } & \multirow[b]{2}{*}{$\begin{array}{l}\text { Countr } \\
\mathbf{y}\end{array}$} & \multirow[b]{2}{*}{$\begin{array}{l}\text { GenBank } \\
\text { accession no.* }\end{array}$} & \multicolumn{4}{|c|}{ GenBank BLAST search against type material } \\
\hline & & & & & $\begin{array}{l}\text { Species identified } \\
\text { (top BLAST results) }\end{array}$ & Strain & $\begin{array}{l}\text { GenBank } \\
\text { accession } \\
\text { no. }\end{array}$ & $\begin{array}{l}\text { Identities (I), } \\
\text { Query cover (QC) }\end{array}$ \\
\hline \multirow{6}{*}{ P. juglandis } & & & & & Boeremia strasseri & CBS 126.93 & NR_135985 & $\mathrm{I}=99.37 \% / \mathrm{QC}=92 \%$ \\
\hline & $\mathrm{H} 2{ }^{\mathrm{u}}$ & Indetermined & & $\mathrm{KC} 168088 \boldsymbol{\Delta}$ & Didymella rosea & BRIP 50788 & NR_136125 & $\mathrm{I}=99.39 \% / \mathrm{QC}=100 \%$ \\
\hline & & & & & Phoma segeticola & CGMCC 3.17489 & КР330443 & $\mathrm{I}=100.00 \% / \mathrm{QC}=97 \%$ \\
\hline & & & & & Didymella suiyangensis & CGMCC 3.18352 & NR_158260 & $\mathrm{I}=99.79 \% / \mathrm{QC}=97 \%$ \\
\hline & & & & & Didymella suiyangensis & LC7439 & KY742089 & $\mathrm{I}=99.79 \% / \mathrm{QC}=97 \%$ \\
\hline & & & & & Didymella brunneospora & CBS 115.58 & КТ389505 & $\mathrm{I}=99.37 \% / \mathrm{QC}=97 \%$ \\
\hline \multirow[t]{5}{*}{ P. ligustri } & TS08-20-1 & Ligustrum sp. & China & $\mathrm{AB} 470841 \boldsymbol{\Delta}$ & Ascochyta rabiei & CBS 237.37 & EU167600 & $\mathrm{I}=97.79 \% / \mathrm{QC}=100 \%$ \\
\hline & & & & & Ascochyta phacae & CBS 184.55 & NR_135942 & $\mathrm{I}=97.61 \% / \mathrm{QC}=100 \%$ \\
\hline & & & & & Epicoccum huancayense & CBS 105.80 & MH861244 & $\mathrm{I}=97.94 \% / \mathrm{QC}=97 \%$ \\
\hline & & & & & $\begin{array}{l}\text { Didymella } \\
\text { microchlamydospora }\end{array}$ & CBS 105.95 & MH862504 & $\mathrm{I}=97.23 \% / \mathrm{QC}=99 \%$ \\
\hline & & & & & Didymella keratinophila & UTHSC DI16-200 & NR_158275 & $\mathrm{I}=97.39 \% / \mathrm{QC}=98 \%$ \\
\hline \multirow[t]{5}{*}{$P$. papayae } & $\mathrm{T} 150^{\mathrm{u}}$ & Indetermined & China & FJ462748 $\boldsymbol{\Delta}$ & Diaporthe mahothocarpus & CGMCC 3.15181 & NR_147522 & $\mathrm{I}=99.81 \% / \mathrm{QC}=91 \%$ \\
\hline & & & & & Diaporthe toxicodendri & TFM FP-10740 & NR_158416 & $\mathrm{I}=96.52 \% / \mathrm{QC}=98 \%$ \\
\hline & & & & & Diaporthe toxicodendri & FFPRI420987 & LC275192 & $\mathrm{I}=96.52 \% / \mathrm{QC}=98 \%$ \\
\hline & & & & & Diaporthe alnea & CBS 146.46 & NR_147525 & $\mathrm{I}=96.83 \% / \mathrm{QC}=97 \%$ \\
\hline & & & & & Diaporthe bohemiae & CPC 28222 & NR_164425 & $\mathrm{I}=96.45 \% / \mathrm{QC}=97 \%$ \\
\hline \multirow[t]{5}{*}{ P. papayae } & $7 \mathrm{AJ}-10^{\mathrm{u}}$ & Mulberry & & KR708979 & Diaporthe mahothocarpus & CGMCC 3.15181 & NR_147522 & $\mathrm{I}=99.56 \% / \mathrm{QC}=79 \%$ \\
\hline & & & & & Diaporthe toxicodendri & TFM FP-10740 & NR_158416 & $\mathrm{I}=96.85 \% / \mathrm{QC}=83 \%$ \\
\hline & & & & & Diaporthe toxicodendri & FFPRI420987 & LC275192 & $\mathrm{I}=96.85 \% / \mathrm{QC}=83 \%$ \\
\hline & & & & & Diaporthe alnea & CBS 146.46 & NR_147525 & $\mathrm{I}=96.80 \% / \mathrm{QC}=82 \%$ \\
\hline & & & & & Diaporthe bohemiae & СРС 28222 & NR_164425 & $\mathrm{I}=97.00 \% / \mathrm{QC}=82 \%$ \\
\hline \multirow[t]{5}{*}{ P. populina } & NW584 u & Indetermined & China & EU520202 A & Epicoccum huancayense & CBS 105.80 & MH861244 & $\mathrm{I}=96.99 \% / \mathrm{QC}=97 \%$ \\
\hline & & & & & Neodidymella thailandicum & MFLU 11-0176 & NR_156400 & $\mathrm{I}=96.82 \% / \mathrm{QC}=97 \%$ \\
\hline & & & & & Stagonosporopsis lupini & CBS 101494 & NR_160205 & $\mathrm{I}=96.85 \% / \mathrm{QC}=97 \%$ \\
\hline & & & & & Boeremia trachelospermi & CGMCC 3.18222 & NR_158252 & $\mathrm{I}=100.00 \% / \mathrm{QC}=88 \%$ \\
\hline & & & & & $\begin{array}{l}\text { Boeremia exigua var. } \\
\text { heteromorpha }\end{array}$ & CBS 443.94 & NR_158238 & $\mathrm{I}=100.00 \% / \mathrm{QC}=88 \%$ \\
\hline
\end{tabular}


Table 6 Continued.

\begin{tabular}{|c|c|c|c|c|c|c|c|c|}
\hline \multirow[b]{2}{*}{ Taxon } & \multirow[b]{2}{*}{ Strain } & \multirow[b]{2}{*}{ Host } & \multirow[b]{2}{*}{ Country } & \multirow[b]{2}{*}{$\begin{array}{l}\text { GenBank } \\
\text { accession no.* }\end{array}$} & \multicolumn{4}{|c|}{ GenBank BLAST search against type material } \\
\hline & & & & & $\begin{array}{l}\text { Species identified } \\
\text { (top BLAST results) }\end{array}$ & Strain & $\begin{array}{l}\text { GenBank } \\
\text { accession } \\
\text { no. }\end{array}$ & $\begin{array}{l}\text { Identities (I), } \\
\text { Query cover (QC) }\end{array}$ \\
\hline \multirow[t]{15}{*}{ P. sojicola } & CBS & Indetermined & Germany & EU573029 A & Epicoccum proteae & CBS 114179 & NR_158240 & $\mathrm{I}=98.04 \% / \mathrm{QC}=100 \%$ \\
\hline & $301.39^{p}$ & & & & Neodidymella thailandicum & MFLU 11-0176 & NR_156400 & $\mathrm{I}=97.85 \% / \mathrm{QC}=100 \%$ \\
\hline & & & & & Epicoccum huancayense & CBS 105.80 & MH861244 & $\mathrm{I}=97.84 \% / \mathrm{QC}=100 \%$ \\
\hline & & & & & Stagonosporopsis lupini & CBS 101494 & NR_160205 & $\mathrm{I}=97.65 \% / \mathrm{QC}=99 \%$ \\
\hline & & & & & Boeremia trachelospermi & CGMCC 3.18222 & NR_158252 & $\mathrm{I}=99.79 \% / \mathrm{QC}=93 \%$ \\
\hline & & & & MH867524ロ & Stagonosporopsis pini & $\mathrm{C} 452$ & MK348019 & $\mathrm{I}=97.74 \% / \mathrm{QC}=99 \%$ \\
\hline & & & & & Didymella vitalbina & CBS 123707 & MH874853 & $\mathrm{I}=97.63 \% / \mathrm{QC}=99 \%$ \\
\hline & & & & & Didymella anserina & CBS 285.29 & MH866534 & $\mathrm{I}=97.63 \% / \mathrm{QC}=99 \%$ \\
\hline & & & & & $\begin{array}{l}\text { Briansuttonomyces } \\
\text { eucalypti }\end{array}$ & CBS 114879 & KU728519 & $\mathrm{I}=97.63 \% / \mathrm{QC}=99 \%$ \\
\hline & & & & & Phoma tamaricicola & MFLUCC 14-0602 & KM408754 & $\mathrm{I}=97.63 \% / \mathrm{QC}=99 \%$ \\
\hline & & & & EU5953560 & $\begin{array}{l}\text { Boeremia exigua var. } \\
\text { pseudolilacis }\end{array}$ & CBS 101207 & KY484710 & $\mathrm{I}=93.87 \% / \mathrm{QC}=88 \%$ \\
\hline & & & & & Boeremia exigua var. populi & CBS 100167 & KY484706 & $\mathrm{I}=90.84 \% / \mathrm{QC}=88 \%$ \\
\hline & & & & & $\begin{array}{l}\text { Boeremia exigua var. } \\
\text { heteromorpha }\end{array}$ & CBS 443.94 & KY484700 & $\mathrm{I}=90.84 \% / \mathrm{QC}=88 \%$ \\
\hline & & & & & Boeremia strasseri & CBS 126.93 & KY484735 & $\mathrm{I}=90.04 \% / \mathrm{QC}=88 \%$ \\
\hline & & & & & Boeremia noackiana & CBS 101203 & KY484728 & $\mathrm{I}=85.77 \% / \mathrm{QC}=88 \%$ \\
\hline
\end{tabular}

\section{${ }^{*}$ Gene: ${ }^{\mathbf{\Delta}}$ ITS, $\mathbf{\text { LSU, }}{ }^{\circ}$ efla}

\section{Acknowledgements}

This work was supported by National Chiayi University, Taiwan; the Mushroom Research Foundation (MRF), Chiang Rai, Thailand; the Thailand Research Fund and Mae Fah Luang University entitled "Biodiversity, Phylogeny and role of fungal endophytes on above parts of Rhizophora apiculata and Nypa fruticans" (Grant number: RSA5980068) and Mae Fah Luang University for a grant "Diseases of mangrove trees and maintenance of good forestry practice” (Grant number: 60201000201) for support. We would like to thank Danushka Tennakoon, Anurudda Karunarathna, HsiuJung Chien, Hsin-Yi Peng, Yi-Chia Chiu, Hsiang-Yu Lin, Wu-Ting Tsai, and Chih-Hao Hsu for general assistance. 


\section{References}

Adamska I. 2001 - Microscopic fungus-like organisms and fungi of the Slowinski National Park. II. (NW Poland). Acta Mycologica 36, 31-65.

Adesemoye AO, Mayorquin JS, Wang DH, Twizeyimana M et al. 2014 - Identification of species of Botryosphaeriaceae causing bot gummosis in Citrus in California. Plant Disease 98, 55-61.

Ahmad S. 1969 - Fungi of West Pakistan. Biological Society of Pakistan Monograph. 5 (Sup.1), 1110.

Ahmad S, Iqbal SH, Khalid AN. 1997 - Fungi of Pakistan. Sultan Ahmad Mycological Society of Pakistan, 248 pages.

Alfieri Jr SA, Langdon KR, Wehlburg C, Kimbrough JW. 1984 - Index of Plant Diseases in Florida (Revised). Florida Department of Agriculture and Consumer Services, Division of Plant Industry Bull 11, 1-389.

Al-Hatmi AMS, Meis JF, de Hoog GS 2016 - Fusarium: molecular diversity and intrinsic drug resistance. PLOS Pathogens 12:e1005464.

Ali MS, Saikia UN. 1997 - Coelomycetes of Assam - I. Indian Phytopathology 50, 200-205.

Alias SA, Jones EBG. 2009 - Marine fungi from mangrovesof Malaysia. Institute Ocean and Earth Sciences, University of Malaya, Kuala Lumpur, Malaysia, pp. 108.

Alias SA, Zainuddin N, Jones EBG. 2010 - Biodiversity of marine fungi in Malaysian mangroves. Botanica Marina 53, 545-554.

Alvarez MG. 1976 - Primer catalogo de enfermedades de plantas Mexicanas. Fitofilo 71, 1-169.

Anderson PJ. 1919 - Index to American species of Phyllosticta. Mycologia 11, 66-79.

Ando Y, Motohashi K, Yaguchi Y. 2013 - Taxonomic re-examination of Cryptomeria gall disease causing fungus. Japanese Journal of Mycology 54, 15-26.

Anonymous. 1960 - Index of plant diseases in the United States. USDA Agriculture handbook 165, 1-531.

Anonymous. 1928 - The Marlborough foray. Transactions of the British Mycological Society 13, 145-150.

Anonymous. 1931-1970. California fungi. Nos. 1-1325. Exsiccati set, N/A pages.

Anonymous. 1979 - List of plant diseases in Taiwan. Plant Protection Society, Republ of China, 404 pages.

Arzanlou M, Torbati M. 2013 - Phenotypic and molecular characterisation of Colletotrichum acutatum, the casual agent of anthracnose disease on Cornus mas in Iran. Archiv für Phytopathologie und Pflanzenschutz 46, 518-525.

Baayen RP, Bonants P, Verkley G, Carroll GC et al. 2002 - Nonpathogenic isolates of the Citrus black spot fungus, Guignardia citricarpa, identified as a Cosmopolitan endophyte of woody plants, G. mangiferae (Phyllosticta capitalensis). Phytopathology 92, 464-77.

Bai JK. 2000 - Flora fungorum sinicorum. Vol. 15. Sphaeropsidales, Phoma, Phyllosticta. Science Press, Beijing, 255 pages.

Bai JK. 2003 - Flora fungorum sinicorum. Vol. 17. Sphaeropsidales, Ascochyta, Septoria. Science Press, Beijing, 372 pages.

Barnard EL. 2000 - Inonotus root and butt rot of pines in Florida. Plant Pathology Circular 403.

Barr ME. 1970 - Some amerosporous ascomycetes on Ericaceae and Empetraceae. Mycologia 62, 377-394.

Bassimba DDM, Nzambi N, Paixao MIS, Katula IG, Vicent A. 2018 - First report of citrus black spot caused by Phyllosticta citricarpa in Angola. Plant Disease 102, 683.

Beger M, Grantham HS, Pressey RL, Wilson KA et al. 2010 - Conservation planning for connectivity across marine, freshwater, and terrestrial realms. Biological Conservation 143, 565-575.

Begoude BAD, Slippers B, Wingfeld MJ, Roux J. 2010 - Botryosphaeriaceae associated with Terminalia catappa in Cameroon, South Africa and Madagascar. Mycological Progress 9, 101-123. 
Bengtsson-Palme J, Ryberg M, Hartmann M, Branco S et al. 2013 - Improved software detection and extraction of ITS1 and ITS2 from ribosomal ITS sequences of fungi and other eukaryotes for analysis of environmental sequencing data. Methods in Ecology and Evolution 4, 914919.

Benjamin CR, Slot A. 1969 - Fungi of Haiti. Sydowia 23, 125-163.

Bissett J, Darbyshire SJ. 1984a - Phyllosticta gaultheriae. Fungi Canadenses 275, 1-2.

Bissett J, Darbyshire SJ. 1984b - Phyllosticta hamamelidis. Fungi Canadenses 276, 1-2.

Bissett J, Darbyshire SJ. 1984c - Phyllosticta minima. Fungi Canadenses 277, 1-2.

Bissett J, Darbyshire SJ. 1984d - Phyllosticta pyrolae. Fungi Canadenses 279, 1-2.

Blain WL. 1931 - A list of diseases of economic plants in Alabama. Mycologia 23, 300-304.

Boa E, Lenné J. 1994 - Diseases of Nitrogen fixing trees in developing countries. An annotated list. Natural Resources Inst., Kent, United Kingdom, 82 pages.

Bobev S. 2009 - Reference guide for the diseases of cultivated plants (translated from Russian). Unknown journal or publisher, 466 pages.

Boewe GH. 1964 - Some plant diseases new to Illinois. Plant Disease Reporter 48, 866-870.

Bose SK, Roy AJ, Jain VB. 1970 - A new leaf-spot diease of ivy (Hedera helix Linn.) caused by Phyllostictina hederae Bose, Roy and Jain sp. nov. Progressive Horticulture 2, 75-77.

Boughalleb-M'Hamdi N, Fathallah A, Benfradj N et al. 2020 - First report of citrus black spot disease caused by Phyllosticta citricarpa on Citrus limon and C. sinensis in Tunisia. New Disease Reports 41, 8.

Brenckle JF. 1918 - North Dakota fungi - II. Mycologia 10, 199-221.

Brittingham RL, O’Brien MJ. 1978 - Occurrence of Phyllosticta cryptomeriae on Cryptomeria japonica in the United States. Plant Disease Reporter 62, 152-153.

Brunaud P. 1890 - Sphaeropsidees recoltees jusqu'a ce jour dans la Charente-Inferieure. Annales de la Société royale des sciences médicales et naturelles 26, 51-140.

Camara MS. 1930 - Contributiones ad mycofloram Lusitaniae. Anais Instituto Superior de Agronomia 3, 59-141.

Cannon PF, Damm U, Johnston PR, Weir BS. 2012 - Colletotrichum current status and future directions. Studies in Mycology 73, 181-213.

Cannon PF, Hawksworth DL, Sherwood-Pike MA. 1985 - The British Ascomycotina. An annotated checklist. Commonwealth Mycological Institute, Kew, Surrey, England, 302 pages.

Carbone I, Kohn LM. 1999 - A method for designing primer sets for speciation studies in filamentous ascomycetes. Mycologia 91, 553-556.

Cash EK. 1953 - A record of the fungi named by J.B. Ellis (Part 2). U.S.D.A. Special Publication 2, 167-345.

Cash EK, Watson AJ. 1955 - Some fungi on Orchidaceae. Mycologia 47, 729-747.

Chacón S, Carrion G. 1984 - New records of phytopathogenic ascomycetes in Mexico. Boletin de la Sociedad Mexicana de Micologia 19, 193-199.

Chen CC. 1967 - Phyllosticta eugeniae. Botanical Bulletin- Academia Sinica Taipei, N.S. 8:142

Chen MM. 2002 - Forest fungi phytogeography, forest fungi phytogeography of China, North America, and Siberia and international quarantine of tree pathogens. Pacific Mushroom Research and Education Center, Sacramento, California, 469 pages.

Chen SF, Morgan DP, Michailides TJ. 2014 - Botryosphaeriaceae and Diaporthaceae associated with panicle and shoot blight of pistachio in California, USA. Fungal Diversity 67, 157-179.

Cheng LL, Thangaraj K, Deng C, Deng WW, Zhang ZZ. 2019 - Phyllosticta capitalensis causes leaf spot on tea plant (Camellia sinensis) in China. Plant Disease 103, 2964-2965.

Cho WD, Shin HD. 2004 - List of plant diseases in Korea. Fourth edition. Korean Society of Plant Pathology, 779 pages.

Ciferri R. 1929 - La esterilización de los semilleros de tabaco con los compuestos mercuroorganicos Bayer. Review of Agricultural Santo Domingo 30, 4-5.

Ciferri R. 1961 - Mycoflora domingensis integrata. Quaderno 19, 1-539. 
Clinton GP. 1908 - Report of the Botanist 1908. Connecticut Agricultural Experiment Station 12, 849-907.

Clinton GP. 1934 - Plant pest handbook for connecticut II. Diseases and injuries. Storrs Agricultural Experiment Station 358, 149-329.

Conners IL. 1967 - An annotated index of plant diseases in Canada and fungi recorded on plants in Alaska, Canada and Greenland. Research Branch of Canadian Department of Agriculture 1251, 1-381.

Cooke WB. 1969 - The 1965 Illinois foray. Mycologia 61, 817-822.

Cooke WB. 1978 - The 1973 Massachusetts foray. Mycologia 69, 1226-1231.

Costa MEA, Camara MS. 1952 - Species aliquae mycologicae Lusitaniae. Portugaliae Acta Biologica (B) 3, 294-307.

Crous PW, Denman S, Taylor JE, Swart L et al. 2013 - Cultivation and disease of Proteaceae, Leucadendron, Leucospermum, and Protea, Second edition. CBS Biodiversity 13, 360.

Crous PW, Denman S, Taylor JE, Swart L, Palm ME. 2004 - Cultivation and diseases of Proteaceae, Leucadendron, Leucospermum and Protea. Centraalbureau voor Schimmelcultures, Utrecht, 227 pages.

Crous PW, Knox-Davies PS, Wingfield MJ. 1989 - A list of Eucalyptus leaf fungi and their potential importance to South African Forestry. South African Forestry Journal 149, 17-29.

Crous PW, Phillips AJL, Baxter AP. 2000 - Phytopathogenic fungi from South Africa. University of Stellenbosch, Department of Plant Pathology Press, 358 pages.

Crous PW, Schumacher RK, Akulov A, Thangavel R et al. 2019 - New and interesting fungi. 2. FUSE 3, 57-134.

Crous PW, Schumacher RK, Wingfield MJ, Akulov A et al. 2018 - New and interesting fungi. 1. FUSE 1, 169-215.

Crous PW, Shivas RG, Wingfield MJ, Summerell BA et al. 2012a - Fungal planet description sheets, 128-153. Persoonia 29, 146-201.

Crous PW, Summerell BA, Shivas RG, Burgess TI et al. 2012b - Fungal planet description sheets, 107-127. Persoonia 28, 138-182.

Crous PW, Summerell BA, Shivas RG, Romberg, M et al. 2011 - Fungal planet description sheets, 92-106. Persoonia 27, 130-162.

Crous PW, Wingfield MJ, Burgess TI, St J Hardy GE et al. 2016 - Fungal planet description sheets, 469-557. Persoonia 37, 218-403.

Crous PW, Wingfield MJ, Burgess TI, Carnegie AJ et al. 2017 - Fungal planet description sheets, 625-715. Persoonia 39, 270-467.

Crous PW, Wingfield MJ, Le Roux J, Richardson DM et al. 2015 - Fungal planet description sheets, 371-399. Persoonia 35, 264-327.

Crous PW, Wingfield MJ, Schumacher RK, Summerell BA et al. 2014 - Fungal planet description sheets, 281-319. Persoonia 33, 212-289.

Cunnington J. 2003 - Pathogenic fungi on introduced plants in Victoria. A host list and literature guide for their identification. Department of Primary Industries, Research Victoria, 57.

da Silva LL, Moreno HLA, Correia HLN, Santana FF, de Queiroz MV. 2020 - Colletotrichum: species complexes, lifestyle, and peculiarities of some sources of genetic variability. Applied Microbiology and Biotechnology 104, 1891-1904.

da Silva M, Weingart Barreto R, Liparini Pereira O. 2012 - Fungal pathogens of 'cat's claws' from Brazil for biocontrol of Macfadyena unguis-cati. Mycotaxon 119, 181-195.

Damm U, Sato T, Alizadeh A, Groenewald JZ, Crous PW. 2019 - The Colletotrichum dracaenophilum, C. magnum and C. orchidearum species complexes. Studies in Mycology 92, 1-46.

Das AK, Nerkar S, Kumar A. 2018 - First report of Phyllosticta citricarpa causing citrus black spot on Citrus sinensis and C. reticulate in India. Plant Disease 102, 1661-1662.

Davis BH. 1946 - Guignardia rhodorae, the perfect stage of Phyllosticta maxima of Rhododendron. Mycologia 38, 40-51. 
de Sousa Dias MR, Lucas MT, Lopes MC. 1987 - Fungi Lusitaniae XXX. Agronomia Lusitana 42, 179-188.

Delsuc F, Brinkmann H, Philippe H. 2005 - Phylogenomics and the reconstruction of the tree of life. Nature Reviews Genetics 6, 361-375.

Dennis RWG. 1978 - British Ascomycetes. J. Cramer, Vaduz, 585 pages.

Dennis RWG. 1986 - Fungi of the Hebrides. Royal Botanic Gardens, Kew, 383 pages.

Dennis RWG, Foister CE. 1942 - List of diseases of economic plants recorded in Scotland. Transactions of the British Mycological Society 25, 266-306.

Dingley JM, Fullerton RA, McKenzie EHC. 1981 - Survey of agricultural pests and diseases. Technical Report Volume 2. Records of Fungi, Bacteria, Algae, and Angiosperms Pathogenic on Plants in Cook Islands, Fiji, Kiribati, Niue, Tonga, Tuvalu, and Western Samoa. F.A.O., 485 pages.

Doidge EM. 1950 - The South African fungi and lichens to the end of 1945. Bothalia 5, 1-1094.

Doilom M, Manawasinghe IS, Jeewon R, Jayawardena RS et al. 2017 - Can ITS sequence data identify fungal endophytes from cultures? A case study from Rhizophora apiculata. Mycosphere 8, 1869-1892.

Driver CH. 1952 - Physalospora ilicis on rotundifolia holly in Georgia. Plant Disease Reporter 36, 355.

Duan CH, Chang CM, Su CC, Pan HR, Wang CC. 2017 - Phyllosticta capitalensis causes black spot of persimmon (Diospyros kaki) fruit in Taiwan. Australasian Plant Disease Notes 12, 36.

Dudka IO, Heluta VP, Tykhonenko YY, Andrianova TV et al. 2004 - Fungi of the Crimean Peninsula (Translated from Russian). M.G. Kholodny Institute of Botany, National Academy of Sciences of Ukraine, 452 pages.

Dzhalagonia KT. 1965 - Parasitic fungi of the main Abkhazian subtropical ornamental plants. Izdvo Metsniereba, Tbilisi, 78 pages.

Earle FS. 1897 - New species of fungi imperfecti from Alabama. Bulletin of the Torrey Botanical Club 24, 28-32.

Ebbels DL, Allen DJ. 1979 - A supplementary and annotated list of plant diseases, pathogens and associated fungi in Tanzania. Phytopathological papers 22, 1-89.

Eglitis M, Goul CJ, Johnson F. 1966 - Fungi found on Ericaceae in the Pacific coastal area. Washington State University Agricultural Experiment Station Bulletin 675, 1-21.

Ellis JB, Everhart BM. 1878-1898 - North American fungi. Exsiccati set Center 1-36, n/a.

Ellis JB, Everhart BM. 1888 - New species of fungi from various localities. Journal of Mycology 4, 97-107.

Ellis JB, Everhart BM. 1889 - New and rare species of North American fungi. Journal of Mycology 5, 145-157.

Eriksson OE. 2014 - Checklist of the non-lichenized ascomycetes of Sweden. Acta Universitatis Upsaliensis, Symbolae Botanicae Upsaliensis 36, 499.

Esfandiari E, Petrak F. 1950 - Pilze aus Iran. Sydowia 4, 11-38.

Esmaeilzadeh A, Zafari D, Bagherabadi S. 2020 - First report of Phyllosticta capitalensis causing leaf spots on ornamental Magnolia grandiflora and Syringa reticulate in Iran. New Disease Reports 41, 7.

Everett KR, Rees-George J. 2006 - Reclassification of an isolate of Guignardia citricarpa from New Zealand as Guignardia mangiferae by sequence analysis. Plant Pathology 55, 194-199.

Fan KC. 2002 - La mangrove de Taiwan. Bois et Forêts des Tropiques 273, 43-54.

FAO. 2007 - [Food and Agriculture Organization of the United Nations] The world's mangroves 1980-2005. FAO Forestry Paper 53. FAO, Rome, Italy.

http//www.fao.org/docrep/010/a1427e/a1427e00.htm.

Farr DF. 1991 - Septoria species on Cornus. Mycologia 83, 611-623.

Farr ML. 1973 - An annotated list of Spegazzini's fungus taxa, Vol. 1. Bibliotheca Mycologica 35, $1-823$. 
Feau N, Weiland JE, Stanosz GR, Bernier L. 2005 - Specific and sensitive PCR-based detection of Septoria musiva, S. populicola and S. populi, the causes of leaf spot and stem canker on poplars. Mycological Research 109, 1015-1028.

Fergus CL. 1954 - An epiphytotic of Phyllosticta leaf spot of maple. Plant Disease Reporter 38, 678-679.

Firman ID. 1972 - A list of fungi and plant parasitic bacteria, viruses and nematodes in Fiji. Phytopathological Paper 15, 1-36.

Foister CE. 1961 - The economic plant diseases of Scotland. Technology Bulletin Department of Agriculture and Fishery Scotland 1, 1-210.

Fox RTV. 2001 - Fungal foes in your garden. 51. Butt Rot. Mycologist 15, 184-185.

French AM. 1989 - California plant disease host index. California Department of Food and Agriculture, Sacramento, 394 pages.

French AM. 1987 - California plant disease host index. Part 1, Fruit and nuts. California Department of Food and Agriculture, Sacramento, 39 pages.

Gadgil PD. 2005 - Fungi on trees and shrubs in New Zealand. Fungi of New Zealand (Volume 4). Fungal Diversity Press, Hong Kong, 437 pages.

Gafforov YS. 2017 - A preliminary checklist of ascomycetous microfungi from southern Uzbekistan. Mycosphere 8, 660-696.

Garibaldi A, Bertetti D, Gullino ML. 2003 - First report of Septoria leaf spot on Cornus sericea in Italy. Plant Disease 87, 204.

Gasich EL, Titova YA, Berestetsky AO. 1999 - The herbaceous wild plants mycobiota of the Valaam Island. Mikologiya i Fitopatologiya 33, 392-401.

Ge X, Zhou R, Yuan Y, Xu H et al. 2016 - Identification and characterization of Paraphoma chrysanthemicola causing leaf spot disease on Atractylodes japonica in China. Journal of Phytopathology 164, 372-377.

Giatgong P. 1980 - Host index of plant diseases in Thailand. Second edition. Mycology Branch, Plant Pathology and Microbiology Division, Department of Agriculture and Cooperatives, Bangkok, Thailand. 118.

Gilman JC, Archer WA. 1929 - The fungi of Iowa parasitic on plants. Iowa State College Journal of Science 3, 299-507.

Ginns JH. 1986 - Compendium of plant disease and decay fungi in Canada 1960-1980. Canadian Government Publishing Centre 1813, 416.

Glienke C, Pereira OL, Stringari D, Fabris J et al. 2011 - Endophytic and pathogenic Phyllosticta species, with reference to those associated with Citrus black spot. Persoonia 26, 47-56.

Glienke-Blanco C, Aguilar-Vildoso CI, Vieira MLC, Barroso PAV, Azevedo JL. 2002 - Genetic variability in the endophytic fungus Guignardia citricarpa isolated from Citrus plants. Genetic and Molecular Biology 25, 251-255.

Gonzalez Fragoso R. 1917 - Introduccion al Estudio de la Florula de micromicetos de Cataluna. Junta de Ciències Naturals de Barcelona, Série Botánica, 187 pages.

Gonzalez MS, Rondon A. 2005 - First report of Guignardia psidii, an ascigerous state of Phyllosticta psidiicola, causing fruit rot on guava in Venezuela. Plant Disease 89, 773.

Goos RD. 2010 - The mycota of Rhode Island, a checklist of the fungi recorded in Rhode Island (including lichens and myxomycetes) Vol. 4. Rhode Island Natural History Survey, 222 pages.

Goos RD, Gowing DP. 1992 - Type specimens of fungi maintained at herbarium pacificum, Bernice P. Bishop Museum, Honolulu. Mycotaxon 43, 177-198.

Gorter GJMA. 1977 - Index of plant pathogens and the diseases they cause in cultivated plants in South Africa. Republic of South Africa, Dept. of Agricultural Technical Services 392, 1-177.

Grand LF. 1985 - North Carolina plant disease index. North Carolina Agricultural Research Service: Technology Bulletin 240, 1-157.

Grand LF, Menge JA, Bond JJ. 1975 - Partial checklist of fungi from highlands, North Carolina and vicinity. Journal of the Elisha Mitchell Scientific Society 91, 221-229. 
Greene HC. 1942 - Notes on Wisconsin parasitic fungi. II. Transactions of the Wisconsin Academy of Sciences 34, 83-98.

Greene HC. 1949 - Notes on Wisconsin parasitic fungi. XIII. The American Midland Naturalist Journal 41, 740-758.

Greene HC. 1962 - Notes on Wisconsin parasitic fungi. XXVIII. Transactions of the Wisconsin Academy of Sciences 51, 57-78.

Greene HC. 1958 - Notes on Wisconsin parasitic fungi. XXIV. Transactions of the Wisconsin Academy of Sciences 47, 99-117.

Greene HC. 1966 - Notes on Wisconsin parasitic fungi. XXXII. Transactions of the Wisconsin Academy of Sciences 55, 147-166.

Greuter W, Poelt J, Raimondo FM. 1991 - A checklist of Sicillian fungi. Bocconea 2, 222.

Guarnaccia V, Gehrmann T, Silva-Junior GJ, Fourie PH et al. 2019 - Phyllosticta citricarpa and sister species of global importance to Citrus. Molecular Plant Pathology 20, 1619-1635.

Guarnaccia V, Groenewald JZ, Li H, Glienke C et al. 2017 - First report of Phyllosticta citricarpa and description of two new species, $P$. paracapitalensis and $P$. paracitricarpa, from citrus in Europe. Studies in Mycology 87, 161-185.

Guo YL. 1997 - Fungal flora of the Daba Mountains, Imperfect fungi. Mycotaxon 61, 13-33.

Hall TA. 1999 - BioEdit, a user-friendly biological sequence alignment editor and analysis program for Windows 95/98/NT. Nucleic Acids Symposium Series 41, 95-98.

Hennings P. 1908 - Fungi S. paulenses IV a cl. Puttmans collecti. Hedwigia 48, 13.

Hennings P. 1905 - Fungi japonici VI. Botanische Jahrbücher für Systematik Pflanzengeschichte und Pflanzengeographie 37, 156-166.

Hernandez-Restrepo M, Schumacher RK, Wingfield MJ, Ahmad I et al. 2016 - Fungal systematics and evolution, FUSE 2. Sydowia 68, 193-230.

Hongsanan S, Hyde KD, Phookamsak R, Wanasinghe DN et al. 2020 - Refined families of Dothideomycetes. Mycosphere 11, 1553-2107.

Hsueh ML. 1995 - Decreasing wetland forest, about Taiwan mangroves. Taiwan Endemic Species Research Institute, Taiwan, 116 p. (in Chinese).

Huguenin B. 1966 - Micromycetes de Nouvelle-Caledonie. Cahiers ORSTOM, Série Biologie 1: $61-91$.

Huseyinov E, Selcuk F. 2001 - Contribution to study of mycoflora of Turkey I. Coelomycetes of orders Melanconiales and Sphaeropsidales on forest trees and shrubs in the Black Sea coast (Rize and Trabzon Provinces). Mikologiia i Fitopatologiia 35, 28-33.

Hyde KD, Alcorn JL. 1993 - Some disease-associated microorganisms on plants of Cape York Peninsula and Torres Strait Islands. Australasian Plant Pathology 22, 73-83.

Hyde KD, Cannon PF. 1992 - Polystigma sonneratiae causing leaf spots on the mangrove genus Sonneratia. Australian Systematic Botany 5, 415-420.

Hyde KD, de Silva NI, Jeewon R, Bhat DJ et al. 2020a - AJOM new records and collections of fungi, 1-100. Asian Journal of Mycology 3, 22-294.

Hyde KD, Jeewon R, Chen YJ, Bhunjun C et al. 2020b - The numbers of fungi, is the descriptive curve flattening? Funga Diversity 103, 219-271.

Hyde KD, Jones EBG. 1988 - Marine mangrove fungi. Marine Ecology 9, 15-33.

Hyde KD, Jones EBG, Leaño E, Pointing SB et al. 1998 - Role of fungi in marine ecosystems. Biodiversity \& Conservation 7, 1147-1161.

Hyde KD, Lee SY. 1998 - Ecology of mangrove fungi and their role in nutrient cycling, What gaps occur in our knowledge?. Hydrobiologia 295, 107-118.

Hyde KD, Nilsson RH, Alias SA, Ariyawansa HA et al. 2014 - One stop shop, backbones trees for important phytopathogenic genera, I (2014). Fungal Diversity 67, 21-125.

Hyde KD, Norphanphoun C, Chen J, Dissanayake AJ et al. 2018 - Thailand's amazing diversity, up to $96 \%$ of fungi in northern Thailand may be novel. Fungal Diversity 93, 215-239.

Ismail AM, Cirvilleri G, Lombard L, Crous PW et al. 2013 - Characterisation of Neofusicoccum species causing mango dieback in Italy. Journal of Plant Pathology 95, 549-557. 
Ismail AM, Cirvilleri G, Polizzi G, Crous PW et al. 2012 - Lasiodiplodia species associated with dieback disease of mango (Mangifera indica) in Egypt. Australasian Plant Pathology 41, 649-660.

Jaczewski AA. 1915 - Materials for mycology and phytopathology in Russia (Vol. 1) (Translated from Russian). Bureau of Mycology and Phytopathology, Petrograd, 79 pages.

Jayasiri SC, Hyde KD, Ariyawansa HA, Bhat JD et al. 2015 - The faces of fungi database, fungal names linked with morphology, phylogeny and human impacts. Fungal Diversity 74, 3-18.

Jayawardena RS, Hyde K, Damm U, Cai L et al. 2016 - Notes on currently accepted species of Colletotrichum. Mycosphere 7, 1192-1260.

Jin J. 2011 - Conidial morphology changes in four Phyllosticta species. Mycotaxon 115, 401-406.

Johnston A. 1960 - A preliminary plant disease survey in Sarawak. Plant Protection Division, FAO, Rome, Italy.

Jorstad I. 1960 - Iranian plants collected by Per Wendelbo in 1959. II. Uredinales and some other parasitic fungi. Årbok for Universitetet i Bergen. Matematisk-naturvitenskapelig Serie 11, 133.

Jorstad I. 1962 - Investigations on the Uredinales and other parasitic fungi in Mallorca and Menorca. Skrifter utgitt av Det Norske Videnskaps-Akademi i Oslo. MatematiskNaturvidenskapelig Klasse 2, 1-73.

Kamal. 2010 - Cercosporoid fungi of India. Bishen Singh Mahendra Pal Singh, Dehra Dun, India, 351 pages.

Katoh K, Standley DM. 2013 - MAFFT multiple sequence alignment software version 7, improvements in performance and usability. Molecular Biology and Evolution 30, 772-80.

Kinge TR, Mih AM. 2011 - Ganoderma ryvardense sp. nov. associated with basal stem rot (BSR) disease of oil palm in Cameroon. Mycosphere 2, 179-188.

Kirschner R. 2018 - Phyllosticta capitalensis sporulating on ginkgo leaves in Taiwan. Plant Pathology \& Quarantine 8, 10-13.

Kobayashi T 2007 - Index of fungi inhabiting woody plants in Japan. Host, distribution and literature. Zenkoku-Noson-Kyoiku Kyokai Publishing Co., Ltd., 1227 pages.

Kobayashi T, Sasaki K. 1975 - Notes on new or little-known fungi inhabiting woody plants in Japan VII. Transactions of the Mycological Society of Japan 16, 230-244.

Kumar S, Stecher G, Li M, Knyaz C, Tamura K. 2018 - MEGA X, molecular evolutionary genetics Analysis across computing platforms. Molecular Biology and Evolution 35, 15471549.

Kumar V, Cheewangkoon R, Gentekaki E, Maharachchikumbura S et al. 2019 - Neopestalotiopsis alpapicalis sp. nov. a new endophyte from tropical mangrove trees in Krabi Province (Thailand). Phytotaxa 393, 251-262.

Kwon JH, Choi O, Kang DW, Kim WI, Kim J. 2015 - The occurence of leaf blight on Ophiopogon japonicas caused by Phyllosticta ophiopogonis in Korea. Australasian Plant Disease Notes 10, 22.

Lambe RC. 1960 - Diseases of cut greenery in Oregon. Plant Disease Reporter 44, 718-720.

Lenne JM. 1990 - World list of fungal diseases of tropical pasture species. Phytopathological Paper 31, 1-162.

Leuchtmann A, Petrini O, Petrini LE, Carroll GC. 1992 - Isozyme polymorphism in six endophytic Phyllosticta species. Mycological Research 96, 287-294.

Lin S, Sun X, He W, Zhang Y. 2017 - Two new endophytic species of Phyllosticta (Phyllostictaceae, Botryosphaeriales) from Southern China. Mycosphere 8, 1273-1288

Lind J. 1913 - Danish fungi. Copenhagen. Unknown journal or publisher, 648 pages.

Lisboa DO, Silva MA, Machado AR, Pinho DB et al. 2016 - First report of botryosphaeriaceous fungi causing canker on Cedrela fissilis and leaf spots on Cariniana estrellensis in forest nursery in Brazil. Forest Pathology 46, 362-365.

Liu JK, Phookamsak R, Doilom M, Wikee S et al. 2012 - Toward a natural classification of Botryosphaeriales. Fungal Diversity 57, 149-210. 
Liu PSW. 1977 - A supplement to a host list of plant diseases in Sabah, Malaysia. Phytopathological Paper 21, 1-49.

Lotz-Winter H, Hofmann T, Kirschner R, Kursawe M et al. 2011 - Fungi in the botanical garden of the University of Frankfurt. Zeitschrift für Mykologie 77, 89-122.

Lou BG, Xu YD, Sun C, Lou XM. 2009 - First report of leaf blight on duying caused by Phyllosticta anacardiacearum in China. Plant Disease 93, 546.

Lu B, Hyde KD, Ho WH, Tsui KM et al. 2000 - Checklist of Hong Kong Fungi. Fungal Diversity Press, Hong Kong, 207 pages.

Luginbuehl M, Mueller E. 1980 - Studies on endophytic fungi. I. Infection patterns of endophytes on Hedera helix L. Berichte der Deutschen Botanischen Gesellschaft 90, 244-250.

Lynch SC, Eskalen A, Zambino PJ, Mayorquin JS, Wang DH. 2013 - Identification and pathogenicity of Botryosphaeriaceae species associated with coast live oak (Quercus agrifolia) decline in southern California. Mycologia 105, 125-140.

Maneval WE. 1937 - A list of the Missouri fungi. University of Missouri Studies 12.

Mankin CJ. 1969 - Fungous diseases on non-grass plants in South Dakota. Agricultural Experiment Station, South Dakota State University. Technology Bulletin 36, 1-28.

Marin-Felix Y, Hernandez-Restrepo M, Wingfield MJ, Akulov A et al. 2019 - Genera of phytopathogenic fungi: GOPHY 2. Study in Mycolology 92, 47-133.

Martin WH. 1931 - Miscellaneous diseases of Rhododendron. New Jersey Agricultural College Experiment Station. Nursery Disease Notes 4, 1-4.

Mathur RS. 1979 - The coelomycetes of India. Bishen Singh Mahendra Pal Singh, Delhi, India., 460 pages.

Mayorquin JS, Wang DH, Twizeyimana M, Eskalen A. 2016 - Identification, distribution, and pathogenicity of Diatrypaceae and Botryosphaeriaceae associated with citrus branch canker in the Southern California desert. Plant Disease 100, 2402-2413.

McDonald V, Eskalen A. 2011 - Botrysphaeriaceae species associated with avacado branch cankers in California. Plant Disease 95, 1465-1473.

McGuire Jr JU, Crandall BS. 1967 - Survey of insect pests and plant diseases of selected food crops of Mexico, Central America and Panama. International Agricultural Development Service, U.S. Department of Agriculture, 157 pages.

McKenzie EHC. 1996 - Fungi, bacteria and pathogenic algae on plants in American Samoa, Technical paper No. 206. South Pacific Commission Information Doc, 1-77 pages.

McManus PS. 1998 - First report of early rot of cranberry caused by Phyllosticta vaccinii in Wisconsin. Plant Disease 82, 350.

McMillan Jr RT. 1964 - Studies of a recently described Cercospora on Rhizophora mangle. Plant Disease Reporter 48, 909-911.

McMillan Jr RT. 1986 - Guignardia citricarpa a cause of black spot on mango foliage in Florida. Journal of Phytopathology 117, 260-264.

Mendes MAS, da Silva VL, Dianese JC, Ferreira MASV et al. 1998 - Fungos em plants no Brasil. Embrapa-SPI/Embrapa-Cenargen, Brasilia, 555 pages.

Meredith DS. 1969 - Fungal diseases of bananas in Hawaii. Plant Disease Reporter 53, 63-66.

Meyer L, Slippers B, Korsten L, Kotze JM, Wingfeld MJ. 2001 - Two distinct Guignardia species associated with citrus in South Africa. South African Journal of Science 97, 191-194.

Meyer L, Sanders GM, Jacobs R, Korsten L. 2006 - A one-day sensitive method to detect and distinguish between the citrus black spot pathogen Guignardia citricarpa and the endophyte Guignardia mangiferae. Plant Disease 90, 97-101.

Miles AK, Tan YP, Tan MK, Drenth A et al. 2013 - Phyllosticta spp. on cultivated citrus in Australia. Australasian Plant Pathology 42, 461-467.

Miller JH, Campbell WA, Thompson GE. 1954 - Diseases and insects affecting the commonly planted trees and shrubs in Georgia. Plant Disease Reporter 38, 362-369.

Miller JW. 1990 - Bureau of plant pathology. Tri-ology Technical Report. Division of Plant Industry, Florida 29, 1. 
Miller JW. 1991 - Bureau of plant pathology. Tri-ology Technical Report. Division of Plant Industry, Florida 30, 1-3.

Miller JW. 1997 - Plant pathology. Tri-ology Technical Report. Division of Plant Industry, Florida 36, 14-16.

Miller MA, Pfeiffer W, Schwartz T. 2010 - Creating the CIPRES Science Gateway for inference of large phylogenetic trees. In, Proceedings of the Gateway Computing Environments Workshop (GCE), 14 Nov. 2010, New Orleans, LA, pp. 1-8.

Minnis AM, Kennedy AH, Grenier DB, Palm ME, Rossman AY. 2012 - Phylogeny and taxonomic revision of the. Planistromellaceae. including its coelomycetous anamorphs, contributions towards a monograph of the genus. Kellermania. Persoonia 29, 11-28.

Minter DW, Rodriguez Hernandez M, Mena Portales J. 2001 - Fungi of the Caribbean, an annotated checklist. PDMS Publishing, 946 pages.

Mix AJ. 1954 - Report of the 1952 foray. Mycologia 46, 112-123.

Motohashi K, Araki I, Nakashima C. 2008 - Four new species of Phyllosticta, one new species of Pseudocercospora, and one new combination in Passalora from Japan. Mycoscience 49, 138-146.

Motohashi K, Inaba S, Anzai K, Takamatsu S, Nakashima C. 2009 - Phylogenetic analyses of Japanese species of Phyllosticta sensu stricto. Mycoscience 50, 291-302.

Mulenko W, Majewski T, Ruszkiewicz-Michalska M. 2008 - A preliminary checklist of micromycetes in Poland. W. Szafer Institute of Botany, Polish Academy of Sciences 9, 752.

Murali TS, Suryanarayanan TS, Venkatesan G. 2007 - Fungal endophyte communities in two tropical forests of southern India, diversity and host affiliation. Mycological Progress 6, 191199.

Myllys L, Stenroos S, Thell A. 2002 - New genes for phylogenetic studies of lichenized fungi, glyceraldehyde-3-phosphate dehydrogenase and beta-tubulin genes. Lichenologist 34, 237246.

Nag Raj TR. 1993 - Coelomycetous anamorphs with appendage-bearing conidia. Mycologue Publications, Waterloo, Ontario, 1-1101 pages.

Nasehi A, Sathyapriya H, Wong MY. 2020 - First report of leaf spot on oil palm caused by Phyllosticta capitalensis in Malaysia. Plant Disease 104, 288.

Neely D. 1959 - New and unusual leaf disease fungi for Illinois. Plant Disease Reporter 43, 498499.

Nogueira Junior AF, Fischer IH, Braganca CAD, Massola Jr NS, Amorim L. 2016 - Identification of Botryosphaeriaceae species that cause stylar-end rot of guavas and characterisation of the disease monocycle. European Journal of Plant Pathology 144, 271-287.

Norphanphoun C, Doilom M, Daranagama DA, Phookamsak R et al. 2017 - Revisiting the genus Cytospora and allied species. Mycosphere 8, 51-97.

Norphanphoun C, Jayawardena RS, Chen Y, Wen TC et al. 2019 - Morphological and phylogenetic characterization of novel pestalotioid species associated with mangroves in Thailand. Mycosphere 10, 531-578.

Norphanphoun C, Raspé O, Jeewon R, Wen TC, Hyde KD. 2018 - Morphological and phylogenetic characterisation of novel Cytospora species associated with mangroves. MycoKeys 38, 93-120.

Norphanphoun C, Hongsanan S, Bhat JD, Kuo CH, Hyde KD 2020 - A new species of Alternaria associated with leaf blight of Ficus and leaf spot of Kandelia candel in Taiwan. Mycoscience (in prep).

Nouri MT, Lawrence DP, Yaghmour MA, Michailides TJ, Trouillas FP. 2018 - Neoscytalidium dimidiatum causing canker, shoot blight and fruit rot of almond in California. Plant Disease 102, 1638-1647.

Nylander JAA. 2004 - MrModeltest 2.3. Evolutionary Biology Centre, Uppsala University. https,//github.com/nylander/MrModeltest2. 
O’Donnell K, Rooney AP, Proctor RH, Brown DW et al. 2013 - Phylogenetic analyses of rpb1 and $r p b 2$ support a middle Cretaceous origin for a clade comprising all agriculturally and medically important fusaria. Fungal Genetics and Biology 52, 20-31.

O’Donnell K, Ward TJ, Robert VARG, Crous PW et al. 2015 - DNA sequence-based identification of Fusarium: current status and future directions. Phytoparasitica 43, 583-595.

Okane I, Lumyong S, Ito T, Nakagiri A. 2003 - Extensive host range of an endophytic fungus, Guignardia endophyllicola (anamorph, Phyllosticta capitalensis). Mycoscience 44, 353-363.

Olatinwo RO, Hanson EJ, Schilder AM. 2003 - A first assessment of the cranberry fruit rot complex in Michigan. Plant Disease 87, 550-556.

Overholts LO. 1938 - Notes on fungi from the lower Mississippi Valley. Bulletin Torrey Botanical Club 65, 167-180.

Palomares-Rius JE, Hirooka Y, Tsai IJ, Masuya H et al. 2014 - Distribution and evolution of glycoside hydrolase family 45 cellulases in nematodes and fungi. BMC Evolutionary Biology $14,69$.

Pande A. 2008 - Ascomycetes of Peninsular India. Scientific Publishers (India), Jodhpur, 584.

Pang KL, Jheng JS, Jones EBG. 2011 - Marine mangrove fungi of Taiwan. National Taiwan Ocean University Press. Keelung, Taiwan.

Pantidou ME. 1973 - Fungus-host index for Greece. Benaki Phytopathology Inst., Kiphissia, Athens., 382 pages.

Parmelee JA. 1988 - Parasitic fungi of Newfoundland based on specimens from Gros Morne National Park. Canadian Field-Naturalist 102, 442-464.

Parmelee JA. 1958 - Some foliicolous fungi of the Pyrolaceae. Canadian Journal of Botany 38, 865-881.

Parris GK. 1959 - A revised host index of Mississippi plant diseases. Mississippi State University, Botany Department, 146 pages.

Paul AR, Blackburn MD. 1986 - Phyllosticta beaumarisii sp. nov., a cause of leafspot on Muehlenbeckia adpressa. Australasian Plant Pathology 15, 40-41.

Pennycook SR. 1989 - Plant diseases recorded in New Zealand. 3 Vol. Plant Disease Div., D.S.I.R., Auckland, - pages.

Peregrine WTH, Ahmad KB. 1982 - Brunei, A first annotated list of plant diseases and associated organisms. Phytopathological Paper 27, 1-87.

Peres NA, Harakava R, Carroll GC, Adaskaveg JE, Timmer LW. 2007 - Comparison of molecular procedures for detection and identification of Guignardia citricarpa and G. mangiferae. Plant Disease 91, 525-531.

Persoon CH. 1818 - Traité sur les champignons comestibles, contenant l'indication des espèces nuisibles; précédé d'une introduction a l'histoire des champignons, avec quatre planches coloriées. Paris, Belin-Leprieur.

Petrak F. 1963 - Sydowia 16, 155-198

Petrak F. 1934 - Mykologische beitrage zur flora von sibirien II. Hedwigia 74, 30-78.

Petrak F. 1953 - Ein beitrag zur pilzflora Florida. Sydowia 7, 103-116.

Petrak F, Sydow H. 1931 - Mycromycetes philippinenses. Series secunda. Annales Mycologici 29, 145-279.

Petrini LE, Petrini O, Leuchtmann A, Carroll GC. 1991 - Conifer inhabiting species of Phyllosticta. Sydowia 43, 148-169.

Phillips A, Alves A, Correia A, Luque J. 2005 - Two new species of Botryosphaeria with brown, 1-septate ascospores and Dothiorella anamorphs. Mycologia 97, 513-529.

Phillips AJL, Alves A. 2009 - Taxonomy, phylogeny, and epitypification of Melanops tulasnei, the type species of Melanops. Fungal Diversity 38, 155-166.

Photita W, Lumyong S, Lumyong P, Hyde KD, McKenzie EHC. 2002 - Index of fungi described from the Musaceae. Mycotaxon 81, 491-503.

Piepenbring M. 2006 - Checklist of fungi in Panama. Preliminary version. Puente Biologica 1, 1190. 
Pirone PP. 1939 - Diseases of ornamental plants. New Jersey Agricultural College Experiment Station: Circular 385, 1-80.

Pirozynski KA. 1974 - Botryosphaeria rhodorae. Fungi Canadenses 21, 1-2.

Polashock JJ, Caruso FL, Oudemans PV, McManus PS, Crouch JA. 2009 - The North American cranberry fruit rot fungal community, a systematic overview using morphological and phylogenetic affinities. Plant Pathology 58, 1116-1127.

Preston DA. 1945 - Host index of Oklahoma plant diseases. Oklahoma Agricultural Experiment Station: Technology Bulletin T-21, 1-168.

Preston DA. 1947 - Host index of Oklahoma plant diseases, supplement, 1947. Oklahoma Agricultural Experiment Station: Technology Bulletin T-21, 1-39.

Raabe RD, Conners IL, Martinez AP. 1981 - Checklist of plant diseases in Hawaii. College of Tropical Agriculture and Human Resources, University of Hawaii. Information Text Series No. 22. Hawaii Institute of Tropical Agriculture and Human Resources, 313 pages.

Rambaut A. 2014 - FigTree v1.4, tree figure drawing tool. http,//treebio.ed.ac.uk/software/figtree/.

Rampadarath S, Puchooa D, Jeewon R, Bandhoa K. 2018 - Diversity, seasonal variation and antibacterial activity of endophytic fungi associated with the genus Jatropha in Mauritius. Journal of Biotechnology and Biomaterials 8, 1.

Rao VG, Mani Varghese KI. 1988 - Forest micro-fungi. V. Some new records of ascomycetes from India. International Journal of Mycology and Lichenology 3, 287-293.

Rashmi M, Kushveer JS, Sarma VV. 2019 - A worldwide list of endophytic fungi with notes on ecology and diversity. Mycosphere 10, 798-1079.

Reeder R, Kelly PL, Harling R. 2008 - First confirmed report of citrus black spot caused by Guignardia citricarpa on sweet oranges (Citrus sinensis) in Uganda. New Disease Reports 17, 33.

Reinking OA. 1918 - Philippine economic plant diseases. Philippine Journal of Science 13, 165274.

Reinking OA. 1919 - Host index of diseases of economic plants in the Philippines. Philippine Agricultural Scientist 8, 38-54.

Reinking OA. 1921 - Citrus diseases of the Philippines, southern China, Indo-China and Siam. Philippine Agricultural Scientist 9, 121-179.

Rodrigues KF, Sieber TN, Grunig CR, Holdenrieder O. 2004 - Characterization of Guignardia mangiferae isolated from tropical plants based on morphology, ISSC-PCR amplifications and ITS1-5.8S-ITS2 sequences. Mycological Research 108, 45-52.

Rogerson CT. 1953 - Kansas mycological notes, 1951. Transactions of the Kansas Academy of Science 56, 53-57.

Rokas A, Carroll SB. 2005 - More genes or more taxa? The relative contribution of gene number and taxon number to phylogenetic accuracy. Molecular Biology and Evolution 22, 13371344.

Ronquist F, Teslenko M, van der Mark P, Ayres DL et al. 2012 - MrBayes 3.2, efficient Bayesian phylogenetic inference and model choice across a large model space. Systematic Biology 61, 539-542.

Rossman AY. 2009 - The impact of invasive fungi on agricultural ecosystems in the United States. Biological Invasions 11, 97-107.

Roy AJ. 1967 - Some fungi from Almora. Indian Phytopathology 20, 340-348.

Ruszkiewicz-Michalska M, Tkaczuk C, Dynowska M, Sucharzewska E et al. 2012 - Preliminary studies of fungi in the Biebrza National Park (NE Poland). I. Micromycetes. Acta Mycologica 47, 213-234.

Ryvarden L. 2000 - Studies in neotropical Polypores 2, a preliminary key to neotropical species of Ganoderma with a laccate pileus. Mycologia 92, 180-191.

Saenger P. 2002 - Mangrove ecology, silviculture and conservation. Dordrecht, Kluwer Academic Publishers, $372 \mathrm{p}$. 
Sakayaroj J, Pang KL, Jones EBG. 2012 - Multigene phylogeny of the Halosphaeriaceae, Its ordinal status, relationships between genera and morphological character evolution. Fungal Diversity 46, 87-109.

Sampson PJ, Walker J. 1982 - An annotated list of plant diseases in Tasmania. Department of Agriculture Tasmania, 121 pages.

Sánchez R, Serra F, Tarraga J, Medina I et al. 2011 - Phylemon 2.0, a suite of web-tools for molecular evolution, phylogenetics, phylogenomics and hypotheses testing. Nucleic Acids Research 39, W470-474.

Sarbhoy AK, Lal G, Varshney JL. 1971 - Fungi of India (1967-71). Navyug Traders, New Delhi, 148 pages.

Schubert TS. 1991 - Bureau of plant pathology. Tri-ology Technical Report. Division of Plant Industry, Florida 30, 5-6.

Schubert TS, Peres NA, Palm ME, Jeyaprakash A et al. 2012 - First report of Guignardia citricarpa associated with citrus black spot on sweet orange (Citrus sinensis) in North America. Plant Disease 96, 1225.

Seaver FJ. 1922 - Phyllostictales, Phyllostictaceae (Pars). North American Flora 6, 1-84.

Shaw BD, Carroll, GC, Hoch HC. 2006 - Generality of the prerequisite of conidium attachment to a hydrophobic substratum as a signal for germination among Phyllosticta species. Mycologia 98, 186-194.

Shaw CG 1973 - Host fungus index for the Pacific Northwest - I. Hosts. Washington State University Agricultural Experiment Station Bulletin 765, 1-121.

Shaw DE. 1984 - Microorganisms in Papua New Guinea. Department of Primary Industries, Research Bulletin 33, 1-344.

Shivas RG. 1989 - Fungal and bacterial diseases of plants in Western Australia. Journal of the Royal Society of Western Australia 72, 1-62.

Shivas RG, Young AJ, Crous PW. 2009 - Pseudocercospora avicenniae. Fungal Planet 40. Persoonia 23, 192-193.

Silva M, Pereira OL. 2007 - First report of Guignardia endophyllicola leaf blight on Cymbidium (Orchidaceae) in Brazil. Australasian Plant Disease Notes 2, 31-32.

Silva M, Pereira OL, Braga IF, Leli SM. 2008 - Leaf and pseudobulb diseases on Bifrenaria harrisoniae (Orchidaceae) caused by Phyllosticta capitalensis in Brazil. Australasian Plant Disease Notes 3, 53-56.

Simmonds JH. 1966 - Host index of plant diseases in Queensland. Queensland Department of Primary Industries, Brisbane, 111.

Simon UK, Groenewald JZ, Crous PW. 2009 - Cymadothea trifolii, an obligate biotrophic leaf parasite of Trifolium, belongs to Mycosphaerellaceae as shown by nuclear ribosomal DNA analyses. Persoonia 22, 49-55.

Simonyan SA. 1981 - Mycoflora of Botanical gardens and arboretums of the Armenian S.S.R. (Translated from Russian). Hayka Armenian SSR USSR, 234 pages.

Sivanesan A. 1984 - The bitunicate ascomycetes and their anamorphs. J. Cramer, Vaduz, 701 pages.

Sivanesan A, Hsieh WH. 1989 - New species and new records of ascomycetes from Taiwan. Mycological Research 93, 340-351.

Slippers B, Crous PW, Denman S, Coutinho TA et al. 2004 - Combined multiple gene genealogies and phenotypic characters differentiate several species previously identified as Botryosphaeria dothidea. Mycologia 96, 83-101.

Spaulding P. 1961 - Foreign diseases of forest trees of the world. USDA Agriculture handbook 197, 1-361.

Stevens FL. 1920 - New or noteworthy Puerto Rican fungi. Botanical Gazette 70, 399-402.

Stevens FL. 1925 - Hawaiian fungi. Bulletin of the Bernice P. Bishop Museum 19, 1-189.

Stevenson JA. 1975 - Fungi of Puerto Rico and the American Virgin Islands. Contribution of Reed Herbarium 23, 743. 
Su YY, Cai L. 2012 - Polyphasic charcterization of three new Phyllosticta spp. Persoonia 28, 7684.

Sultan A, Johnston PR, Park D, Robertson AW. 2011 - Two new pathogenic ascomycetes in Guignardia and Rosenscheldiella on New Zealand's pygmy mistletoes (Korthalsella, Viscaceae). Study in Mycology 68, 237-247.

Sun J, Wang DM, Huang XY, Liu ZH. 2013 - First report of a leaf spot on Hazel leaves caused by Phyllosticta coryli in Liaoning Province of China. Plant Disease 97, 1254.

Sun JM, Zhang Y, Zhang JZ, Lan X, Lu J. 2016 - First report of freckle disease of banana caused by Phyllosticta capitalensis in Guangxi, Southwest China. Journal of Plant Pathology 98, 175.

Sun X, Guo, L-D, Hyde KD. 2011 - Community composition of endophytic fungi in Acer truncatum and their role in decomposition. Fungal Diversity 47, 85-95.

Swart L, Crous PW, Denman S, Palm ME. 1998 - Fungi occurring on Proteaceae. I. South African Journal of Botany 64, 137-146.

Swofford DL. 2002 - PAUP, phylogenetic analysis using parsimony, version 4.0 b10. Sinauer Associates, Sunderland.

Tai FL. 1979 - Sylloge fungorum sinicorum. Science Press, Academica Sinica, Peking, 1527 pages.

Takeda I, Guerrero R, Bettucci L. 2003 - Endophytic fungi of twigs and leaves from Ilex paraguariensis in Brazil. Sydowia 55, 372-380.

Tang JR, Li YL, Yin XG, Lu JN, Zhou YH. 2020 - First report of castor dark leaf spot caused by Phyllosticta capitalensis in Zhanjiang, China. Plant Disease 104, 1856.

Tassi F. 1902 - I generi Phyllosticta Pers., Phoma Fr., Macrophoma (Sacc.) Berl. et Vogl. e i loro generi analoghi, giusta la legge d'analogia. Universita Di Siena Istituto Botanico 5, 133-672.

Teng SC. 1996 - Fungi of China. Mycotaxon, Ltd., Ithaca, NY, 586 pages.

Tengwall TA. 1924 - Ueber einige parasitische pilze auf kultivierten Rhododendren. Meded. Phytopathology Lab. Willie Commelin Scholten 6, 58-61.

Teodoro NG. 1937 - An enumeration of Philippine fungi. Technical bulletin Philippines Department of Agriculture and Commerce 4, 1-585.

Than PP, Jeewon R, Hyde KD, Pongsupasamit S et al. 2008 - Characterisation and pathogenicity of Colletotrichum species asscoaited with anthracnose on Chili (Capsicum spp.) in Thailand. Plant Pathology 57, 562-572.

Thatoi H, Behera BC, Mishra RR. 2013 - Ecological role and biotechnological potential of mangrove fungi, a review. Mycology 4, 54-71.

Thatoi HN, Behera BC, Danger TK, Mishra RR. 2012 - Microbial biodiversity in mangrove soil of Bhitarkanika, Odisha, India. International Journal of Environmental Biology 2, 50-58.

Thaung MM. 2008a - Biodiversity survey of coelomycetes in Burma. Australasian Mycologist 27, 74-110.

Thaung MM. 2008b - Pathologic and taxonomic analysis of leaf spot and tar spot diseases in a tropical dry to wet monsoon ecosystem of lowland Burma. Australasian Plant Pathology 37, 180-197.

Timmwemans A. 1957 - A attack of Rhododendron-leaves by Chaetapiospora rhododendri (Tengw.) v. Arx. (In Dutch.) Tijdschr Over Planteziekten 63, 191-192.

Tracy SM, Earle FS. 1895 - New species of parasitic fungi. Bulletin of the Torrey Botanical Club 22, 174-179.

Trakunyingcharoen T, Lombard L, Groenewald JZ, Cheewangkoon R et al. 2015 - Caulicolous Botryosphaeriales from Thailand. Persoonia 34, 87-99.

Tran NT, Miles AK, Dietzgen RG, Drenth A. 2019 - Phyllosticta capitalensis and P. paracapitalensis are endophytic fungi that show potential to inhibit pathogenic P. citricarpa on citrus. Australasian Plant Pathology 48, 281-296.

Treigiene A. 2006 - Species of Phyllosticta and their teleomorphs from Lithuania. Mikologiya i Fitopatologiya 40, 426-432. 
Turner PD. 1971 - Microorganisms associated with oil palm (Elaeis guineensis Jacq.). Phytopathological Paper 14, 1-58.

Unamuno PLM. 1941 - Enumeracion y distribucion geografica de los ascomicetos de la Peninsula Iberica y de las Islas Baleares. Memorias Real Academia de Ciencias Exactas Madrid 8, 1403.

Urtiaga R. 1986 - Indice de enfermedades en plantas de Venezuela y Cuba. Impresos en Impresos Nuevo Siglo. S.R.L., Barquisimeto, Venezuela, 202 pages.

Urtiaga R. 2004 - Indice de enfermedades en plantas de Venezuela y Cuba, Second edition. Unknown journal or publisher, 301.

van der Aa HA. 1973 - Studies in Phyllosticta. I. Study in Mycology 5, 1-110.

van der Aa HA, Vanev S. 2002 - A revision of the species described in Phyllosticta. Utrecht, Centraalbureau voor Schimmelcultures.

Vanev SG, Sameva EF, Bakalova GG. 1997 - Order Sphaeropsidales. Fungi Bulgaricae 3, 1-335.

Vanev SG, van der Aa HA. 1998 - An annotated list of the published names in Asteromella. Persoonia 17, 47-67.

Verkley GJM, Quaedvlieg W, Shin HD, Crous PW. 2013 - A new approach to species delimitation in Septoria. Study in Mycology 75, 213-305.

Viala P, Ravaz L. 1892 - Sur la dénomination botanique (Guignardia bidwellii) du black-rot. Bulletin de la Société Mycologique de France 8, 63.

Vollbrecht G, Johansson U, Eriksson H, Stenlid J. 1995 - Butt rot incidence, yield and growth pattern in a tree species experiment in southwestern Sweden. Forest Ecological Management 76, 87-93.

von Arx JA, Mueller E. 1954 - Die Gattungen der amerosporen Pyrenomyceten. Beiträge zur Kryptogamenflora der Schweiz 11, 1-434.

von Hoehnel F. 1931 - Mykologische Beitrage Mitt. Mitteilung Botanical Laboratory 8, 33-40.

Vu D, Groenewald M, de Vries M, Gehrmann T et al. 2019 - Large-scale generation and analysis of filamentous fungal DNA barcodes boosts coverage for kingdom fungi and reveals thresholds for fungal species and higher taxon delimitation. Study in Mycology 92, 135-154.

Waller TJ, Gager J, Constantelos C, Oudemans PV. 2020 - The role of flowers in the disease cycle of Colletotrichum fioriniae and other cranberry fruit rot fungi. Phytopathology 110, 1270 1279.

Wang XH, Chen G, Huang F, Zhang J et al. 2012 - Phyllosticta species associated with citrus diseases in China. Fungal Diversity. 52, 209-224

Watson AJ. 1971 - Foreign bacterial and fungus diseases of food, forage, and fiber crops. U.S.D.A. Agricultural Research Service, 111.

Weidemann GJ, Boone DM. 1983 - Incidence and pathogenicity of Phyllosticta vaccinii and Botryosphaeria vaccinii on cranberry. Plant Disease 67, 1090-1093.

Weidemann GJ, Boone DM, Burdsall Jr HH. 1982 - Taxonomy of Phyllosticta vaccinii (Coelomycetes) and a new name for the true anamorph of Botryosphaeria vaccinii (Dothideales, Dothioraceae). Mycologia 74, 59-65.

White RP. 1933 - The insects and diseases of Rhododendron and Azalea. Journal of Economic Entomology 26, 631-640.

White RP, Hamilton CC. 1935 - Diseases and insect pests of Rhododendron and Azalea. New Jersey Agricultural Experiment Station; Circular 350, 1-22.

White TJ, Bruns TD, Lee S, Taylor J. 1990 - Amplification and direct sequencing of fungal ribosomal RNA genes for phylogenetics. In, Innis MA, Gelfand DH, Sninsky JJ, White TJ (eds) PCR protocols, a guide to methods and applications. Academic, San Diego, 315-322 pages.

Whiteside JO. 1966 - A revised list of plant diseases in Rhodesia. Kirkia 5, 87-196.

Wiehe PO. 1953 - The plant diseases of Nyasaland. Mycological Paper 53, 1-39.

Wijayawardene NN, Hyde KD, Al-Ani LKT, Tedersoo L et al. 2020 - Outline of fungi and funguslike taxa. Mycosphere 11, 1060-1456. 
Wikee S, Lombard L, Crous PW, Nakashima C et al. 2013a - Phyllosticta capitalensis, a widespread endophyte of plants. Fungal Diversity 60, 91-105.

Wikee S, Lombard L, Nakashima C, Motohashi K et al. 2013b - A phylogenetic re-evaluation of Phyllosticta (Botryosphaeriales). Study in Mycology 76, 1-29.

Wikee S, Udayanga D, Crous PW, Chukeatirote E et al. 2011 - Phyllosticta an over-view of current status of species recognition. Fungal Diversity 51, 43-61.

Wikee S, Wulandari NF, McKenzie EHC, Hyde KD. 2012 - Phyllosticta ophiopogonis sp. nov. from Ophiopogon japonicas (Liliaceae). Saudi Journal of Biological Sciences 19, 13-16.

Williams L, Hayne SC. 1982 - Index of plant diseases in West Virginia. West Virginia Department of Agriculture, Plant Pest Control Division, 115 pages.

Williams TH, Liu PSW. 1976 - A host list of plant diseases in Sabah, Malaysia. Phytopathological Paper 19, 1-67.

Winter G. 1885 - Exotische Pilze II. Hedwigia 24, 21-35.

Wolf FA, Garren KH, Miller JK. 1938 - Fungi of the Duke Forest and their relation to forest pathology. Bulletin of Duke University, the School of Forestry 2, 1-122.

Wong MH, Crous PW, Henderson J, Groenewald JZ, Drenth A. 2012 - Phyllosticta species associated witih freckle disease of banana. Fungal Diversity 56, 173-187.

Wong MH, Henderson J, Drenth A. 2013 - Identification and differentiation of Phyllosticta species causing freckle disease of banana using high resolution melting (HRM) analysis. Plant Pathology 62, 1285-1293.

Wu S, Liu Y, Yuan J, Wang Y et al. 2014 - Phyllosticta species from banana (Musa sp.) in Chongqing and Guizhou Provinces. China. Phytotaxa 188, 135-44.

Wulandari NF, Bhat DJ, To-anun C. 2013 - A modern account of the genus Phyllosticta. Plant Pathology \& Quarantine 3, 145-159.

Wulandari NF, Hyde KD, Duong LM, De Gruyter J et al. 2009 - Phyllosticta citriasiana sp. nov., the cause of Citrus tan spot of Citrus maxima in Asia. Fungal Diversity 34, $23-39$.

Wulandari NF, To-anun C, Cai L, Abd-Elsalam KA, Hyde KD. 2010 - Guignardia/Phyllosticta species on banana. Cryptogamic Mycology 31, 403-418.

Xu J, Kjer J, Sendker J, Wray V et al. 2009 - Cytosporones, coumarins, and an alkaloid from the endophytic fungus Pestalotiopsis sp. isolated from the Chinese mangrove plant Rhizophora mucronata. Bioorganic \& Medicinal Chemistry 17, 7362-7367.

Yen JM. 1972 - Etude sur les champignons parasites du sud-est asiatique XVIII. Maladies des taches foliaires des bananiers provoquees, a Formose, par deux nouveaux champignons. III. Bulletin Société mycologique de France 88, 221-225.

Yu J, Wu Y, He Z, Li M et al. 2018 - Diversity and antifungal activity of endophytic fungi associated with Camellia oleifera. Mycobiology 46, 85-91.

Zeller SM. 1934 - Some new or noteworthy fungi on ericaceous hosts in the Pacific Northwest. Mycologia 26, 291-304.

Zhang K, Su YY, Cai L. 2013a - Morphological and phylogenetic characterization of two new species of Phyllosticta from China. Mycolgical Progress 12, 547-556.

Zhang K, Zhang N, Cai L. 2013b - Typification and phylogenetic study of Phyllosticta ampelicida and $P$. vaccinii. Mycologia 105, 1030-1042.

Zhou N, Chen Q, Carroll G, Zhang N et al. 2015 - Polyphasic characterization of four new plant pathogenic Phyllosticta species from China, Japan, and the United States. Fungal Biology 119, 433-446.

Zhu HY, Tian CM, Fan XL. 2018 - Studies of botryosphaerialean fungi associated with canker and dieback of tree hosts in Dongling Mountain of China. Phytotaxa 348, 63-76.

Zhuang WY. 2001 - Higher fungi of tropical China. Mycotaxon, Ltd., Ithaca, NY, 485 pages.

Zhuang WY. 2005 - Fungi of northwestern China. Mycotaxon, Ltd., Ithaca, NY, 430 pages. 


\section{Supplementary Tables and Figures}

Supplementary Table 1 Recorded geographic and host distributions of Phyllosticta species.

\begin{tabular}{|c|c|c|c|}
\hline Species record & Host & Locality & References \\
\hline \multicolumn{4}{|c|}{ Phyllosticta capitalensis species complex } \\
\hline P. acaciigena & Acacia suaveolens & Australia & Crous et al. (2016) \\
\hline P. aloeicola & Aloe ferox & South Africa & Wikee et al. (2013b) \\
\hline P. ardisiicola & Ardisia crenata & Japan & Motohashi et al. (2008) \\
\hline \multirow[t]{3}{*}{ P. aristolochiicola } & Aristolochia acuminata & Australia & Crous et al. (2012a) \\
\hline & Aristolochia clematitis & Australia & Wulandari et al. (2013) \\
\hline & Aristolochia sempervirens & Australia & Wulandari et al. (2013) \\
\hline \multirow[t]{2}{*}{ P. azevinhi } & Ilex azevinho & Madeira Islands & Spaulding (1961) \\
\hline & Ilex pedunculosa & Japan & Kobayashi (2007), Kobayashi \& Sasaki (1975), Motohashi et al. (2009) \\
\hline P. beaumarisii & Muehlenbeckia adpressa & Australia & Paul et al. (1986) \\
\hline P. brazilianiae & Mangifera indica & Brazil & Glienke et al. (2011) \\
\hline \multirow[t]{23}{*}{ P. capitalensis } & Acacia crassicarpa & Thailand & Wikee et al. (2013b) \\
\hline & Acer rubrum & Japan & Okane et al. (2003) \\
\hline & Acer sp. & Japan & Motohashi et al. (2009) \\
\hline & Aleurites fordii & Georgia & Wulandari et al. (2013) \\
\hline & Allamanda cathartica & India & Wulandari et al. (2013) \\
\hline & Allophylus sp. & South Africa & Wikee et al. (2013a) \\
\hline & Alnus serrulatoides & Japan & Okane et al. (2003) \\
\hline & Alocasia sp. & Thailand & Wikee et al. (2013a) \\
\hline & Amomum siamense & Thailand & Okane et al. (2003) \\
\hline & Amomum sp. & Thailand & Okane et al. (2003), Wikee et al. (2013a) \\
\hline & Amomum uliginosum & Thailand & Okane et al. (2003) \\
\hline & Ampelopsis sp. & United States & Wikee et al. (2013a) \\
\hline & Anacardium giganteum & Brazil & Rodrigues et al. (2004), Wulandari et al. (2009), Glienke et al. (2011) \\
\hline & Anacardium sp. & Brazil & Wikee et al. (2013a) \\
\hline & Anarcardium giganteum & Brazil & Sultan et al. (2011) \\
\hline & Anogeissus latifolia & India & Murali et al. (2007) \\
\hline & Anthocleista sp. & South Africa & Wikee et al. (2013a) \\
\hline & Anthurium sp. & Thailand & Wikee et al. (2013a) \\
\hline & Artocarpus sp. & Thailand & Shaw et al. (2006), Wikee et al. (2013a) \\
\hline & Arundina bambusifolia & Costa Rica & Cash \& Watson (1955), Thaung (2008a) \\
\hline & Arundina graminifolia & Japan & Okane et al. (2003) \\
\hline & Arundina sp. & Japan & Wikee et al. (2013a) \\
\hline & Aspidistra elatior & Japan & Motohashi et al. (2009) \\
\hline
\end{tabular}


Supplementary Table 1 Continued.

\begin{tabular}{|c|c|c|c|}
\hline Species record & Host & Locality & References \\
\hline & Aspidosperma polyneuron & Brazil & $\begin{array}{l}\text { Rodrigues et al. (2004), Wulandari et al. (2009), Wikee et al. (2011), Glienke } \\
\text { et al. (2011), Wikee et al. (2013a, b) }\end{array}$ \\
\hline & Aspidosperma sp. & Brazil & Wikee et al. (2013a) \\
\hline & Atropis distans & Georgia & Wulandari et al. (2013) \\
\hline & Baccaurea ramiflora & Thailand & Wikee et al. (2013b) \\
\hline & Banksia dryandroides & Hawaii & Crous et al. (2004) \\
\hline & Barringtonia racemosa & $\begin{array}{l}\text { South Africa, KwaZulu- } \\
\text { Natal }\end{array}$ & Shaw et al. (2006) \\
\hline & Barringtonia sp. & South Africa & Wikee et al. (2013a) \\
\hline & Bauhinia racemosa & India & Murali et al. (2007) \\
\hline & Berberis thunbergii & Japan & Okane et al. (2003) \\
\hline & Bifrenaria harrisoniae & Brazil & Silva et al. (2008) \\
\hline & Botrychium sp. & United States & Wikee et al. (2013a) \\
\hline & Bowdichia nitida & Brazil & $\begin{array}{l}\text { Rodrigues et al. (2004), Wulandari et al. (2009), Wikee et al. (2011), Glienke } \\
\text { et al. (2011), Wikee et al. (2013a, b) }\end{array}$ \\
\hline & Bowdichia sp. & Brazil & Wikee et al. (2013a) \\
\hline & Brassolaeliocattleya sp. & Florida & Alfieri Jr. et al. (1984) \\
\hline & Bumelia lycioides & Georgia, United States & Wulandari et al. (2013) \\
\hline & Butea monosperma & India & Murali et al. (2007) \\
\hline & Caesalpinia crista & Japan & Okane et al. (2003) \\
\hline & Caesalpinia sp. & Japan & Wikee et al. (2013a) \\
\hline & Calophyllum sp. & Thailand & Wikee et al. (2013a) \\
\hline & Camellia sinensis & $\begin{array}{l}\text { China, India, Japan, } \\
\text { Malawi, Papua New } \\
\text { Guinea, Taiwan }\end{array}$ & $\begin{array}{l}\text { Mathur (1979), Kobayashi (2007), Wiehe (1953), Shaw (1984), Anonymous } \\
\text { (1979), Cheng et al. (2019) }\end{array}$ \\
\hline & Camellia sp. & United States & Wikee et al. (2013a) \\
\hline & Canthium sp. & South Africa & Wikee et al. (2013a) \\
\hline & Capsicum sp. & Dominican Republic & Wulandari et al. (2009), Glienke et al. (2011), Wikee et al. (2013a) \\
\hline & Careya arborea & India & Murali et al. (2007) \\
\hline & Cariniana estrellensis & Brazil & Lisboa et al. (2016) \\
\hline & Cassia fistula & India & Murali et al. (2007) \\
\hline & Cassia occidentalis & Brazil & Rodrigues et al. (2004) \\
\hline & Cattleya skinneri & Guatemala & Cash \& Watson (1955) \\
\hline & Cattleya sp. & Florida & Alfieri Jr. et al. (1984) \\
\hline & Cerbera manghas & Japan & Okane et al. (2003) \\
\hline & Cerbera sp. & Japan & Wikee et al. (2013a) \\
\hline
\end{tabular}


Supplementary Table 1 Continued.

\begin{tabular}{|c|c|c|c|}
\hline Species record & Host & Locality & References \\
\hline & Cercidiphyllum japonicum & Japan & Motohashi et al. (2009) \\
\hline & Cercidiphyllum sp. & Japan & Wikee et al. (2013a) \\
\hline & Cercis canadensis & Japan & Motohashi et al. (2009) \\
\hline & Cercis sp. & Japan & Wikee et al. (2013a) \\
\hline & Cinnamomum camphora & Japan & Okane et al. (2003) \\
\hline & Cinnamomum japonicum & Japan & Okane et al. (2003) \\
\hline & Cinnamomum sp. & Japan & Wikee et al. (2013a) \\
\hline & Citrus $\times$ paradisi & $\begin{array}{l}\text { Florida, South Africa, } \\
\text { KwaZulu-Natal, South } \\
\text { Africa, Mpumalanga }\end{array}$ & Peres et al. (2007), Meyer et al. (2006) \\
\hline & Citrus $\times$ paradisi-reticulata & New Zealand & Everett \& Rees-George (2006) \\
\hline & Citrus aurantifolia & Italy, New Zealand & $\begin{array}{l}\text { Guarnaccia et al. (2017), Tran et al. (2019), Wikee et al. (2013b), Wulandari } \\
\text { et al. (2009), Glienke et al. (2011) }\end{array}$ \\
\hline & Citrus aurantium & Australia, Brazil, Thailand & $\begin{array}{l}\text { Rodrigues et al. (2004), Wulandari et al. (2009), Miles et al. (2013), Tran et } \\
\text { al. (2019), Glienke et al. (2011), Guarnaccia et al. (2017) }\end{array}$ \\
\hline & Citrus latifolia & Brazil & Glienke et al. (2011), Wikee et al. (2013a) \\
\hline & Citrus limon & $\begin{array}{l}\text { South Africa, Eastern } \\
\text { Cape, Taiwan, Argentina, } \\
\text { Australia, Greece, Italy, } \\
\text { Malta, Portugal, Spain }\end{array}$ & $\begin{array}{l}\text { Meyer et al. (2006), Wulandari et al. (2009), Wikee et al. (2013b), Zhou et al. } \\
\text { (2015), Hyde et al. (2014), Miles et al. (2013), Tran et al. (2019), Guarnaccia } \\
\text { et al. (2017) }\end{array}$ \\
\hline & Citrus limonia & Brazil & Glienke et al. (2011) \\
\hline & $\begin{array}{l}\text { Citrus medica var. } \\
\text { sarcodactylis }\end{array}$ & Italy & Guarnaccia et al. (2017) \\
\hline & Citrus paradisi & Florida & Wulandari et al. (2009), Glienke et al. (2011) \\
\hline & Citrus reticulata & Australia, Brazil & $\begin{array}{l}\text { Miles et al. (2013), Tran et al. (2019), Glienke et al. (2011), Wikee et al. } \\
\text { (2013a) }\end{array}$ \\
\hline & Citrus sinensis & Brazil, Florida & Glienke et al. (2011), Wikee et al. (2013a, b), Guarnaccia et al. (2017) \\
\hline & Citrus sp. & $\begin{array}{l}\text { Argentina, Australia, } \\
\text { Brazil, China, Hong Kong, } \\
\text { New Zealand, South } \\
\text { Africa, Taiwan, Thailand, } \\
\text { United States }\end{array}$ & $\begin{array}{l}\text { Wulandari et al. (2009), Wikee et al. (2011, 2013a), Glienke et al. (2011), } \\
\text { Guarnaccia et al. (2017) }\end{array}$ \\
\hline & Clethra barbinervis & Japan & Okane et al. (2003) \\
\hline & Cliffortia sp. & South Africa & Wikee et al. (2013a) \\
\hline & Clutia sp. & South Africa & Wikee et al. (2013a) \\
\hline & Cocculus sp. & United States & Wikee et al. (2013a) \\
\hline
\end{tabular}


Supplementary Table 1 Continued.

\begin{tabular}{|c|c|c|c|}
\hline Species record & Host & Locality & References \\
\hline & Codiaeum sp. & Thailand & Wikee et al. (2013a) \\
\hline & Coelogyne sp. & Philippines, Thailand & Cash \& Watson (1955), Shaw et al. (2006), Wikee et al. (2013a) \\
\hline & Combretum sp. & South Africa & Wikee et al. (2013a) \\
\hline & Comocladia sp. & Puerto Rico & Wikee et al. (2013a) \\
\hline & Coprosma sp. & Hawaii & Wikee et al. (2013a) \\
\hline & Cordia obliqua & India & Murali et al. (2007) \\
\hline & Cordia sp. & South Africa & Wikee et al. (2013a) \\
\hline & Cordia wallichii & India & Murali et al. (2007) \\
\hline & Cordyline fruticosa & Thailand & Wikee et al. (2013b) \\
\hline & Coriaria terminalis & Japan & Okane et al. (2003) \\
\hline & Cornus kousa & Japan & Okane et al. (2003) \\
\hline & Corylopsis sinensis & Japan & Okane et al. (2003) \\
\hline & Corylus sieboldiana & Japan & Okane et al. (2003) \\
\hline & Cotinus coggygria var. cinerea & Japan & Okane et al. (2003) \\
\hline & Crinum asiaticum & Thailand & Wikee et al. (2013b) \\
\hline & Crinum sp. & Thailand & Liu et al. (2012) \\
\hline & Croton sp. & South Africa & Wikee et al. (2013a) \\
\hline & Ctenomeria sp. & South Africa & Wikee et al. (2013a) \\
\hline & Curtisia sp. & South Africa & Wikee et al. (2013a) \\
\hline & Cussonia sp. & South Africa, Gauteng & Meyer et al. (2006), Wikee et al. (2013a) \\
\hline & Cymbidium sp. & Brazil, Florida, India & $\begin{array}{l}\text { Alfieri Jr. et al. (1984), Silva \& Pereira (2007), Glienke et al. (2011), Wikee } \\
\text { et al. (2013b) }\end{array}$ \\
\hline & Cyphostemma sp. & South Africa & Wikee et al. (2013a) \\
\hline & Cypripedium insigne & India & Cash \& Watson (1955) \\
\hline & Cypripedium sp. & Japan & Cash \& Watson (1955) \\
\hline & Dalbergia lanceolaria & India & Murali et al. (2007) \\
\hline & Daphniphyllum teijsmanni & Japan & Okane et al. (2003) \\
\hline & Davidia involucrata & Japan & Okane et al. (2003), Motohashi et al. (2009) \\
\hline & Davidia sp. & Japan & Wikee et al. (2013a) \\
\hline & Dendrobium canaliculatum & Australia & Cash \& Watson (1955) \\
\hline & Dendrobium phalaenopsis & $\begin{array}{l}\text { Australia, Belgium, } \\
\text { Philippines }\end{array}$ & Nag Raj (1993), Cash \& Watson (1955) \\
\hline & Dendrobium schuetzei & Philippines & Cash \& Watson (1955) \\
\hline & Dendrobium sp. & $\begin{array}{l}\text { Brunei Darussalam, } \\
\text { Thailand, Florida, Haiti, } \\
\text { Samoa }\end{array}$ & $\begin{array}{l}\text { Peregrine \& Ahmad (1982), Wikee et al. (2013a), Alfieri Jr. et al. (1984), } \\
\text { Benjamin \& Slot (1969), Cash \& Watson (1955) }\end{array}$ \\
\hline
\end{tabular}


Supplementary Table 1 Continued.

\begin{tabular}{|c|c|c|c|}
\hline Species record & Host & Locality & References \\
\hline & Dendrobium undulatum & Australia & Cash \& Watson (1955) \\
\hline & Dendropanax trifidus & Japan & Motohashi et al. (2009) \\
\hline & Dieffenbachia sp. & Thailand & Wikee et al. (2013a) \\
\hline & Diospyros kaki & Taiwan & Duan et al. (2017) \\
\hline & Diospyros montana & India & Murali et al. (2007) \\
\hline & Diospyros sp. & South Africa & Wikee et al. (2013a) \\
\hline & Dodonaea sp. & Hawaii & Wikee et al. (2013a) \\
\hline & Dovyalis sp. & South Africa & Wikee et al. (2013a) \\
\hline & Dracontomelon mangiferum & Myanmar & Thaung (2008b) \\
\hline & Ekebergia sp. & South Africa & Wikee et al. (2013a) \\
\hline & Elaeis guineensis & Malaysia & Nasehi et al. (2020) \\
\hline & Elaeocarpus glabripetalus & China & Lou et al. (2009) \\
\hline & Elaeodendron glaucum & India & Murali et al. (2007) \\
\hline & Encephalartos ferox & South Africa & Glienke et al. (2011) \\
\hline & Encephalartos sp. & South Africa & Wikee et al. (2013a) \\
\hline & Enkianthus sp. & Japan & Wikee et al. (2013a) \\
\hline & Epidendrum fragrans & Jamaica & Cash \& Watson (1955) \\
\hline & Epidendrum sp. & Florida, Mexico & Alfieri Jr. et al. (1984), Cash \& Watson (1955) \\
\hline & Eriobotrya japonica & Japan & Motohashi et al. (2009) \\
\hline & Eriobotrya sp. & Japan & Wikee et al. (2013a) \\
\hline & Erythroxylum monogynum & India & Murali et al. (2007) \\
\hline & Eucalyptus dives & South Africa & Wulandari et al. (2013) \\
\hline & Eucalyptus grandis & Brazil & Wikee et al. (2013b) \\
\hline & Eucalyptus sp. & Brazil, South Africa & Wikee et al. (2013a) \\
\hline & Euclea sp. & South Africa & Wikee et al. (2013a) \\
\hline & Euonymus alatus & Japan & Okane et al. (2003) \\
\hline & Euphorbia milii & Thailand & Wikee et al. (2013a, b), Guarnaccia et al. (2017) \\
\hline & Euphorbia sp. & Thailand & Wikee et al. (2013a) \\
\hline & Eurya japonica & Japan & Okane et al. (2003) \\
\hline & Fagus crenata & Japan & Okane et al. (2003) \\
\hline & Fagus japonica & Japan & Okane et al. (2003) \\
\hline & Ficus benjamina & Thailand & Wikee et al. (2013a, b) \\
\hline & Ficus sp. & Thailand & Wikee et al. (2013a) \\
\hline & Forsythia koreana & Japan & Okane et al. (2003) \\
\hline & Forsythia viridissima & Japan & Okane et al. (2003) \\
\hline
\end{tabular}


Supplementary Table 1 Continued.

\begin{tabular}{|c|c|c|c|}
\hline Species record & Host & Locality & References \\
\hline & Fortunella sp. & $\begin{array}{l}\text { South Africa, } \\
\text { Mpumalanga, United } \\
\text { States }\end{array}$ & Meyer et al. (2006), Wikee et al. (2013a) \\
\hline & $\begin{array}{l}\text { Gardenia jasminoides var. } \\
\text { radicans }\end{array}$ & Japan & Okane et al. (2003) \\
\hline & Gardenia sp. & South Africa & Wikee et al. (2013a) \\
\hline & Ginkgo biloba & Japan, Taiwan & Motohashi et al. (2009), Kirschner (2018) \\
\hline & Ginkgo sp. & Japan & Wikee et al. (2013a) \\
\hline & Givotia rottleriformis & India & Murali et al. (2007) \\
\hline & Gmelina arborea & India & Murali et al. (2007) \\
\hline & Grevillea robusta & Hawaii & Crous et al. (2004, 2013) \\
\hline & Grevillea sp. & Australia, Tasmania & Crous et al. (2004, 2013) \\
\hline & Grewia sp. & South Africa & Wikee et al. (2013a) \\
\hline & Grewia tiliifolia & India & Murali et al. (2007) \\
\hline & Guzmania sp. & Florida & Alfieri Jr. et al. (1984) \\
\hline & Hebe sp. & South Africa & Wikee et al. (2013a) \\
\hline & Hedera helix & Italy & Wulandari et al. (2009) \\
\hline & Hedera sp. & South Africa & Wikee et al. (2013a) \\
\hline & Heliconia sp. & Thailand & Wikee et al. (2013b) \\
\hline & Helicteres isora & India & Murali et al. (2007) \\
\hline & Helicteres jamaicensis & Puerto Rico & Wulandari et al. (2013) \\
\hline & Helicteres sp. & Puerto Rico & Wulandari et al. (2013) \\
\hline & Heptapleurum venulosum & Pakistan & Wulandari et al. (2013) \\
\hline & Hibiscus sp. & Thailand & Wikee et al. (2013a) \\
\hline & Hibiscus syriacus & Thailand & Wikee et al. (2013a, b), Guarnaccia et al. (2017) \\
\hline & Hydrangea quercifolia & Japan & Motohashi et al. (2009) \\
\hline & Hypericum androsaemum & Japan & Okane et al. (2003) \\
\hline & Ilex rotunda & Japan & Okane et al. (2003) \\
\hline & Ilex serrata & Japan & Okane et al. (2003) \\
\hline & Ilex sp. & United States & Wikee et al. (2013a) \\
\hline & Ipomoea sp. & Malaysia & Wikee et al. (2013a) \\
\hline & Itea sp. & United States & Wikee et al. (2013a) \\
\hline & Ixora chinensis & Thailand & Wikee et al. (2013b), Guarnaccia et al. (2017) \\
\hline & Ixora nigricans & India & Murali et al. (2007) \\
\hline & Jacquiniella sp. & Panama & Cash \& Watson (1955), Piepenbring (2006) \\
\hline & Juglans mandshurica & Japan & Okane et al. (2003) \\
\hline
\end{tabular}


Supplementary Table 1 Continued.

\begin{tabular}{|c|c|c|c|}
\hline Species record & Host & Locality & References \\
\hline & Kandelia candel & Japan & Okane et al. (2003) \\
\hline & Kandelia sp. & Japan & Wikee et al. (2013a) \\
\hline & Koelreuteria paniculata & Japan & Okane et al. (2003) \\
\hline & Kydia calycina & India & Murali et al. (2007) \\
\hline & Laelia anceps & Mexico & Cash \& Watson (1955) \\
\hline & Laelia sp. & Florida & Alfieri Jr. et al. (1984) \\
\hline & Laeliocattleya sp. & Florida & Alfieri Jr. et al. (1984) \\
\hline & Lagerstroemia microcarpa & India & Murali et al. (2007) \\
\hline & Lagerstroemia parviflora & India & Murali et al. (2007) \\
\hline & $\begin{array}{l}\text { Leucadendron } \times \text { laureolum- } \\
\text { salignum }\end{array}$ & Hawaii & Crous et al. (2013) \\
\hline & Leucadendron sp. & $\begin{array}{l}\text { Australia, Hawaii, } \\
\text { Tasmania }\end{array}$ & Crous et al. $(2004,2013)$ \\
\hline & $\begin{array}{l}\text { Leucospermum cordifolium- } \\
\text { glabrum }\end{array}$ & Hawaii & Crous et al. (2013) \\
\hline & $\begin{array}{l}\text { Leucospermum cordifolium- } \\
\text { patersonii }\end{array}$ & Hawaii & Crous et al. (2013) \\
\hline & Leucospermum sp. & $\begin{array}{l}\text { Australia, Hawaii, } \\
\text { Tasmania }\end{array}$ & Wikee et al. (2013a), Crous et al. (2004, 2013) \\
\hline & Ligustrum lucidum & Japan & Motohashi et al. (2009) \\
\hline & Ligustrum sp. & Japan & Wikee et al. (2013a) \\
\hline & Lindera strychnifolia & Japan & Okane et al. (2003) \\
\hline & Lindera umbellata & Japan & Okane et al. (2003) \\
\hline & Litchi sp. & South Africa & Wikee et al. (2013a) \\
\hline & Lithocarpus edulis & Japan & Motohashi et al. (2009) \\
\hline & Lithocarpus sp. & Japan & Wikee et al. (2013a) \\
\hline & Livistona sp. & Thailand & Wikee et al. (2013a) \\
\hline & Lonicera morrowii & Japan & Okane et al. (2003) \\
\hline & Loxostylis sp. & South Africa & Wikee et al. (2013a) \\
\hline & Macfadyena unguis-cati & Brazil & da Silva et al. (2012) \\
\hline & Mackaya sp. & South Africa & Wikee et al. (2013a) \\
\hline & Maerua sp. & South Africa & Wikee et al. (2013a) \\
\hline & Magnolia grandiflora & Iran & Esmaeilzadeh et al. (2020) \\
\hline & Magnolia liliifera & Thailand & Wulandari et al. (2009), Glienke et al. (2011), Wikee et al. (2011) \\
\hline & Magnolia praecocissima & Japan & Okane et al. (2003) \\
\hline & Magnolia salicifolia & Japan & Okane et al. (2003) \\
\hline
\end{tabular}


Supplementary Table 1 Continued.

\begin{tabular}{|c|c|c|c|}
\hline Species record & Host & Locality & References \\
\hline & Magnolia sp. & Thailand, United States & Wikee et al. (2013a) \\
\hline & Mangifera indica & $\begin{array}{l}\text { Brazil, Florida, Japan, } \\
\text { India, Malaysia, Mexico, } \\
\text { Myanmar, South Africa, } \\
\text { Mpumalanga, Taiwan }\end{array}$ & $\begin{array}{l}\text { Sivanesan (1984), Watson (1971), Roy (1967), Glienke et al. (2011), Wikee } \\
\text { et al. (2011, 2013a), Miles et al. (2013), Zhou et al. (2015), Hyde et al. } \\
\text { (2014), Liu (1977), Thaung (2008b), Meyer et al. (2006), Sivanesan \& Hsieh } \\
\text { (1989), Nag Raj (1993), van der Aa (1973), Kobayashi (2007), Alfieri Jr. et } \\
\text { al. (1984), McGuire \& Crandall (1967) }\end{array}$ \\
\hline & Mangifera sp. & Brazil, Ghana & Wikee et al. (2013a) \\
\hline & Michelia fuscata & Japan & Okane et al. (2003) \\
\hline & Michelia sp. & Thailand & Wikee et al. (2013a) \\
\hline & Monanthotaxis sp. & South Africa & Wikee et al. (2013a) \\
\hline & Morus alba & Japan & Okane et al. (2003) \\
\hline & Morus latifolia & Japan & Okane et al. (2003) \\
\hline & Morus sp. & Thailand & Wikee et al. (2013a) \\
\hline & Musa acuminata & $\begin{array}{l}\text { China, Hawaii, Indonesia, } \\
\text { Indonesia, South Africa, } \\
\text { KwaZulu-Natal, South } \\
\text { Africa, Mpumalanga, } \\
\text { Thailand }\end{array}$ & $\begin{array}{l}\text { Okane et al. (2003), Meyer et al. (2006), Wulandari et al. (2009), Sun et al. } \\
\text { (2016), Wikee et al. (2013b), Glienke et al. (2011), Wikee et al. (2013b), } \\
\text { Miles et al. (2013) }\end{array}$ \\
\hline & Musa paradisiaca & Thailand & $\begin{array}{l}\text { Wulandari et al. (2009), Glienke et al. (2011), Wikee et al. (2011), Wikee et } \\
\text { al. (2013a, b), Guarnaccia et al. (2017) }\end{array}$ \\
\hline & Musa sp. & $\begin{array}{l}\text { Hawaii, Indonesia, } \\
\text { Thailand, United States }\end{array}$ & Crous et al. (2004), Glienke et al. (2011), Wikee et al. (2013a) \\
\hline & Myracrodruon sp. & Brazil & Wikee et al. (2013a) \\
\hline & Myracrodruon urundeuva & Brazil & $\begin{array}{l}\text { Rodrigues et al. (2004), Wulandari et al. (2009), Glienke et al. (2011), Wikee } \\
\text { et al. (2011, 2013a, b), Miles et al. (2013) }\end{array}$ \\
\hline & Myrica rubra & Japan & Okane et al. (2003) \\
\hline & Nandina domestica & Japan & Okane et al. (2003) \\
\hline & $\begin{array}{l}\text { Nandina domestica var. } \\
\text { leucocarpa }\end{array}$ & Japan & Okane et al. (2003) \\
\hline & Naringi crenulata & India & Murali et al. (2007) \\
\hline & Nephelium lappaceum & Hawaii & $\begin{array}{l}\text { Wulandari et al. (2009), Glienke et al. (2011), Wikee et al. (2013b), } \\
\text { Guarnaccia et al. (2017) }\end{array}$ \\
\hline & Nephelium sp. & United States & Wikee et al. (2013a) \\
\hline & Nerium oleander var. indicum & Japan & Motohashi et al. (2009) \\
\hline & Nerium sp. & Japan & Wikee et al. (2013a) \\
\hline & Nidularium sp. & Florida & Alfieri Jr. et al. (1984) \\
\hline
\end{tabular}


Supplementary Table 1 Continued.

\begin{tabular}{|c|c|c|c|}
\hline Species record & Host & Locality & References \\
\hline & Ocotea sp. & South Africa & Wikee et al. (2013a) \\
\hline & Odontoglossum sp. & Florida & Alfieri Jr. et al. (1984) \\
\hline & Oncidium sp. & Florida, Panama & Alfieri Jr. et al. (1984), Cash \& Watson (1955), Piepenbring (2006) \\
\hline & Ophiopogon sp. & Thailand & Wikee et al. (2013a) \\
\hline & Orchidaceae & Florida & Alfieri Jr. et al. (1984) \\
\hline & Orchidaceae & Japan & Okane et al. (2003) \\
\hline & Orixa japonica & Japan & Okane et al. (2003) \\
\hline & $\begin{array}{l}\text { Osmanthus fragrans var. } \\
\text { aurantiacus f. aurantiacus }\end{array}$ & Japan & Motohashi et al. (2009) \\
\hline & Ougeinia oojeinensis & India & Murali et al. (2007) \\
\hline & Pandanus sp. & Thailand & Hyde et al. (2018) \\
\hline & Paphiopedilum callosum & Germany & $\begin{array}{l}\text { Wulandari et al. (2009), Glienke et al. (2011), Wikee et al. (2013a, b), } \\
\text { Guarnaccia et al. (2017) }\end{array}$ \\
\hline & Paphiopedilum sp. & Germany & Wikee et al. (2013a) \\
\hline & Parinari sp. & South Africa & Wikee et al. (2013a) \\
\hline & Paullinia cupana & Brazil & Wikee et al. (2013a) \\
\hline & Pavetta sp. & South Africa & Wikee et al. (2013a) \\
\hline & Persea americana & South Africa, Mpumalanga & Meyer et al. (2006) \\
\hline & Phalaenopsis sp. & Florida & Alfieri Jr. et al. (1984) \\
\hline & Phellodendron amurense & Japan & Okane et al. (2003) \\
\hline & Philodendron sp. & Thailand & Wikee et al. (2013a, b) \\
\hline & Picrasma quassioides & Japan & Okane et al. (2003) \\
\hline & Piper sp. & Puerto Rico & Wulandari et al. (2013) \\
\hline & Pittosporum sp. & Hawaii, Japan & Wikee et al. (2013a) \\
\hline & Pittosporum tobira & Japan & Motohashi et al. (2009) \\
\hline & Podocarpus macrophyllus & Japan & Okane et al. (2003) \\
\hline & Podocarpus sp. & South Africa & Wikee et al. (2013a) \\
\hline & Polyalthia longifolia & Thailand & Wikee et al. (2013a, b), Guarnaccia et al. (2017) \\
\hline & Polyalthia sp. & Thailand & Wikee et al. (2013a) \\
\hline & Polyscias sp. & Thailand & Wikee et al. (2013a, b) \\
\hline & Premna tomentosa & India & Murali et al. (2007) \\
\hline & Protea $\times$ compacta-susannae & Hawaii & Crous et al. (2013) \\
\hline & Protea cynaroides & Hawaii & Crous et al. $(2004,2013)$ \\
\hline & Protea repens & Portugal & Wikee et al. (2013b) \\
\hline & Protea sp. & Hawaii & Wikee et al. (2013a) \\
\hline & Prunus cerasoides & Thailand & Okane et al. (2003) \\
\hline
\end{tabular}


Supplementary Table 1 Continued.

\begin{tabular}{|c|c|c|c|}
\hline Species record & Host & Locality & References \\
\hline & $\begin{array}{l}\text { Prunus laurocerasus var. } \\
\text { angustifolia }\end{array}$ & Japan & Okane et al. (2003) \\
\hline & Prunus sp. & Japan & Wikee et al. (2013a) \\
\hline & Psidium guajava & Brazil, India, Venezuela & $\begin{array}{l}\text { Wulandari et al. (2009), Wikee et al. (2011), Glienke et al. (2011), Pande } \\
\text { (2008), Gonzalez \& Rondon (2005) }\end{array}$ \\
\hline & Psidium sp. & Brazil & Wikee et al. (2013a) \\
\hline & Punica granatum & Japan, Thailand & Okane et al. (2003), Wikee et al. (2013a, b) \\
\hline & Punica granatum var. nana & Japan & Okane et al. (2003) \\
\hline & Punica sp. & Thailand & Wikee et al. (2013a) \\
\hline & Putterlickia sp. & South Africa & Wikee et al. (2013a) \\
\hline & Pyrrosia adnascens & Thailand & Wikee et al. (2013b) \\
\hline & Quercus dentata & Japan & Okane et al. (2003) \\
\hline & Quercus variabilis & Japan & Okane et al. (2003) \\
\hline & Rauvolfia sp. & South Africa & Wikee et al. (2013a) \\
\hline & Rhododendron $\times$ pulchrum & Japan & Wulandari et al. (2013) \\
\hline & Rhododendron indicum & Japan & Okane et al. (2003) \\
\hline & Rhododendron simsii & Japan & Okane et al. (2003) \\
\hline & Rhododendron sp. & Brazil, Japan & Rodrigues et al. (2004), Sultan et al. (2011), Wikee et al. (2013a) \\
\hline & Rhoicissus sp. & South Africa & Wikee et al. (2013a) \\
\hline & Rhus sp. & South Africa & Wikee et al. (2013a) \\
\hline & Rhynchostylis sp. & Malaysia & Liu (1977), Wikee et al. (2013a) \\
\hline & Ricinus communis & China & Tang et al. (2020) \\
\hline & Robinia pseudoacacia & Japan & Motohashi et al. (2009) \\
\hline & Rothmannia sp. & South Africa & Wikee et al. (2013a) \\
\hline & Rubus croceacanthus & Japan & Okane et al. (2003) \\
\hline & Rubus sp. & Japan & Wikee et al. (2013a) \\
\hline & Saccharum officinarum & Thailand & Wikee et al. (2013a, b) \\
\hline & Saccharum sp. & Thailand & Wikee et al. (2013a) \\
\hline & Sambucus nigra & Japan & Okane et al. (2003) \\
\hline & Sansevieria hyacinthoides & Thailand & Wikee et al. (2013a) \\
\hline & Sansevieria sp. & Netherlands, Thailand & Wulandari et al. (2009), Wikee et al. (2013a, b) \\
\hline & Schefflera venulosa & Thailand & Wikee et al. (2013b) \\
\hline & Schomburgkia sp. & $\begin{array}{l}\text { Cayman, Islands, West } \\
\text { Indies }\end{array}$ & Cash \& Watson (1955) \\
\hline & Schomburgkia tibicinis & Mexico & Cash \& Watson (1955) \\
\hline & Schrebera sp. & South Africa & Wikee et al. (2013a) \\
\hline
\end{tabular}


Supplementary Table 1 Continued.

\begin{tabular}{|c|c|c|c|}
\hline Species record & Host & Locality & References \\
\hline & Sclerocarya sp. & South Africa & Wikee et al. (2013a) \\
\hline & Scutia sp. & South Africa & Wikee et al. (2013a) \\
\hline & Secamone sp. & South Africa & Wikee et al. (2013a) \\
\hline & Smilax aspera & India & Wulandari et al. (2013) \\
\hline & Smilax china & Japan & Okane et al. (2003) \\
\hline & Smilax kraussiana & South Africa & Glienke et al. (2011) \\
\hline & Smilax sp. & South Africa & Wikee et al. (2013a) \\
\hline & Sophora japonica & Japan & Okane et al. (2003) \\
\hline & Sorbus commixta & Japan & Okane et al. (2003) \\
\hline & Spathiphyllum sp. & Japan & Motohashi et al. (2009), Wikee et al. (2013a) \\
\hline & Spondias mombin & Brazil, Indonesia & $\begin{array}{l}\text { Rodrigues et al. (2004), Wulandari et al. (2009), Wikee et al. (2011), Glienke } \\
\text { et al. (2011), Ismail et al. (2012, 2013), Miles et al. (2013) }\end{array}$ \\
\hline & Spondias sp. & Brazil & Wikee et al. (2013a) \\
\hline & Stangeria sp. & South Africa & Wikee et al. (2013a) \\
\hline & Stanhopea graveolens & Brazil & Glienke et al. (2011), Wikee et al. (2011, 2013a, b), Miles et al. (2013) \\
\hline & Stanhopea sp. & Brazil, Costa Rica & $\begin{array}{l}\text { Cash \& Watson (1955), Nag Raj (1993), Glienke et al. (2011), Wikee et al. } \\
\text { (2011, 2013a, b), Zhou et al. (2015), Guarnaccia et al. (2017), Tran et al. } \\
\text { (2019), Hyde et al. (2014) }\end{array}$ \\
\hline & Sterculia sp. & Puerto Rico & Wikee et al. (2013a) \\
\hline & Stereospermum angustifolium & India & Murali et al. (2007) \\
\hline & Strychnos potatorum & India & Murali et al. (2007) \\
\hline & Strychnos sp. & South Africa & Wikee et al. (2013a) \\
\hline & Sumbaviopsis albicans & Puerto Rico & Wulandari et al. (2013) \\
\hline & Syringa reticulata & Iran & Esmaeilzadeh et al. (2020) \\
\hline & Syzygium cumini & India & Murali et al. (2007) \\
\hline & Syzygium sp. & Madagascar & Wikee et al. (2013b) \\
\hline & Tectona grandis & India, Thailand & Murali et al. (2007), Wikee et al. (2013a, b), Hyde et al. (2018) \\
\hline & Telopea sp. & $\begin{array}{l}\text { Australia, Hawaii, } \\
\text { Tasmania, Thailand }\end{array}$ & Wikee et al. (2013a), Crous et al. (2004, 2013) \\
\hline & Terminalia crenulata & India & Murali et al. (2007) \\
\hline & Thea sinensis & China, USSR & Watson (1971), Jin (2011) \\
\hline & $\begin{array}{l}\text { Thujopsis dolabrata var. } \\
\text { hondai }\end{array}$ & Japan & Okane et al. (2003) \\
\hline & Tilia miqueliana & Japan & Okane et al. (2003) \\
\hline & Tinospora crispa & Thailand & Wikee et al. (2013a) \\
\hline & Tinospora sp. & Thailand & Wikee et al. (2013a) \\
\hline
\end{tabular}


Supplementary Table 1 Continued.

\begin{tabular}{|c|c|c|c|}
\hline Species record & Host & Locality & References \\
\hline & Trema sp. & South Africa & Wikee et al. (2013a) \\
\hline & Trichilia sp. & South Africa & Wikee et al. (2013a) \\
\hline & Tsuga sieboldii & Japan & Okane et al. (2003) \\
\hline & unknown, Pteridophyta & Japan & Okane et al. (2003) \\
\hline & Vaccinium sp. & New Zealand & $\begin{array}{l}\text { Wulandari et al. (2009), Glienke et al. (2011), Wikee et al. (2013a, b), } \\
\text { Guarnaccia et al. (2017), Tran et al. (2019) }\end{array}$ \\
\hline & Vagnera stellata & New York, United States & Wulandari et al. (2013), Wulandari et al. (2013) \\
\hline & Vanda sp. & Brunei Darussalam, Florida & Peregrine \& Ahmad (1982), Alfieri Jr. et al. (1984) \\
\hline & Vinca minor & South Africa & Shaw et al. (2006) \\
\hline & Viscum sp. & South Africa & Wikee et al. (2013a) \\
\hline & Vitex agnus-castus & Japan & Okane et al. (2003) \\
\hline & Vitex cannabifolia & Japan & Okane et al. (2003) \\
\hline & Vitex sp. & Malaysia, South Africa & Wikee et al. (2013a) \\
\hline & Xymalos sp. & South Africa & Wikee et al. (2013a) \\
\hline & Zanthoxylum armatum & Japan & Okane et al. (2003) \\
\hline & Zanthoxylum sp. & Japan, Puerto Rico & Wikee et al. (2013a) \\
\hline & Zingiber officinale & Thailand & Okane et al. (2003) \\
\hline & Ziziphus sp. & South Africa, Thailand & Wikee et al. (2013a) \\
\hline & Ziziphus xylopyrus & India & Murali et al. (2007) \\
\hline P. carochlae & Caryota ochlandra & China & Zhou et al. (2015) \\
\hline P. cavendishii & Musa sp. & Australia & Wong et al. (2013) \\
\hline \multirow[t]{8}{*}{ P. cordylinophila } & Cordyline atropurpurea & Japan & Wikee et al. (2013b) \\
\hline & Cordyline australis & Hawaii, New Zealand & Nag Raj (1993), Pennycook (1989) \\
\hline & Cordyline banksii & New Zealand & Pennycook (1989) \\
\hline & Cordyline dracaenoides & Argentina & Farr (1973) \\
\hline & Cordyline fruticosa & Japan, Thailand & Motohashi et al. (2009), Wikee et al. (2013b) \\
\hline & Cordyline terminalis & $\begin{array}{l}\text { Hawaii, India, Japan, } \\
\text { Samoa, Tonga }\end{array}$ & Dingley et al. (1981), Mathur (1979), Raabe (1981), Kobayashi (2007) \\
\hline & Crinum pedunculatum & Australia & Simmonds (1966) \\
\hline & Dracaena sp. & $\begin{array}{l}\text { Puerto Rico, Virgin } \\
\text { Islands, West Indies }\end{array}$ & Stevenson (1975), Minter et al. (2001) \\
\hline \multirow[t]{5}{*}{ P. eugeniae } & Eugenia aromatica & Indonesia & Sultan et al. (2011) \\
\hline & Eugenia cumini & Taiwan & Anonymous (1979) \\
\hline & Eugenia maleolens & Puerto Rico, Virgin Islands & Stevenson (1975) \\
\hline & Eugenia sp. & Florida & Alfieri Jr et al. (1984) \\
\hline & Eugenia uniflora & Florida & Alfieri Jr et al. (1984) \\
\hline
\end{tabular}


Supplementary Table 1 Continued.

\begin{tabular}{|c|c|c|c|}
\hline Species record & Host & Locality & References \\
\hline & Syzygium cumini & Florida & Alfieri Jr et al. (1984) \\
\hline & Syzygium jambos & Florida & Alfieri Jr et al. (1984) \\
\hline P. fallopiae & Fallopia japonica & Japan & $\begin{array}{l}\text { Motohashi et al. (2008, 2009), Wikee et al. (2011), Zhou et al. (2015), Hyde } \\
\text { et al. (2014) }\end{array}$ \\
\hline P. ilicis-aquifolii & Ilex aquifolium & China, United Kingdom & Wikee et al. (2013b), Zhou et al. (2015), Hyde et al. (2014), Su \& Cai (2012) \\
\hline \multirow[t]{22}{*}{ P. maculata } & Musa acuminata & $\begin{array}{l}\text { Australia, Hawaii, } \\
\text { Indonesia }\end{array}$ & Shivas (1989), Raabe et al. (1981), Wulandari et al. (2010) \\
\hline & Musa sapientum & Thailand & Giatgong (1980) \\
\hline & Musa sp. & $\begin{array}{l}\text { Australia, Bangladesh, } \\
\text { Bhutan, Brunei }\end{array}$ & $\begin{array}{l}\text { Hyde \& Alcorn (1993), Wulandari et al. (2010), Sivanesan (1984), Photita et } \\
\text { al. (2002), Dingley et al. (1981), Meredith (1969), Rabe et al. (1981), }\end{array}$ \\
\hline & & Darussalam, China, & Stevens (1925), Thaung (2008b), Shaw (1984), McKenzie (1996), Ebbels \& \\
\hline & & $\begin{array}{l}\text { Christmas Island, Territory } \\
\text { of, Congo, Democratic }\end{array}$ & Allen (1979) \\
\hline & & Republic of the, Cook & \\
\hline & & Islands, Fiji, Hawaii, Hong & \\
\hline & & Kong, India,Indonesia, & \\
\hline & & Malaysia, Micronesia, & \\
\hline & & Caledonia, New Guinea, & \\
\hline & & New Zealand, Niue, & \\
\hline & & Pakistan, Palau, Papua & \\
\hline & & New Guinea, Philippines, & \\
\hline & & Samoa, Solomon Islands, & \\
\hline & & Sri Lanka, Taiwan, & \\
\hline & & Tanzania, Thailand, Tonga, & \\
\hline & & Vanuatu, Vietnam & \\
\hline & Musa $\times$ paradisiaca & Hawaii, Indonesia & Anonymous (1960), Goos \& Gowing (1992), Photita et al. (2002) \\
\hline & Musa $\times$ sapientum & Malaysia & Williams \& Liu (1976) \\
\hline & Musa cavendishii & Taiwan & Yen (1972), Photita et al. (2002) \\
\hline & Musa acuminata & Indonesia & Wong et al. (2012), Wulandari et al. (2013) \\
\hline & Musa sp. & $\begin{array}{l}\text { Australia, Fiji, Indonesia, } \\
\text { Malaysia, Palau, Papua } \\
\text { New Guinea, Philippines, } \\
\text { Samoa, Solomon Islands }\end{array}$ & Wong et al. (2012, 2013), Wulandari et al. (2013), Hyde et al. (2014) \\
\hline P. mangiferae & Mangifera indica & Tanzania & Ebbels \& Allen (1979) \\
\hline
\end{tabular}


Supplementary Table 1 Continued.

\begin{tabular}{|c|c|c|c|}
\hline Species record & Host & Locality & References \\
\hline $\begin{array}{l}\text { P. mangifera- } \\
\text { indica }\end{array}$ & Mangifera indica & Thailand & Wikee et al. (2013b) \\
\hline P. musaechinensis & Musa sp. & China & Wu et al. (2014) \\
\hline \multirow[t]{25}{*}{ P. musarum } & Camellia oleifera & China & Yu et al. (2018) \\
\hline & Lycopersicon esculentum & India & Mathur (1979) \\
\hline & Musa acuminata & Hawaii & Raabe et al. (1981) \\
\hline & Musa basjoo & China & Tai (1979) \\
\hline & Musa cavendishii & Taiwan & Anonymous (1979) \\
\hline & Musa nana & Hawaii & Anonymous (1960) \\
\hline & Musa sapientum & Thailand & Giatgong (1980) \\
\hline & Musa sp. & India, New Caledonia & Mathur (1979), Huguenin (1966) \\
\hline & Musa textilis & Philippines & Reinking $(1918,1919)$ \\
\hline & Musa $\times$ paradisiaca & $\begin{array}{l}\text { Dominican Republic, } \\
\text { Hawaii, India }\end{array}$ & Ciferri (1929), Anonymous (1960), Mathur (1979), Kamal (2010) \\
\hline & $\begin{array}{l}\text { Musa } \times \text { paradisiaca var. } \\
\text { sapientum }\end{array}$ & China & Tai (1979) \\
\hline & Musa $\times$ sapientum & $\begin{array}{l}\text { India, Japan, Mexico, New } \\
\text { Caledonia, Philippines, } \\
\text { Taiwan }\end{array}$ & $\begin{array}{l}\text { Mathur (1979), Kobayashi (2007), Alvarez (1976), Huguenin (1966), } \\
\text { Reinking (1918, 1919), Anonymous (1979) }\end{array}$ \\
\hline & $\begin{array}{l}\text { Musa } \times \text { sapientum var. } \\
\text { paradisiaca }\end{array}$ & Dominican Republic & Ciferri (1961) \\
\hline & Erythrina variegata & Guam & Lenne (1990), Boa \& Lenné (1994) \\
\hline & Musa acuminata & Hawaii & Raabe et al. (1981) \\
\hline & Musa sp. & France, Hawaii & Photita et al. (2002), Stevens (1925) \\
\hline & Musa $\times$ sapientum & Dominican Republic & Ciferri (1929) \\
\hline & Prosopis pallida & Hawaii & Raabe et al. (1981) \\
\hline & Musa nana & China & Zhuang (2001) \\
\hline & Musa paradisiaca & India, Thailand & Wong et al. (2012) \\
\hline & Musa sp. & $\begin{array}{l}\text { Australia, Brunei } \\
\text { Darussalam, China, India, } \\
\text { Malaysia, Myanmar, } \\
\text { Nepal, Sri Lanka, Thailand }\end{array}$ & Wulandari et al. (2010), Wong et al. (2013), Thaung (2008b) \\
\hline & Musa $\times$ paradisiaca & India & Ali \& Saikia (1997) \\
\hline & Musa $\times$ sapientum & Brunei Darussalam & Peregrine \& Ahmad (1982) \\
\hline & Musa $\times$ paradisiaca & Dominican Republic & Ciferri (1961) \\
\hline & Musa acuminata & Hawaii & Teodoro (1937) \\
\hline
\end{tabular}


Supplementary Table 1 Continued.

\begin{tabular}{|c|c|c|c|}
\hline Species record & Host & Locality & References \\
\hline & Musa sp. & Hawaii & Meredith (1969) \\
\hline & Musa $\times$ sapientum & Fiji, Malaysia, Philippines & $\begin{array}{l}\text { Firman (1972), Johnston (1960), Williams \& Liu (1976), Turner (1971), van } \\
\text { der Aa (1973), Petrak \& Sydow (1931), Teodoro (1937) }\end{array}$ \\
\hline & Musa humilis & Philippines & Teodoro (1937) \\
\hline & Musa sp. & Philippines & Teodoro (1937) \\
\hline & Musa textilis & Philippines & Teodoro (1937) \\
\hline & Musa $\times$ paradisiaca & India, Philippines & Teodoro (1937) \\
\hline & Musa $\times$ sapientum & Philippines & Teodoro (1937) \\
\hline & $\begin{array}{l}\text { Musa } \times \text { sapientum var. } \\
\text { cinerea }\end{array}$ & Philippines & Teodoro (1937) \\
\hline & $\begin{array}{l}\text { Musa } \times \text { sapientum var. } \\
\text { compressa }\end{array}$ & Philippines & Teodoro (1937) \\
\hline & $\begin{array}{l}\text { Musa } \times \text { sapientum var. } \\
\text { lacatan }\end{array}$ & Philippines & Teodoro (1937) \\
\hline \multirow{12}{*}{$\begin{array}{l}P . \\
\text { paracapitalensis }\end{array}$} & Citrus aurantifolia & New Zealand & Guarnaccia et al. (2017) \\
\hline & Citrus aurantiifolia & New Zealand & Tran et al. (2019) \\
\hline & Citrus aurantium & Australia & Tran et al. (2019) \\
\hline & Citrus australasica & Australia & Tran et al. (2019) \\
\hline & Citrus floridana & Italy & Guarnaccia et al. (2017), Tran et al. (2019) \\
\hline & Citrus hystrix & Australia & Tran et al. (2019) \\
\hline & Citrus japonica & Australia & Tran et al. (2019) \\
\hline & Citrus limon & Spain & Guarnaccia et al. (2017), Tran et al. (2019) \\
\hline & Citrus maxima & Australia & Tran et al. (2019) \\
\hline & Citrus maxima-reticulata & Australia & Tran et al. (2019) \\
\hline & Citrus reticulata & Australia & Tran et al. (2019) \\
\hline & Citrus wintersii & Australia & Tran et al. (2019) \\
\hline \multirow{6}{*}{$\begin{array}{l}\text { P. parthenocissi } \\
P . \\
\text { partricuspidatae } \\
\text { P. philoprina }\end{array}$} & Parthenocissus quinquefolia & Missouri, United States & Zhang et al. (2013b), Zhou et al. (2015), Hyde et al. (2014) \\
\hline & Parthenocissus tricuspidata & Japan & Zhou et al. (2015) \\
\hline & Ilex aquifolium & $\begin{array}{l}\text { California, New Jersey, } \\
\text { Washington }\end{array}$ & Shaw (1973), Anonymous (1960) \\
\hline & Ilex coriacea & Florida & Alfieri Jr. et al. (1984), Anonymous (1960) \\
\hline & Ilex cornuta & North Carolina & Grand (1985) \\
\hline & Ilex crenata & North Carolina & Grand (1985) \\
\hline
\end{tabular}


Supplementary Table 1 Continued.

\begin{tabular}{|c|c|c|c|}
\hline Species record & Host & Locality & References \\
\hline & Ilex ораса & $\begin{array}{l}\text { North Carolina, New } \\
\text { Jersey, New York, South } \\
\text { Carolina, Texas, West } \\
\text { Virginia }\end{array}$ & Anonymous (1960), Grand (1985) \\
\hline & Ilex sp. & $\begin{array}{l}\text { Asia, Europe, Florida, } \\
\text { North America, United } \\
\text { Kingdom }\end{array}$ & Alfieri Jr. et al. (1984), von Arx \& Muelle (1954), Cannon et al. (1985) \\
\hline & Manihot glaziovii & India & Rao \& Mani Varghese (1988), Pande (2008) \\
\hline & Yucca sp. & Illinois & Cooke (1969) \\
\hline & Rhododendron catawbiense & Canada & Ginns (1986) \\
\hline & Rhododendron sp. & $\begin{array}{l}\text { California, Canada, Nova } \\
\text { Scotia, Ontario, } \\
\text { Massachusetts, North } \\
\text { Carolina, New Hampshire, } \\
\text { New York, United } \\
\text { Kingdom }\end{array}$ & $\begin{array}{l}\text { Barr (1970), Pirozynski (1974), Ginns (1986), Grand (1985), Cannon et al. } \\
\text { (1985) }\end{array}$ \\
\hline & Ilex aquifolium & California & French (1989) \\
\hline & Macrophoma ilicella & Georgia & Dzhalagonia (1965) \\
\hline & Cryptomeria japonica & Netherlands & Sultan et al. (2011) \\
\hline & Hedera helix & Switzerland & Luginbuehl \& Mueller (1980) \\
\hline & Ilex aquifolium & Switzerland & Luginbuehl \& Mueller (1980) \\
\hline & Ilex cinerea & Hong Kong & Lu et al. (2000), Zhuang (2001) \\
\hline & Ilex paraguariensis & Brazil & Takeda et al. (2003) \\
\hline & Juniperus communis & Switzerland & Luginbuehl \& Mueller (1980) \\
\hline & Taxus baccata & $\begin{array}{l}\text { Germany, Netherlands, } \\
\text { Poland, United States }\end{array}$ & $\begin{array}{l}\text { Slippers et al. (2004), Phillips et al. (2005), Phillips \& Alves (2009), Begoude } \\
\text { et al. (2010), McDonald \& Eskalen (2011), Lynch et al. (2013), Adesemoye et } \\
\text { al. (2014), Chen et al. (2014), Zhou et al. (2015), Nogueira et al. (2016), Hyde } \\
\text { et al. (2014), Mulenko et al. (2008), Sultan et al. (2011), Nouri et al. (2018) }\end{array}$ \\
\hline & Taxus baccata var. fastigiata & Poland & Mulenko et al. (2008) \\
\hline & Taxus cuspidata & Poland & Mulenko et al. (2008) \\
\hline & Rhododendron carolinianum & $\begin{array}{l}\text { Connecticut, North } \\
\text { Carolina, New Jersey, New } \\
\text { York }\end{array}$ & Anonymous (1960) \\
\hline & Rhododendron catawbiense & $\begin{array}{l}\text { Connecticut, } \\
\text { Massachusetts, Maryland, } \\
\text { New Jersey, New York, }\end{array}$ & Anonymous (1960) \\
\hline
\end{tabular}


Supplementary Table 1 Continued.

\begin{tabular}{|c|c|c|c|}
\hline Species record & Host & Locality & References \\
\hline & Rhododendron macrophyllum & $\begin{array}{l}\text { Pennsylvania, Virginia } \\
\text { New Jersey, Oregon, } \\
\text { Washington }\end{array}$ & Anonymous (1960), Shaw (1973) \\
\hline & Rhododendron maximum & $\begin{array}{l}\text { Connecticut, } \\
\text { Massachusetts, Maryland, } \\
\text { New Jersey, New York, } \\
\text { Pennsylvania, Virginia }\end{array}$ & Anonymous (1960) \\
\hline & Rhododendron sp. & $\begin{array}{l}\text { California, Connecticut, } \\
\text { Florida, Massachusetts, } \\
\text { Maryland, Netherlands, } \\
\text { New Zealand, New Jersey, } \\
\text { New York, Pennsylvania, } \\
\text { Virginia, Washington }\end{array}$ & $\begin{array}{l}\text { Anonymous (1931-1970, 1960), Alfieri Jr. et al. (1984), Wikee et al. (2013b), } \\
\text { Pennycook (1989), Eglitis et al. (1966) }\end{array}$ \\
\hline & Rhododendron $\times$ hybridum & Netherlands & BPI n/a.) \\
\hline & Chamaecyparis obtusa & Japan & Kobayashi (2007) \\
\hline & Cryptomeria japonica & Japan & $\begin{array}{l}\text { Kobayashi \& Sasaki (1975), Sivanesan (1984), Kobayashi (2007), Motohashi } \\
\text { et al. (2009) }\end{array}$ \\
\hline & Larix leptolepis & Japan & Kobayashi (2007) \\
\hline & Ilex aquifolium & $\begin{array}{l}\text { Germany, Netherlands, } \\
\text { Spain }\end{array}$ & Wikee et al. (2013b), Zhou et al. (2015), Hyde et al. (2014), Zhu et al. (2018) \\
\hline & Ilex latifolia & China & Tai (1979), Chen (2002), Teng (1996) \\
\hline & Ilex cornuta & China & Tai (1979), Teng (1996) \\
\hline & Ilex crenata & New Jersey & Anonymous (1960) \\
\hline & Ilex crenata cv. Rotundifolia & Georgia & Driver (1952) \\
\hline & Ilex opaca & $\begin{array}{l}\text { North Carolina, New } \\
\text { Jersey, New York, South } \\
\text { Carolina, Texas, West } \\
\text { Virginia }\end{array}$ & Anonymous (1960), Williams \& Hayne (1982) \\
\hline & Ilex sp. & $\begin{array}{l}\text { California, United } \\
\text { Kingdom }\end{array}$ & Anonymous (1960), Cannon et al. (1985) \\
\hline & Ilex verticillata & New York & Anonymous (1960) \\
\hline & Hedera helix & Portugal & Unamuno (1941) \\
\hline & Ilex aquifolium & Portugal & Unamuno (1941) \\
\hline & Rhododendron sp. & England & Davis (1946) \\
\hline & Rhododendron sp. & Austria & von Hoehnel (1931) \\
\hline P. rhizophorae & Cordyline fruticosa & Thailand & In this study \\
\hline
\end{tabular}


Supplementary Table 1 Continued.

\begin{tabular}{|c|c|c|c|}
\hline Species record & Host & Locality & References \\
\hline & Heliconia sp. & Thailand & In this study \\
\hline & Ixora chinensis & Thailand & In this study \\
\hline & Musa paradisiaca & Thailand & In this study \\
\hline & Punica granatum & Thailand & In this study \\
\hline & Rhizophora stylosa & Thailand & In this study \\
\hline P. schimae & Schima superba & China & Su \& Cai (2012), Zhou et al. (2015), Hyde et al. (2014) \\
\hline P. schimicola & Schima superba & China & Zhou et al. (2015) \\
\hline P. styracicola & Styrax grandiflorus & China, France & Zhang et al. (2013a), Wikee (2013b), Zhou et al. (2015), Hyde et al. (2014) \\
\hline $\begin{array}{l}P . \text { vitis- } \\
\text { rotundifoliae }\end{array}$ & Vitis rotundifolia & United States & Zhou et al. (2015) \\
\hline \multicolumn{4}{|c|}{ P. cruenta species complex } \\
\hline \multirow[t]{2}{*}{ P. abieticola } & Abies concolor & Canada & Hyde et al. (2014) \\
\hline & Aloe ferox & South Africa & Wikee et al. (2013b), Zhou et al. (2015) \\
\hline \multirow[t]{19}{*}{ P. cornicola } & Cornus alternifolia & US, Wisconsin & Anonymous (1960) \\
\hline & Cornus asperifolia & US & Anonymous (1960) \\
\hline & Cornus florida & $\begin{array}{l}\text { Australia, Florida, North } \\
\text { Carolina, United States }\end{array}$ & $\begin{array}{l}\text { Sampson \& Walker (1982), Grand (1985), Grand et al. (1975), Wikee et al. } \\
\text { (2013b), Zhou et al. (2015), Hyde et al. (2014) }\end{array}$ \\
\hline & Cornus hemsleyi & Armenia & Simonyan (1981) \\
\hline & Cornus mas & Ukraine & Dudka et al. (2004) \\
\hline & Cornus occidentalis & US & Anonymous (1960) \\
\hline & Cornus racemosa & US & Anonymous (1960) \\
\hline & Cornus sp. & US & Anonymous (1960) \\
\hline & Cornus stolonifera & US & Anonymous (1960) \\
\hline & Cornus alba & $\begin{array}{l}\text { Canada, Iowa, Ohio, } \\
\text { Poland }\end{array}$ & Conners (1967), Gilman \& Archer (1929), Farr (1991), Mulenko et al. (2008) \\
\hline & Cornus alternifolia & Canada, Iowa, US & Conners (1967), Gilman \& Archer (1929), Anonymous (1960) \\
\hline & Cornus amomum & Iowa, Missouri & Farr (1991), Gilman \& Archer (1929), Maneval (1937) \\
\hline & Cornus asperifolia & $\begin{array}{l}\text { Iowa, Kansas, Oklahoma, } \\
\text { Range of host }\end{array}$ & $\begin{array}{l}\text { Gilman \& Archer (1929), Rogerson (1953), Preston (1945), Anonymous } \\
\text { (1960) }\end{array}$ \\
\hline & Cornus australis & Iran & Jorstad (1960) \\
\hline & Cornus californica & California, Canada & French (1989), Ginns (1986) \\
\hline & Cornus canadensis & Canada & Ginns (1986) \\
\hline & Cornus controversa & Japan & Kobayashi (2007) \\
\hline & Cornus coreana & China & Bai (2003) \\
\hline & Cornus florida & $\begin{array}{l}\text { Eastern states, Florida, } \\
\text { Georgia, Iowa, Missouri, }\end{array}$ & $\begin{array}{l}\text { Anonymous (1960), Alfieri et al. (1984), Miller et al. (1954), Anonymous } \\
\text { (1960), Maneval (1937), Grand (1985), Preston (1947) }\end{array}$ \\
\hline
\end{tabular}


Supplementary Table 1 Continued.

\begin{tabular}{|c|c|c|c|}
\hline Species record & Host & Locality & References \\
\hline & & North Carolina, Oklahoma & \\
\hline & Cornus hemsleyi & China & Bai (2003) \\
\hline & Cornus mas & $\begin{array}{l}\text { Bulgaria, Greece, Poland, } \\
\text { Ukraine }\end{array}$ & $\begin{array}{l}\text { Vanev et al. (1997), Pantidou (1973), Mulenko et al. (2008), Dudka et al. } \\
\text { (2004) }\end{array}$ \\
\hline & Cornus nuttallii & Canada & Ginns (1986) \\
\hline & Cornus occidentalis & US & Anonymous (1960) \\
\hline & Cornus paniculata & Iowa & Gilman \& Archer (1929) \\
\hline & Cornus racemosa & $\begin{array}{l}\text { Canada, Iowa, Kansas, } \\
\text { New York, Oklahoma, } \\
\text { Range of host, Virginia, } \\
\text { Wisconsin }\end{array}$ & Farr (1991), Mix (1954), Preston (1947), Anonymous (1960) \\
\hline & Cornus sanguinea & $\begin{array}{l}\text { Austria, Bulgaria, } \\
\text { Czechoslovakia, England, } \\
\text { France, Germany, Iran, } \\
\text { Italy, Poland, Portugal, } \\
\text { Romania, Sweden, United } \\
\text { States, USSR }\end{array}$ & $\begin{array}{l}\text { Farr (1991), Vanev et al. (1997), Arzanlou \& Torbati (2013), Mulenko et al. } \\
\text { (2008), de Sousa Dias et al. (1987), Ge et al. (2016) }\end{array}$ \\
\hline & $\begin{array}{l}\text { Cornus sanguinea subsp. } \\
\text { australis }\end{array}$ & Bulgaria, Iran & Vanev et al. (1997), Arzanlou \& Torbati (2013) \\
\hline & Cornus sericea & $\begin{array}{l}\text { Canada, Italy, Missouri, } \\
\text { Poland }\end{array}$ & Ginns (1986), Garibaldi et al. (2003), Maneval (1937), Mulenko et al. (2008) \\
\hline & Cornus sp. & $\begin{array}{l}\text { Bulgaria, China, Georgia, } \\
\text { Germany, Iowa, } \\
\text { Mississippi, Netherlands, } \\
\text { US }\end{array}$ & $\begin{array}{l}\text { Bobev (2009), Tai (1979), Chen (2002), Zhuang (2005), Guo (1997), } \\
\text { Dzhalagonia (1965), Farr (1991), Gilman \& Arche (1929), Parris (1959), Ge } \\
\text { et al. (2016), Anonymous (1960) }\end{array}$ \\
\hline & Cornus stolonifera & $\begin{array}{l}\text { Canada, Canada, Quebec, } \\
\text { Iowa, Montana, North } \\
\text { Dakota, Oklahoma, Range } \\
\text { of host, South Dakota, } \\
\text { Washington, Wisconsin }\end{array}$ & $\begin{array}{l}\text { Conners (1967), Parmelee (1988), Feau et al. (2005), Gilman \& Archer } \\
\text { (1929), Shaw (1973), Brenckle (1918), Preston (1945), Anonymous (1960), } \\
\text { Mankin (1969), Greene (1942) }\end{array}$ \\
\hline & Cornus stolonifera var. aurea & Iowa & Gilman \& Archer (1929) \\
\hline & Cornus stolonifera var. lutea & Iowa & Gilman \& Archer (1929) \\
\hline & Cornus walteri & China & Zhuang (2005) \\
\hline & Swida australis & Ukraine & Dudka et al. (2004) \\
\hline & $\begin{array}{l}\text { Swida sanguinea subsp. } \\
\text { australis }\end{array}$ & Armenia & Simonyan (1981) \\
\hline
\end{tabular}


Supplementary Table 1 Continued.

\begin{tabular}{|c|c|c|c|}
\hline Species record & Host & Locality & References \\
\hline \multirow{31}{*}{ P. cruenta } & Cornus obliqua & Wisconsin & Greene (1962) \\
\hline & Cornus racemosa & Wisconsin & Greene (1962) \\
\hline & Cornus rugosa & Wisconsin & Greene (1962) \\
\hline & Cornus sanguinea & Maryland, Netherlands & Verkley et al. (2013) \\
\hline & Maianthemum bifolium & Poland & Mulenko et al. (2008) \\
\hline & Polygonatum nakaiana & China & Tai (1979) \\
\hline & $\begin{array}{l}\text { Polygonatum odoratum var. } \\
\text { pluriflorum }\end{array}$ & China & Tai (1979) \\
\hline & Polygonatum & Austria & Petrak (1963) \\
\hline & Lomatium suksdorfii & Washington & Shaw (1973) \\
\hline & Convallaria majalis & Poland & Adamska (2001) \\
\hline & Maianthemum bifolium & Poland & Adamska (2001) \\
\hline & Polygonatum multiflorum & Poland & Adamska (2001) \\
\hline & Polygonatum sp. & Sweden, Ukraine & Dudka et al. (2004), Eriksson (2014) \\
\hline & Disporum viridescens & China & Tai (1979) \\
\hline & Polygonatum humile & China & Tai (1979) \\
\hline & $\begin{array}{l}\text { Polygonatum odoratum var. } \\
\text { pluriflorum }\end{array}$ & China & Tai (1979) \\
\hline & Polygonatum officinale & China & Tai (1979) \\
\hline & Smilacina japonica & China & Tai (1979) \\
\hline & Tovara japonica & China & Tai (1979) \\
\hline & Bambuseae & Dominican Republic & Ciferri (1961) \\
\hline & Convallaria majalis & $\begin{array}{l}\text { Lithuania, Poland, Russia, } \\
\text { Scotland }\end{array}$ & $\begin{array}{l}\text { Treigiene (2006), Mulenko et al. (2008), Ruszkiewicz-Michalska et al. } \\
\text { (2012), Gasich et al. (1999), Foister (1961) }\end{array}$ \\
\hline & Iris sp. & Illinois & Boewe (1964) \\
\hline & Maianthemum bifolium & Poland & Mulenko et al. (2008) \\
\hline & Oakesia sp. & Wisconsin & Greene (1949) \\
\hline & Polygonatum biflorum & United States & Anonymous (1960) \\
\hline & Polygonatum commutatum & Missouri & Maneval (1937) \\
\hline & Polygonatum lasianthum & China & Tai (1979) \\
\hline & Polygonatum latifolium & USSR & van der Aa (1973) \\
\hline & Polygonatum macropodum & China & Bai (2000) \\
\hline & Polygonatum multiflorum & $\begin{array}{l}\text { India, Lithuania, Poland, } \\
\text { Romania, Ukraine }\end{array}$ & $\begin{array}{l}\text { van der Aa (1973), Treigiene (2006), Mulenko et al. (2008), Wulandari et al. } \\
\text { (2013), Dudka et al. (2004) }\end{array}$ \\
\hline & Polygonatum odoratum & $\begin{array}{l}\text { Lithuania, Poland, } \\
\text { Romania, Ukraine }\end{array}$ & $\begin{array}{l}\text { Treigiene (2006), Mulenko et al. (2008), van der Aa (1973), Dudka et al. } \\
\text { (2004) }\end{array}$ \\
\hline
\end{tabular}


Supplementary Table 1 Continued.

\begin{tabular}{|c|c|c|c|}
\hline Species record & Host & Locality & References \\
\hline & $\begin{array}{l}\text { Polygonatum odoratum var. } \\
\text { pluriflorum }\end{array}$ & China, Japan & Jin (2011), Motohashi et al. (2009) \\
\hline & Polygonatum officinale & Austria, China & van der Аa (1973), Tai (1979) \\
\hline & Polygonatum orientale & Ukraine & Dudka et al. (2004) \\
\hline & Polygonatum sewerzowii & Uzbekistan & Gafforov (2017) \\
\hline & Polygonatum sibiricum & China & Tai (1979) \\
\hline & Polygonatum sp. & China, India, Wisconsin & Teng (1996), Mathu (1979), Greene (1949) \\
\hline & Polygonatum vulgare & Spain & Gonzalez Fragoso (1917) \\
\hline & Smilacina amplexicaulis & New Mexico, United States & Anderson (1919), Anonymous (1960) \\
\hline & Smilacina racemosa & Missouri, United States & Maneval (1937), Anonymous (1960) \\
\hline & Smilacina stellata & $\begin{array}{l}\text { North Dakota, United } \\
\text { States }\end{array}$ & Anderson (1919), Brenckle (1918), Anonymous (1960) \\
\hline & Smilax china & Japan & Kobayashi (2007) \\
\hline & Smilax herbacea & China & Tai (1979) \\
\hline & Smilax hispida & Missouri & Maneval (1937) \\
\hline & Smilax sp. & Missouri & Maneval (1937) \\
\hline & Uvularia sp. & Wisconsin & Greene (1949) \\
\hline & Maianthemum dilatatum & Washington & Shaw (1973) \\
\hline & Polygonatum multiflorum & Pakistan & Ahmad (1969), Ahmad et al. (1997) \\
\hline & Smilacina racemosa & Idaho, Washington & Shaw (1973) \\
\hline & Smilacina stellata & $\begin{array}{l}\text { Idaho, Montana, Oregon, } \\
\text { Washington }\end{array}$ & Shaw (1973) \\
\hline & Maianthemum dilatatum & Alaska, Washington, & Anonymous (1960) \\
\hline & Polygonatum biflorum & $\begin{array}{l}\text { Connecticut, Indiana, New } \\
\text { York, Virginia, Wisconsin, }\end{array}$ & Anonymous (1960) \\
\hline & Polygonatum canaliculatum & Iowa, Ohio, Wisconsin & Anonymous (1960) \\
\hline & Polygonatum commutatum & Iowa & Gilman \& Archer (1929) \\
\hline & Polygonum multiflorum & Greece & Pantidou (1973) \\
\hline & Smilacina amplexicaulis & California, New Mexico & Anonymous (1960) \\
\hline & Smilacina racemosa & $\begin{array}{l}\text { Iowa, Illinois, Oklahoma, } \\
\text { Range of host }\end{array}$ & Gilman \& Archer (1929), Neely (1959), Preston (1947), Anonymous (1960) \\
\hline & Smilacina stellata & Mississippi, Range of host & Parris (1959), Anonymous (1960) \\
\hline & Smilax herbacea & Iowa & Anonymous (1960), Gilman \& Archer (1929) \\
\hline & Smilax hispida & Iowa & Gilman \& Archer (1929) \\
\hline & Smilax rotundifolia & Iowa & Anonymous (1960), Gilman \& Archer (1929) \\
\hline & Smilax tamnoides var. hispida & Iowa & Anonymous (1960) \\
\hline
\end{tabular}


Supplementary Table 1 Continued.

\begin{tabular}{|c|c|c|c|}
\hline Species record & Host & Locality & References \\
\hline & Uvularia grandiflora & $\begin{array}{l}\text { Iowa, Illinois, Missouri, } \\
\text { Virginia, Wisconsin }\end{array}$ & Anonymous (1960) \\
\hline & Uvularia perfoliata & Indiana & Anonymous (1960) \\
\hline & Uvularia sessilifolia & $\begin{array}{l}\text { Connecticut, New York, } \\
\text { Wisconsin }\end{array}$ & Anonymous (1960) \\
\hline & Polygonatum officinale & Portugal & Nag Raj (1993), Costa \& Camara (1952) \\
\hline \multirow[t]{2}{*}{ P. cryptomeriae } & Cryptomeria japonica & $\begin{array}{l}\text { District of Columbia, } \\
\text { Japan, Korea, Virginia }\end{array}$ & $\begin{array}{l}\text { Brittingham \& O’Brien (1978), Leuchtmann et al.1992), Shaw et al. (2006), } \\
\text { Motohashi et al. (2009), Cho \& Shin (2004) }\end{array}$ \\
\hline & Cunninghamia lanceolata & China & Chen (2002) \\
\hline \multirow[t]{7}{*}{ P. foliorum } & Rhododendron ponticum & Netherlands & Timmwemans (1957) \\
\hline & Taxus baccata & England, Europe & Dennis (1978), von Arx \& Mueller (1954) \\
\hline & Taxus sp. & United Kingdom & Cannon et al. (1985) \\
\hline & Yucca sp. & Mexico & Chacón \& Carrion (1984) \\
\hline & Cryptomeria japonica & United States & Wikee et al. (2013b) \\
\hline & Taxus baccata & Italy, Netherlands & $\begin{array}{l}\text { Wikee et al. (2013b), Zhou et al. (2015), Mayorquin et al. (2016), Hyde et al. } \\
\text { (2014) }\end{array}$ \\
\hline & Taxus baccata & Scotland & Spaulding (1961), Foister (1961) \\
\hline \multirow[t]{6}{*}{ P. gaultheriae } & Gaultheria humifusa & Netherlands, United States & Sultan et al. (2011), Zhou et al. (2015), Hyde et al. (2014) \\
\hline & Gaultheria cumingiana & Taiwan & Anonymous (1979) \\
\hline & Gaultheria humifusa & United States, Washington & Wikee et al. (2013b), van der Aa (1973) \\
\hline & Gaultheria procumbens & New Jersey, Range of host & $\begin{array}{l}\text { van der Aa (1973), Ellis \& Everhart (1878-1898), Nag Raj (1993), Cash } \\
\text { (1953), Anonymous (1960) }\end{array}$ \\
\hline & Gaultheria shallon & $\begin{array}{l}\text { California, Canada, } \\
\text { Oregon, Washington }\end{array}$ & $\begin{array}{l}\text { Eglitis et al. (1966), Ginns (1986), Shaw (1973), Lambe (1960), Anonymous } \\
\text { (1960) }\end{array}$ \\
\hline & Gaultheria spp. & North America & $\begin{array}{l}\text { Bissett \& Darbyshir (1984a), Wulandari et al. (2013), van der Aa (1973), Van } \\
\text { Der \& Vanev (2002) }\end{array}$ \\
\hline P. hakeicola & Hakea sp. & Australia & Crous et al. (2018) \\
\hline \multirow[t]{5}{*}{ P. hamamelidis } & Hamamelis sp. & United States & Anonymous (1960) \\
\hline & Hamamelis japonica & Japan & $\begin{array}{l}\text { Kobayashi (2007), Motohashi et al. (2009), Wikee et al. (2013b), Zhou et al. } \\
\text { (2015), Hyde et al. (2014) }\end{array}$ \\
\hline & $\begin{array}{l}\text { Hamamelis japonica subsp. } \\
\text { megalophylla }\end{array}$ & Japan & Motohashi et al. (2009) \\
\hline & $\begin{array}{l}\text { Hamamelis japonica var. } \\
\text { discolor f. obtusata }\end{array}$ & Japan & Motohashi et al. (2009) \\
\hline & Hamamelis sp. & $\begin{array}{l}\text { Eastern states, Mississippi, } \\
\text { Tennessee, Wisconsin }\end{array}$ & Anonymous (1960) \\
\hline
\end{tabular}


Supplementary Table 1 Continued.

\begin{tabular}{|c|c|c|c|}
\hline Species record & Host & Locality & References \\
\hline & Hamamelis virginiana & $\begin{array}{l}\text { Canada, Canada, Ontario, } \\
\text { North Carolina, South } \\
\text { Carolina }\end{array}$ & $\begin{array}{l}\text { Ginns (1986), Bissett \& Darbyshir (1984b), van der Aa (1973), Nag Raj } \\
\text { (1993) }\end{array}$ \\
\hline P. hubeiensis & Viburnum odoratissimum & China & $\begin{array}{l}\text { Hyde et al. (2014), Wikee et al. (2013b), Wulandari et al. (2013), Zhang et al. } \\
\text { (2013a), Zhou et al. (2015) }\end{array}$ \\
\hline P. illicii & Illicium verum & China & Lin et al. (2017) \\
\hline P. leucothoicola & Leucothoe catesbaei & Japan & Hyde et al. (2014), Wikee et al. (2013b), Zhou et al. (2015) \\
\hline P. ligustricola & Ligustrum obtusifolium & Japan & Hyde et al. (2014), Motohashi et al. (2009), Zhou et al. (2015) \\
\hline \multirow[t]{17}{*}{ P. minima } & Acer rubrum & $\begin{array}{l}\text { Louisiana, Mississippi, } \\
\text { North Carolina }\end{array}$ & Overholts (1938), Parris (1959), Wolf et al. (1938) \\
\hline & Acer saccharophorum & Mississippi & Parris (1959) \\
\hline & Acer sp. & $\begin{array}{l}\text { Alabama, Florida, New } \\
\text { Jersey }\end{array}$ & Blain (1931), Alfieri Jr. et al. (1984), Nag Raj (1993), Cash (1953) \\
\hline & Acer cinnamomifolium & China & Zhuang (2001), Bai (2000) \\
\hline & Acer negundo & Alabama, China & Anderson (1919), Tai (1979), Chen (2002), Bai (2000) \\
\hline & Acer campestre & Canada, Ontario, Ukraine & Bissett \& Darbyshire (1984c), Dudka et al. (2004) \\
\hline & Acer crataegifolium & Japan & Motohashi et al. (2009) \\
\hline & Acer ginnala & Canada, Manitoba, Ontario & Ginns (1986), Bissett \& Darbyshire (1984c) \\
\hline & Acer glabrum & Idaho, Missouri & Anonymous (1960) \\
\hline & Acer mono & China & Tai (1979), Chen (2002), Zhuang (2005) \\
\hline & Acer negundo & $\begin{array}{l}\text { Missouri, North Carolina, } \\
\text { Range of host }\end{array}$ & Maneval (1937), Grand (1985), Anonymous (1960) \\
\hline & Acer nigrum & United States & Anonymous (1960) \\
\hline & Acer palmatum & $\begin{array}{l}\text { Connecticut, North } \\
\text { Carolina }\end{array}$ & Anonymous (1960), Grand (1985) \\
\hline & Acer platanoides & $\begin{array}{l}\text { Canada, Eastern states, } \\
\text { Missouri, North Carolina, } \\
\text { Wisconsin }\end{array}$ & $\begin{array}{l}\text { Conners (1967), Anonymous (1960), Maneval (1937), Grand (1985), Greene } \\
\text { (1958) }\end{array}$ \\
\hline & Acer pseudoplatanus & Connecticut, Pennsylvania & Anonymous (1960) \\
\hline & Acer pycnanthum & Japan & Motohashi et al. (2009) \\
\hline & Acer rubrum & $\begin{array}{l}\text { Canada, Canada, New } \\
\text { Brunswick, Canada, Nova } \\
\text { Scotia, Canada, Ontario, } \\
\text { Canada, Prince Edward } \\
\text { Island, Canada, Quebec, } \\
\text { Florida, Massachusetts, } \\
\end{array}$ & $\begin{array}{l}\text { Conners, (1967), Ginns (1986), Bissett \& Darbyshire (1984c), Miller (1991), } \\
\text { Schubert (1991), Cooke (1978), Parris (1959), Grand (1985), Grand et al. } \\
\text { (1975), Wikee et al. (2013b), van der Aa (1973), Mix (1954), Preston (1945), } \\
\text { Fergus (1954), Anonymous (1960), Mankin (1969), Zhou et al. (2015), Hyde } \\
\text { et al. (2014), Greene (1966) }\end{array}$ \\
\hline
\end{tabular}


Supplementary Table 1 Continued.

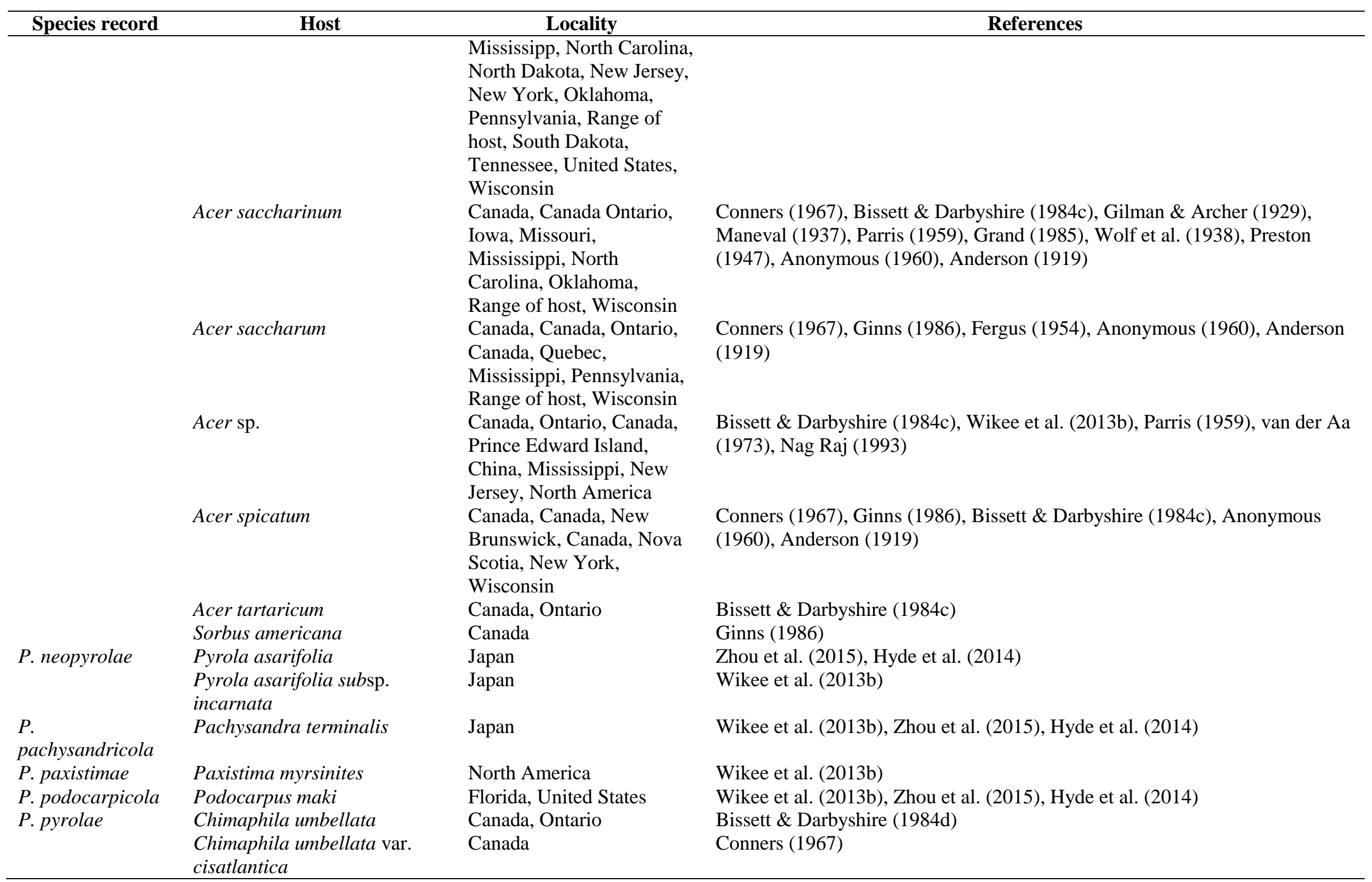


Supplementary Table 1 Continued.

\begin{tabular}{|c|c|c|c|}
\hline Species record & Host & Locality & References \\
\hline & Erica carnea & Japan & Sultan et al. (2011) \\
\hline & Gaultheria shallon & Canada, British Columbia & Leuchtmann et al. (1992) \\
\hline & Orthilia secunda & Poland & Mulenko et al. (2008) \\
\hline & Pyrola asarifolia & $\begin{array}{l}\text { Canada, New Brunswick, } \\
\text { Montana, Oregon }\end{array}$ & Bissett \& Darbyshire (1984d), Shaw (1973), Shaw et al. (2006) \\
\hline & $\begin{array}{l}\text { Pyrola asarifolia var. } \\
\text { purpurea }\end{array}$ & Alaska & Parmelee (1958) \\
\hline & Pyrola bracteata & Canada, British Columbia & Bissett \& Darbyshire (1984d) \\
\hline & Pyrola elliptica & Wisconsin & Anonymous (1960) \\
\hline & Pyrola rotundifolia & $\begin{array}{l}\text { Delaware, Lithuania, } \\
\text { Ukraine, United States }\end{array}$ & $\begin{array}{l}\text { van der Aa (1973), Ellis \& Everhart (1889), Nag Raj (1993), Cash (1953), } \\
\text { Treigiene (2006), Dudka et al. (2004), Wikee et al. (2013b) }\end{array}$ \\
\hline P. rubella & $\begin{array}{l}\text { Pyrola rotundifolia var. } \\
\text { americana }\end{array}$ & Delaware, Montana & Anonymous (1960) \\
\hline P. paviae & Pyrola sp. & United States & Sultan et al. (2011) \\
\hline P. telopeae & Vaccinium myrtillus & Lithuania & Treigiene (2006) \\
\hline \multicolumn{4}{|c|}{ P. vaccinii species complex } \\
\hline \multirow[t]{14}{*}{ P. vaccinii } & Gaultheria procumbens & Eastern states & Barr (1970) \\
\hline & Kalmia latifolia & Eastern states & Barr (1970) \\
\hline & Kalmia sp. & Rhode Island & Goos (2010) \\
\hline & Lyonia lucida & Eastern states & Barr (1970) \\
\hline & Vaccinium ashei & Florida & Alfieri Jr. et al. (1984) \\
\hline & Vaccinium elliottii & Florida & Alfieri Jr. et al. (1984) \\
\hline & Vaccinium macrocarpon & $\begin{array}{l}\text { Eastern states, } \\
\text { Massachusetts, New } \\
\text { Jersey, Washington, } \\
\text { Wisconsin }\end{array}$ & Barr (1970), Weidemann \& Boone (1983) \\
\hline & Vaccinium sp. & Rhode Island & Goos (2010) \\
\hline & Acer truncatum & China & Sun et al. (2011) \\
\hline & Arctostaphylos columbiana & British Columbia, Canada & Conners (1967) \\
\hline & Gaylussacia brachycera & Maryland & Anonymous (1960) \\
\hline & Kalmia latifolia & $\begin{array}{l}\text { Connecticut, New Jersey, } \\
\text { New York, Virginia }\end{array}$ & Anonymous (1960) \\
\hline & Oxycoccus macrocarpos & Netherlands & Sultan et al. (2011) \\
\hline & Oxycoccus macrocarpus & United States & $\begin{array}{l}\text { Wulandari et al. (2009), Wikee et al. (2013b), Zhou et al. (2015), Hyde et al. } \\
\text { (2014) }\end{array}$ \\
\hline
\end{tabular}


Supplementary Table 1 Continued.

\begin{tabular}{|c|c|c|c|}
\hline Species record & Host & Locality & References \\
\hline & Vaccinium macrocarpon & $\begin{array}{l}\text { New Jersey, Oregon, } \\
\text { Range of host, Washington }\end{array}$ & Shaw (1973), Eglitis et al. (1966), Anonymous (1960) \\
\hline & Vaccinium oxycoccos & United States & Anonymous (1960) \\
\hline & Pieris nitida & Mississippi & Tracy \& Earle (1895) \\
\hline & Vaccinium ovatum & California, Washington & $\begin{array}{l}\text { Anonymous (1960), French (1987), Nag Raj (1993), Bona (1928), Shaw } \\
\text { (1973), Eglitis et al. (1966) }\end{array}$ \\
\hline & Vaccinium arboreum & $\begin{array}{l}\text { Alabama, Florida, } \\
\text { Mississippi }\end{array}$ & $\begin{array}{l}\text { van der Aa (1973), Anonymous (1960), Weidemann et al. (1982), Nag Raj } \\
\text { (1993), Zhang et al. (2013b), Alfieri Jr. et al. (1984), Parris (1959) }\end{array}$ \\
\hline & Vaccinium ashei & Mississippi & Parris (1959) \\
\hline & Vaccinium corymbosum & Florida & Miller (1997) \\
\hline & Vaccinium macrocarpon & $\begin{array}{l}\text { Massachusetts, Michigan, } \\
\text { New Jersey, United States, } \\
\text { Wisconsin }\end{array}$ & $\begin{array}{l}\text { Weidemann \& Boone (1983), Zhang et al. (2013b), Polashock et al. (2009), } \\
\text { Olatinwo et al. (2003), Waller et al. (2020), Zhou et al. (2015), Hyde et al. } \\
\text { (2014), McManus (1998) }\end{array}$ \\
\hline & Vaccinium ovatum & California & French (1989) \\
\hline & Vaccinium sp. & China, North America & Wikee et al. (2013b) \\
\hline & Vaccinium vitis-idaea & China & Bai (2000) \\
\hline & Vaccinium ashei & $\begin{array}{l}\text { Georgia, Maryland, } \\
\text { Mississippi, North Carolina }\end{array}$ & Anonymous (1960) \\
\hline & Vaccinium corymbosum & $\begin{array}{l}\text { Georgia, Maryland, North } \\
\text { Carolina }\end{array}$ & Anonymous (1960) \\
\hline P. vacciniicola & Vaccinium macrocarpon & United States & Wikee et al. (2013b), Zhou et al. (2015), Hyde et al. (2014) \\
\hline \multicolumn{4}{|c|}{ P. rhodorae species complex } \\
\hline P. mimusopisicola & Mimusops zeyheri & South Africa & Crous et al. (2014) \\
\hline \multirow[t]{5}{*}{ P. rhodorae } & Rhododendron ponticum & United Kingdom & Dennis (1986) \\
\hline & Rhododendron sp. & $\begin{array}{l}\text { Denmark, England, } \\
\text { Scotland }\end{array}$ & Lind (1913), Anonymous (1928), Dennis \& Foister (1942), Foister (1961) \\
\hline & Rhododendron californicum & Oregon & Zeller (1934) \\
\hline & Rhododendron smirnowii & Washington & Eglitis et al. (1966) \\
\hline & Rhododendron sp. & England, Washington & Eglitis et al. (1966) \\
\hline \multicolumn{4}{|c|}{ P. concentrica species complex } \\
\hline P. aspidistricola & Aspidistra elatior & Japan & $\begin{array}{l}\text { Motohashi et al. (2008, 2009), Wikee et al. (2013b), Zhou et al. (2015), Hyde } \\
\text { et al. (2014) }\end{array}$ \\
\hline $\begin{array}{l}\text { P. aucubae- } \\
\text { japonicae }\end{array}$ & Аucuba japonica & Japan & Hernandez-Restrepo et al. (2016) \\
\hline P. bifrenariae & Bifrenaria harrisoniae & Brazil & Glienke et al. (2011) \\
\hline P. catimbauensis & Mandevilla catimbauensis & Brazil & Crous et al. (2017) \\
\hline
\end{tabular}


Supplementary Table 1 Continued.

\begin{tabular}{|c|c|c|c|}
\hline Species record & Host & Locality & References \\
\hline P. citriasiana & Citrus maxima & Thailand, China, Vietnam & Wulandari et al. (2009), Guarnaccia et al. (2017) \\
\hline \multirow[t]{2}{*}{ P. citribrasiliensis } & Citrus limon & Brazil & $\begin{array}{l}\text { Glienke et al. (2011), Wikee et al. (2011, 2013b), Zhou et al. (2015), Hyde et } \\
\text { al. (2014) }\end{array}$ \\
\hline & Citrus sp. & Brazil & $\begin{array}{l}\text { Glienke et al. (2011), Wikee et al. (2011, 2013a, b), Miles et al. (2013), } \\
\text { Wulandari et al. (2013), Guarnaccia et al. (2017), Tran et al. (2019) }\end{array}$ \\
\hline \multirow[t]{18}{*}{ P. citricarpa } & Aegle marmelos & Myanmar & Thaung (2008b) \\
\hline & Camellia sinensis & Papua New Guinea & Shaw (1984) \\
\hline & Cassia emarginata & Cuba & Urtiaga (1986) \\
\hline & Cedrela mexicana & Cuba & Urtiaga (1986) \\
\hline & Cedrela odorata & Cuba & Urtiaga (2004) \\
\hline & Chrysanthemum $\times$ morifolium & Hong Kong & Lu et al. (2000), Zhuang (2001) \\
\hline & Citrus $\times$ grandis-reticulata & New Zealand & Gadgil (2005) \\
\hline & Citrus $\times$ paradisi & $\begin{array}{l}\text { Australia, South Africa, } \\
\text { South Africa, KwaZulu- } \\
\text { Natal, South Africa, } \\
\text { Mpumalanga, Swaziland }\end{array}$ & $\begin{array}{l}\text { Simmonds (1966), Gorter (1977), Crous et al. (2000), Meyer et al. (2001, } \\
\text { 2006) }\end{array}$ \\
\hline & Citrus $\times$ tangelo & New Zealand & Pennycook (1989), Gadgil (2005) \\
\hline & Citrus aurantiacum & Brazil & Sultan et al. (2011) \\
\hline & Citrus aurantifolia & $\begin{array}{l}\text { Cook Islands, Fiji, Niue, } \\
\text { Samoa, Tonga }\end{array}$ & Dingley et al. (1981) \\
\hline & Citrus aurantium & $\begin{array}{l}\text { Australia, Brazil, China, } \\
\text { Myanmar }\end{array}$ & $\begin{array}{l}\text { Wulandari et al. (2009), Phillips et al. (2009), Minnis et al. (2012), Nouri et } \\
\text { al. (2018), Thaung (2008b), Tai (1979), Bai (2000), Nag Raj (1993), Glienke } \\
\text { et al. (2011), Wikee et al. (2011, 2013a, b), Ismail et al. (2012) }\end{array}$ \\
\hline & Citrus decumana & Myanmar & Thaung (2008b) \\
\hline & Citrus deliciosa & Australia, Brazil & Nag Raj (1993), Mendes (1998) \\
\hline & Citrus grandis & China & Tai (1979), Bai (2000) \\
\hline & Citrus junos & China & Tai (1979), Bai (2000) \\
\hline & Citrus limon & $\begin{array}{l}\text { Argentina, Australia, } \\
\text { Brazil, Cook Islands, Fiji, } \\
\text { Italy, Nigeria, Niue, } \\
\text { Samoa, South Africa, } \\
\text { South Africa, } \\
\text { Mpumalanga, Tonga, } \\
\text { Tunisia, Uruguay, } \\
\text { Zimbabwe }\end{array}$ & $\begin{array}{l}\text { Simmonds (1966), Wulandari et al. (2009), Dingley et al. (1981), Meyer et al. } \\
\text { (2001, 2006), Whiteside (1966), Wikee et al. (2011, 2013a, b), Guarnaccia et } \\
\text { al. (2017), Glienke et al. (2011), Miles et al. (2013), Zhou et al. (2015), Tran } \\
\text { et al. (2019), Hyde et al. (2014), Mendes et al. (1998), Boughalleb-M'Hamdi } \\
\text { et al. (2020) }\end{array}$ \\
\hline & Citrus limon & Australia & Simmonds (1966) \\
\hline
\end{tabular}


Supplementary Table 1 Continued.

\begin{tabular}{|c|c|c|c|}
\hline Species record & Host & Locality & References \\
\hline & Citrus limonia & $\begin{array}{l}\text { China, Southern Africa, } \\
\text { Australia, Brazil }\end{array}$ & $\begin{array}{l}\text { Gorter (1977), Crous et al. (2000), Tai (1979), Bai (2000), Doidge (1950), } \\
\text { Nag Raj (1993), Glienke et al. (2011) }\end{array}$ \\
\hline & Citrus maxima & $\begin{array}{l}\text { Southern Africa, } \\
\text { Philippines, Brazil }\end{array}$ & Reinking (1919, 1918, 1921), Doidge (1950), Glienke et al. (2011) \\
\hline & Citrus medica & Myanmar & Thaung (2008b) \\
\hline & Citrus medica var. limonum & Myanmar & Thaung (2008b) \\
\hline & Citrus microcarpa & China & Tai (1979), Bai (2000) \\
\hline & Citrus natsudaidai & Japan & Kobayashi (2007) \\
\hline & Citrus nobilis & China, Philippines & Teodoro (1937), Reinking (1921), Tai (1979), Zhuang (2001), Bai (2000) \\
\hline & Citrus nobilis var. deliciosa & Southern Africa & Doidge (1950) \\
\hline & Citrus paradisi & Cook Islands & Dingley et al. (1981) \\
\hline & Citrus reticulata & $\begin{array}{l}\text { Australia, Cook Islands, } \\
\text { Fiji, Hong Kong, Niue, } \\
\text { South Africa, South Africa, } \\
\text { Mpumalanga, Tonga }\end{array}$ & $\begin{array}{l}\text { Simmonds (1966), Dingley et al. (1981), Lu et al. (2000), Gorter (1977), } \\
\text { Crous et al. (2000), Meyer et al. (2001, 2006), Dingley et al. (1981) }\end{array}$ \\
\hline & Citrus reticulata & $\begin{array}{l}\text { Australia, Brazil, China, } \\
\text { Hong Kong, India, Japan, } \\
\text { Philippines }\end{array}$ & $\begin{array}{l}\text { Glienke et al. (2011), Wikee et al. (2011, 2013a, b), Miles et al. (2013), } \\
\text { Guarnaccia et al. (2017), Tran et al. (2019), Wang et al. (2012), Lu et al. } \\
\text { (2000), Zhuang (2001), Das et al. (2018), Kobayashi (2007), Tai (1979), Bai } \\
\text { (2000), Watson (1971), Simmonds (1966), Mendes et al. (1998) }\end{array}$ \\
\hline & $\begin{array}{l}\text { Citrus reticulata var. } \\
\text { poonensis }\end{array}$ & China & Tai (1979), Bai (2000) \\
\hline & $\begin{array}{l}\text { Citrus reticulata var. } \\
\text { suhoiensis }\end{array}$ & China & Tai (1979), Bai (2000) \\
\hline & Citrus reticulata var. sunki & China & Tai (1979), Bai (2000) \\
\hline & Citrus reticulata var. tankan & China & Tai (1979), Bai (2000) \\
\hline & Citrus sinensis & $\begin{array}{l}\text { Australia, Brazil, China, } \\
\text { Cook Islands, Fiji, Niue, } \\
\text { North America, Samoa, } \\
\text { South Africa, South Africa, } \\
\text { Mpumalanga, Tonga, } \\
\text { Uganda, Zimbabwe, } \\
\text { Angola, Florida, India, } \\
\text { Malta, Portugal, Tunisia }\end{array}$ & $\begin{array}{l}\text { Bassimba et al. (2018), Shivas (1989), Glienke et al. (2011), Wikee et al. } \\
\text { (2011, 2013a, b), Miles et al. (2013), Wulandari et al. (2009, 2013), Tran et } \\
\text { al. (2019), Mendes et al. (1998), Glienke et al. (2011), Guarnaccia et al. } \\
\text { (2017), Das et al. (2018), Boughalleb-M'Hamdi et al. (2020), Simmonds } \\
\text { (1966), Tai (1979), Bai (2000), Doidge (1950), Peres et al. (2007), Dingley et } \\
\text { al. (1981), Schubert et al. (2012), Gorter (1977), Crous et al. (2000), Meyer et } \\
\text { al. (2001, 2006), Reeder et al. (2008), Whiteside (1966) }\end{array}$ \\
\hline & Citrus sinensis $f$. sehkan & Taiwan & Anonymous (1979) \\
\hline & Citrus sinensis var. sekkan & China & Tai (1979), Bai (2000) \\
\hline
\end{tabular}


Supplementary Table 1 Continued.

\begin{tabular}{|c|c|c|c|}
\hline Species record & Host & Locality & References \\
\hline & Citrus sp. & $\begin{array}{l}\text { Angola, Argentina, } \\
\text { Australia, Bhutan, Brazil, } \\
\text { China, Cuba, Florida, } \\
\text { Ghana, India, Indonesia, } \\
\text { Italy, Japan, Kenya, Malta, } \\
\text { Mozambique, Namibia, } \\
\text { Nigeria, Philippines, } \\
\text { Portugal, South Africa, } \\
\text { Swaziland, Taiwan, } \\
\text { Uganda, United States, } \\
\text { Uruguay, Zambia, } \\
\text { Zimbabwe, Africa, Asia, } \\
\text { Australia, Fiji, Hong Kong, } \\
\text { New Zealand, United } \\
\text { States, West Indies }\end{array}$ & $\begin{array}{l}\text { Petrak (1953), Watson (1971), Mendes et al. (1998), Firman (1972), Dingley } \\
\text { et al. (1981), Zhuang (2001), Pennycook (1989), Bai (2000), Meyer et al. } \\
\text { (2001, 2006), Rossman (2009), Guarnaccia et al. (2019), Wikee et al. } \\
\text { (2013b), Guarnaccia et al. (2017), Trakunyingcharoen et al. (2015), Mendes } \\
\text { et al. (1998), Kobayashi (2007) }\end{array}$ \\
\hline & Citrus tankan & China & Zhuang (2001), Bai (2000) \\
\hline & Citrus tankan f. koshotankan & China & Bai (2000) \\
\hline & $\begin{array}{l}\text { Citrus tankan var. } \\
\text { koshotankan }\end{array}$ & China, Taiwan & Anonymous (1979), Tai (1979) \\
\hline & Citrus unshiu & Japan, Korea & Kobayashi (2007), Cho \& Shin (2004) \\
\hline & Diospyros halesioides & Cuba, West Indies & Urtiaga (1986, 2004), Minter et al. (2001) \\
\hline & Elaeis guineensis & Malaysia & Williams \& Liu (1976), Turner (1971) \\
\hline & Elettaria cardamomum & Tanzania & Ebbels \& Allen (1979) \\
\hline & Eucalyptus grandis & Malaysia, South Africa & Crous et al. (1989) \\
\hline & Fortunella crassifolia & China & Tai (1979), Bai (2000) \\
\hline & Jatropha podagrica & Cuba & Urtiaga (1986) \\
\hline & Mangifera indica & Florida & McMillan Jr. (1986) \\
\hline & Psidium guajava & Myanmar & Thaung (2008b) \\
\hline & Senna bicapsularis & Cuba & Lenne (1990), Boa \& Lenné (1994) \\
\hline & Zea mays & Malaysia & Williams \& Liu (1976) \\
\hline \multirow[t]{2}{*}{ P. citrichinansis } & Citrus maxima & China & Wang et al. (2012) \\
\hline & Citrus reticulata & China & Wang et al. (2012) \\
\hline P. citrimaxima & Citrus maxima & Thailand & Wikee et al. (2013b) \\
\hline \multirow[t]{2}{*}{ P. concentrica } & Corynocarpus laevigatus & New Zealand & Gadgil (2005) \\
\hline & Cryptomeria japonica & $\begin{array}{l}\text { District of Columbia, } \\
\text { Japan, Korea, Virginia }\end{array}$ & $\begin{array}{l}\text { Brittingham \& O'Brien (1978), Petrini et al. (1991), Leuchtmann et al. (1992), } \\
\text { Shaw et al. (2006), Motohashi et al. (2009), Cho \& Shin (2004) }\end{array}$ \\
\hline
\end{tabular}


Supplementary Table 1 Continued.

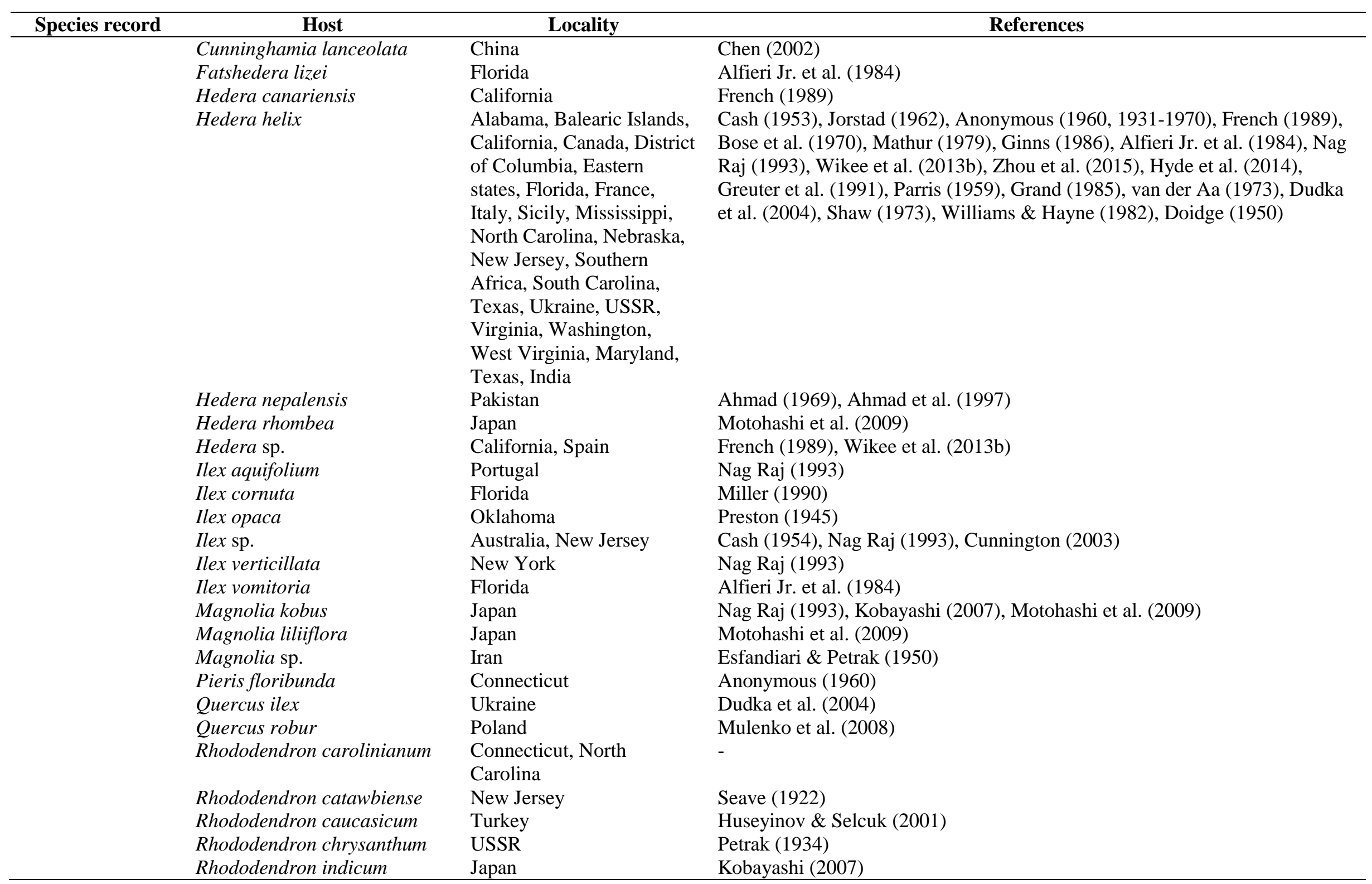


Supplementary Table 1 Continued.

\begin{tabular}{|c|c|c|c|}
\hline Species record & Host & Locality & References \\
\hline & Rhododendron keiskei & Japan & Motohashi et al. (2009) \\
\hline & Rhododendron macrophyllum & California, Washington & BPI n/a) \\
\hline & Rhododendron maximum & $\begin{array}{l}\text { Connecticut, District of } \\
\text { Columbia, Massachusetts, } \\
\text { New York, New Jersey, } \\
\text { West Virginia }\end{array}$ & $\begin{array}{l}\text { Clinton (1908, 1934), Ellis \& Everhart (1888), Seave (1922), Davis (1946), } \\
\text { Nag Raj (1993), Cash (1953), Eglitis et al. (1966) }\end{array}$ \\
\hline & Rhododendron maximum & New Jersey, West Virginia & Eglitis et al. (1966) \\
\hline & Rhododendron micranthum & China & Bai (2000) \\
\hline & Rhododendron mucronatum & Japan & Kobayashi (2007) \\
\hline & Rhododendron mucronulatum & Korea & Cho \& Shin (2004) \\
\hline & Rhododendron obtusum & Japan & Kobayashi (2007) \\
\hline & Rhododendron ponticum & $\begin{array}{l}\text { France, Portugal, Turkey, } \\
\text { USSR }\end{array}$ & Vanev \& van der Aa (1998), Huseyinov \& Selcuk (2001), Jaczewski (1915) \\
\hline & Rhododendron simsii & Japan & Kobayashi (2007) \\
\hline & Rhododendron sp. & $\begin{array}{l}\text { Canada, Japan, } \\
\text { Netherlands, New Jersey, } \\
\text { New York, Oklahoma, } \\
\text { United States, Virginia, } \\
\text { Washington, England, } \\
\text { France, New Jersey, } \\
\text { Portugal }\end{array}$ & $\begin{array}{l}\text { Brunaud (1890), Martin (1931), Pirone (1939), White (1933), Seaver (1922), } \\
\text { Camara (1930), White \& Hamilton (1935), Tengwall (1924), Preston (1945), } \\
\text { Kobayashi (2007), Motohashi et al. (2009), van der Aa (1973) }\end{array}$ \\
\hline & Taxus baccata & Germany, Poland & van der Aa (1973), Lotz-Winter et al. (2011), Mulenko et al. (2008) \\
\hline & Taxus brevifolia & $\begin{array}{l}\text { Idaho, Montana, } \\
\text { Washington }\end{array}$ & Anonymous (1960), Shaw (1973) \\
\hline & Taxus cuspidata & Poland & Mulenko et al. (2008) \\
\hline & Umbellularia californica & California & French (1989) \\
\hline \multirow[t]{2}{*}{ P. cussonia } & Cussonia sp. & South Africa & Wikee et al. (2013b) \\
\hline & Cussonia umbellifera & South Africa & Wikee et al. (2013b) \\
\hline \multirow[t]{2}{*}{ P. elongata } & Oxycoccus macrocarpos & United States & Wikee et al. (2013b) \\
\hline & Vaccinium macrocarpon & Massachusetts, Wisconsin & Weidemann et al. (1982) \\
\hline P. ericarum & Erica gracilis & $\begin{array}{l}\text { South Africa, South Africa, } \\
\text { Western Cape }\end{array}$ & $\begin{array}{l}\text { Wikee et al. (2013b), Zhou et al. (2015), Hyde et al. (2014), Crous et al. } \\
\text { (2012b) }\end{array}$ \\
\hline \multirow[t]{2}{*}{ P. gardeniicola } & Gardenia jasminoides & India, Japan, Taiwan & $\begin{array}{l}\text { Sarbhoy et al. (1971), Mathur (1979), Kobayashi (2007), Kobayashi \& Sasaki } \\
\text { (1975), Motohashi et al. (2009), Anonymous (1979) }\end{array}$ \\
\hline & $\begin{array}{l}\text { Gardenia jasminoides var. } \\
\text { radicans }\end{array}$ & Japan & Kobayashi (2007) \\
\hline
\end{tabular}


Supplementary Table 1 Continued.

\begin{tabular}{|c|c|c|c|}
\hline Species record & Host & Locality & References \\
\hline P. harai & Aucuba japonica & Japan & Kobayashi (2007), Motohashi et al. (2009) \\
\hline P. hostae & Hosta plantaginea & China & Su \& Cai (2012), Wikee et al. (2013b), Zhou et al. (2015), Hyde et al. (2014) \\
\hline $\begin{array}{l}P . \\
\text { hymenocallidicola }\end{array}$ & Hymenocallis littoralis & Australia & $\begin{array}{l}\text { Crous et al. (2011), Wikee et al. (2013b), Zhou et al. (2015), Hyde et al. } \\
\text { (2014) }\end{array}$ \\
\hline \multirow[t]{5}{*}{ P. hypoglossi } & Ruscus aculeatus & Italy, Sicily, Portugal & $\begin{array}{l}\text { Wulandari et al. (2009), Sultan et al. (2011), Glienke et al. (2011), Wikee et } \\
\text { al. (2011, 2013a, b), Zhou et al. (2015), Guarnaccia et al. (2017), Zhu et al. } \\
\text { (2018), Hyde et al. (2014), Greuter et al. (1991), Nag Raj (1993) }\end{array}$ \\
\hline & Ruscus hypoglossum & France, Italy & Wikee et al. (2011, 2013a, b), Wulandari et al. (2009), Glienke et al. (2011) \\
\hline & Ruscus ponticus & Ukraine & Dudka et al. (2004) \\
\hline & Ruscus sp. & $\begin{array}{l}\text { France, Italy, Portugal, } \\
\text { Turkey, Ukraine }\end{array}$ & Wikee et al. (2011), Nag Raj (1993) \\
\hline & Ruscus hypoglossum & Portugal & Nag Raj (1993), Costa \& Camara (1952) \\
\hline P. iridigena & Iris sp. & South Africa & Marin-Felix et al. (2019) \\
\hline P. kerriae & Kerria japonica & Japan & $\begin{array}{l}\text { Motohashi et al. (2008, 2009), Wikee et al. (2011, 2013a), Zhou et al. (2015), } \\
\text { Hyde et al. (2014) }\end{array}$ \\
\hline P. kobus & Magnolia kobus & Japan & Nag Raj (1993), Motohashi et al. (2009) \\
\hline P. ophiopogonis & Ophiopogon japonicus & South Korea, Thailand & Kwon et al. (2015), Wikee et al. (2012, 2013a, b) \\
\hline \multirow[t]{2}{*}{ P. paracitricarpa } & Citrus limon & Greece & Guarnaccia et al. (2017), Tran et al. (2019) \\
\hline & Citrus sinensis & China & Guarnaccia et al. (2017) \\
\hline P. speewahensis & Vanda sp. & Australia & Shivas et al. (2013) \\
\hline \multirow[t]{10}{*}{ P. spinarum } & Chamaecyparis lawsoniana & New Zealand & Gadgil (2005) \\
\hline & Chamaecyparis pisifera & France & $\begin{array}{l}\text { Shaw et al. (2006), Sultan et al. (2011), Glienke et al. (2011), Wikee et al. } \\
\text { (2011, 2013a, b), Zhou et al. (2015), Guarnaccia et al. (2017), Hyde et al. } \\
\text { (2014) }\end{array}$ \\
\hline & Cryptomeria japonica & New Zealand & Gadgil (2005) \\
\hline & Cupressus arizonica & New Zealand & Gadgil (2005) \\
\hline & Cupressus macrocarpa & New Zealand & Gadgil (2005) \\
\hline & Hedera helix & Italy & Glienke et al. (2011), Wikee et al. (2011) \\
\hline & Juniperus chinensis & New Zealand & Gadgil (2005) \\
\hline & Juniperus sp. & France, Germany & Wikee et al. (2013b) \\
\hline & Taxus baccata & Lithuania & Treigiene (2006) \\
\hline & Thuja plicata & New Zealand & Gadgil (2005) \\
\hline \multicolumn{4}{|c|}{ P. owaniana species complex } \\
\hline P. austroafricana & Unidentified host & South Africa & Crous et al. (2019) \\
\hline P. carissicola & Carissa macrocarpa & South Africa, Eastern Cape & Crous et al. (2015) \\
\hline P. hagahagaensis & Carissa bispinosa & South Africa & Crous et al. (2019) \\
\hline
\end{tabular}


Supplementary Table 1 Continued.

\begin{tabular}{|c|c|c|c|}
\hline Species record & Host & Locality & References \\
\hline P. owaniana & Brabejum stellatifolium & South Africa & $\begin{array}{l}\text { Swart et al. (1998), Crous et al. (2000), Wulandari et al. (2009), Sultan et al. } \\
\text { (2011), Glienke et al. (2011), Wikee et al. (2011, 2013a, b), Miles et al. } \\
\text { (2013), Zhou et al. (2015), Hyde et al. (2014), Doidge (1950) }\end{array}$ \\
\hline \multirow{3}{*}{ P. podocarpi } & Podocarpus falcatus & South Africa & Wikee et al. (2013a, b) \\
\hline & Podocarpus lanceolata & South Africa & $\begin{array}{l}\text { Sultan et al. (2011), Wikee et al. (2013b), Zhou et al. (2015), Hyde et al. } \\
\text { (2014) }\end{array}$ \\
\hline & Podocarpus latifolia & South Africa, Mpumalanga & Shaw et al. (2006) \\
\hline \multirow[t]{6}{*}{ P. pseudotsugae } & Cryptomeria japonica & Japan & Petrini et al. (1991), Leuchtmann et al. (1992) \\
\hline & Pseudotsuga brevifolia & China & Petrini et al. (1991), Leuchtmann et al. (1992) \\
\hline & Pseudotsuga gaussenii & China & Petrini et al. (1991), Leuchtmann et al. (1992) \\
\hline & Pseudotsuga japonica & Japan & Petrini et al. (1991), Leuchtmann et al. (1992) \\
\hline & Pseudotsuga menziesii & United States & Wikee et al. (2013b), Zhou et al. (2015), Hyde et al. (2014) \\
\hline & Pseudotsuga sinensis & China & Petrini et al. (1991), Leuchtmann et al. (1992) \\
\hline
\end{tabular}

Supplementary Table 2 Size of ascospores, conidia, and spermatia of Phyllosticta recored species.

\begin{tabular}{|c|c|c|c|c|}
\hline Species & Ascospores $(\mu \mathrm{m})$ & Conidia size $(\mu \mathrm{m})$ & Spermatia $(\mu \mathrm{m})$ & Reference \\
\hline \multicolumn{5}{|c|}{ Phyllosticta cruenta species complex } \\
\hline P. acaciigena & - & $7-15 \times 3-5$ & - & Crous et al. (2016) \\
\hline P. aloeicola & - & $5-13 \times 3-4$ & - & Wikee et al. (2013b) \\
\hline P. ardisiicola & - & $7-11 \times 5-7.5$ & - & Motohashi et al. (2008) \\
\hline P. aristolochiicola & - & $7-16 \times 6.5-11$ & - & Crous et al. (2012b) \\
\hline P. azevinhi & - & $8-10 \times 4-5$ & - & Brotéria (1908) \\
\hline P. beaumarisii & - & $7.5-15 \times 6.5-8.75$ & - & Paul \& Blackburn (1986) \\
\hline P. brazilianiae & - & $(8-) 10-11(-12.5) \times(5-) 6(-7)$ & - & Glienke et al. (2011) \\
\hline P. capitalensis & - & $(10-) 11-12(-14) \times(5-) 6-7$ & - & Glienke et al. (2011) \\
\hline P. carochlae & - & $6-8.5 \times(9-) 10-12(-13)$ & - & Zhou et al. (2015) \\
\hline P. cavendishii & $(12-) 14-17(-18) \times(7-) 8-9(-10)$ & $(12-) 13-16(-17) \times 8-9(-10)$ & $6-7(-8) \times(1-) 2$ & Wong et al. (2012) \\
\hline P. cordylinophila & - & $10-17 \times 3-6$ & - & Wikee et al. (2013b) \\
\hline P. eugeniae & - & $12.4-14.8 \times 4.3-7.1$ & - & Chen (1967) \\
\hline P. fallopiae & - & $8.5-12.5 \times 6-7.5$ & - & Motohashi et al. (2008) \\
\hline P. ilicis-aquifolii & - & $10-18 \times 6-9$ & $5-8 \times 1.5-2.5$ & Su \& Cai (2012) \\
\hline P. maculata & $(17-) 19-23(-24) \times(8-) 9-11(-13)$ & $(15-) 16-19(-21) \times(9-) 10-12(-13)$ & $(10-) 11-13(-14) \times(1-) 2$ & Wong et al. (2012) \\
\hline P. mangiferae & - & $(8-) 10-12 \times(5-) 6-7$ & - & Glienke et al. (2011) \\
\hline
\end{tabular}


Supplementary Table 2 Continued.

\begin{tabular}{|c|c|c|c|c|}
\hline Species & Ascospores $(\mu \mathrm{m})$ & Conidia size $(\mu \mathrm{m})$ & Spermatia $(\mu \mathrm{m})$ & Reference \\
\hline P. mangifera-indicae & 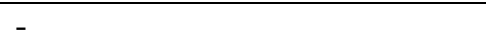 & $3-5 \times 3-4$ & 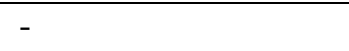 & Wikee et al. (2013b) \\
\hline P. musaechinensis & - & $14-18 \times 8-12$ & - & Wu et al. (2014) \\
\hline P. musarum & $(14-) 16-18(-21) \times 7-8(-9)$ & $(12-) 13-16(-20) \times(7-) 9-10(-11)$ & $(6-) 7-8(-9) \times(1-) 2$ & Wong et al. (2012) \\
\hline P. paracapitalensis & $16-17 \times 6(-7)$ & $(9-) 12-13(-14) \times(6-) 7$ & - & Guarnaccia et al. (2017) \\
\hline P. parthenocissi & - & $7.5-10 \times 6-9$ & - & Zhang et al. (2013b) \\
\hline P. partricuspidatae & - & $5-8.5 \times 8-12$ & $3-5(-7) \times 1-2.5$ & Zhou et al. (2015) \\
\hline P. philoprina & $16-20 \times 6-9$ & $10-15 \times 7-10$ & $6-15 \times 1.5-3$ & van der Aa (1973) \\
\hline P. rhizophorae & $(12.5-) 14-19(-21.5) \times 4.1-7.7$ & $(13-) 15-17(-19.5) \times 6-7(-8)$ & $7.5-11.5 \times 1-2$ & In this study \\
\hline P. schimae & - & $7-13 \times 4-7$ & $7-11 \times 1-2.5$ & Su \& Cai (2012) \\
\hline P. schimicola & - & $5-8 \times 8-11(-12)$ & - & Zhou et al. (2015) \\
\hline P. styracicola & - & $9.5-13 \times 6.5-9$ & - & Zhang et al. (2013a) \\
\hline P. vitis-rotundifoliae & - & $6-9.5 \times 9-13$ & - & Zhou et al. (2015) \\
\hline \multicolumn{5}{|c|}{ P. cruenta species complex } \\
\hline P. abieticola & $(15-) 16-18(-20) \times(6-) 7$ & $(11-) 13-16(-18) \times(7-) 8$ & - & Wikee et al. (2013b) \\
\hline P. cornicola & - & $(6-) 7-8 \times(5.5-) 6(-7)$ & - & Wikee et al. (2013b) \\
\hline P. cruenta & - & $12-21 \times 5-10$, mostly $16-19 \times 8-10$ & $4-9(-15) \times 1-2$ & van der Aa (1973) \\
\hline P. cryptomeriae & - & $9-13.5 \times 6.3-10.5$ & - & Petrini et al. (1991) \\
\hline P. foliorum & - & $(12-) 13-14(-15) \times(9-) 10(-11)$ & - & Wikee et al. (2013b) \\
\hline P. gaultheriae & - & $5-7 \times 4-5$ & - & Ellis et al. (1885) \\
\hline P. hakeicola & - & $(9-) 10-13(-15) \times(6.5-) 7$ & - & Crous et al. (2018) \\
\hline P. hamamelidis & - & $8.4-16.2 \times 6.0-10.3$ & - & Bissett \& Darbyshire (1984b) \\
\hline P. hubeiensis & - & $10-14.5 \times 6-9$ & $5.5-10 \times 1.2-2.3$ & Zhang et al. (2013a) \\
\hline P. illicii & - & $(12-) 13-15(-17) \times 7(-9)$ & $7-13 \times 2-3$ & Lin et al. (2017) \\
\hline P. leucothoicola & - & $(6-) 7-8(-9) \times 6(-7)$ & $5-7 \times 2-3$ & Wikee et al. (2013b) \\
\hline P. ligustricola & - & $7.4-14.7 \times 4.9-7.4$ & - & Motohashi et al. (2008) \\
\hline P. minima & - & $(9-) 10-11(-12) \times\left(6^{-}\right) 7(-8)$ & - & Wikee et al. (2013b) \\
\hline P. neopyrolae & - & $\left(6^{-}\right) 7(-8) \times\left(5^{-}\right) 6(-7)$ & - & Wikee et al. (2013b) \\
\hline P. pachysandricola & - & $5.5-8.5 \times 4.5-7.5$ & - & Wikee et al. (2013b) \\
\hline P. paxistimae & - & $(10-) 12-14(-16) \times 6-7(-8)$ & - & Wikee et al. (2013b) \\
\hline P. podocarpicola & - & $12-13(-16) \times 8-9(-9.5)$ & - & Wikee et al. (2013b) \\
\hline P. pyrolae & - & $4.5-7.5 \times 4-9$ & $4-6 \times 1.5-2$ & van der Aa (1973) \\
\hline P. rubella & $(8-) 9-10(-12) \times(4-) 5$ & $\left(6^{-}\right) 6.5-7(-8) \times(4-) 5(-5.5)$ & - & Wikee et al. (2013b) \\
\hline P. paviae & - & $11-15 \times 7-9$ & - & Jagiełło et al. (2019) \\
\hline
\end{tabular}


Supplementary Table 2 Continued.

\begin{tabular}{|c|c|c|c|c|}
\hline Species & Ascospores ( $\mu \mathrm{m})$ & Conidia size $(\mu \mathrm{m})$ & Spermatia $(\mu \mathrm{m})$ & Reference \\
\hline P. telopeae & - & $14-16.5 \times 8-9.5$ & - & Yip (1989) \\
\hline \multicolumn{5}{|c|}{ P. vaccinii species complex } \\
\hline P. vaccinii & - & $7-11 \times 4.5-7$ & - & Zhang et al. (2013b) \\
\hline P. vacciniicola & - & $(9-) 10-12(-13) \times(6-) 7(-8)$ & - & Wikee et al. (2013b) \\
\hline \multicolumn{5}{|c|}{ Phyllosticta rhodorae species complex } \\
\hline P. mimusopisicola & - & $10-11(-12) \times(5.5-) 6-6.5(-7)$ & $7-15 \times 1.5-2$ & Crous et al. (2014) \\
\hline P. rhodorae & - & $10-14 \times 7-8.7$ & $5.0-8.5 \times 1-1.5$ & Davis (1946) \\
\hline \multicolumn{5}{|c|}{ P. concentrica species complex } \\
\hline P. aspidistricola & - & $9.5-12.5 \times 8.5-10$ & - & Motohashi et al. (2008) \\
\hline $\begin{array}{l}\text { P. aucubae- } \\
\text { ianonicae }\end{array}$ & - & & - & Hernandez-Restrepo et al. \\
\hline P. bifrenariae & - & $\begin{array}{l}10-13 \times 5-8.5 \\
(10-) 11-13(-16) \times(7-) 8-9\end{array}$ & $5-10 \times 1.5-2$ & Glienke et al. (2011) \\
\hline P. catimbauensis & - & $(8.5-) 9.5(-10.5) \times 5.5-6$ & $5.5-9.5 \times 1.5-2$ & Crous et al. (2017) \\
\hline P. citriasiana & - & $(10-) 12-14(-16) \times(5-) 6-7(-8)$ & $3-5 \times 1-2$ & Wulandari et al. (2009) \\
\hline P. citribrasiliensis & - & $(8-) 10-12(-13) \times 6-7(-8)$ & - & Glienke et al. (2011) \\
\hline P. citricarpa & - & $6-13 \times 5-9$ & $5-8 \times 0.5-1$ & van der Aa (1973) \\
\hline P. citrichinensis & $(13-) 14-20(-21) \times(6-) 7-8(-9)$ & $(7-) 8-12(-13) \times 6-9$ & $7-9 \times 1-2$ & Wang et al. (2012) \\
\hline P. citri-maxima & - & $5(-8) \times(3-) 4(-7)$ & - & Wikee et al. (2013b) \\
\hline P. concentrica & - & $(10-) 11-13(-14) \times(6-) 8(-9)$ & - & Wikee et al. (2013b) \\
\hline P. cussonia & - & $(10-) 12-15(-17) \times(6-) 7(-8)$ & $7-10 \times 2-3$ & Wikee et al. (2013b) \\
\hline P. elongata & - & $9-14 \times 5-8$ & - & Weidemann et al. (1982) \\
\hline P. ericarum & - & $\left(8^{-}\right) 9-10(-12) \times\left(6^{-}\right) 7$ & - & Crous et al. (2012a) \\
\hline P. gardeniicola & - & $3.6-6.0 \times 1.5-2.7$ & - & Mhaiskar (1968) \\
\hline P. harai & - & - & - & $\begin{array}{l}\text { Motohashi et al. (2009) *in } \\
\text { valid }\end{array}$ \\
\hline P. hostae & - & $8-15 \times 5-9$ & - & Su \& Cai (2012) \\
\hline P. hymenocallidicola & - & $(8-) 9-10(-11) \times(6-) 6.5-7$ & - & Crous et al. (2011) \\
\hline P. hypoglossi & - & $8-15(-18) \times 6-10$ & - & Аа (1973) \\
\hline P. iridigena & - & $(10-) 12-13(-15) \times(7-) 8(-9)$ & - & Marin-Felix et al. (2019) \\
\hline P. kerriae & - & $9.5-12.5 \times 6-7.5$ & - & Motohashi et al. (2008) \\
\hline P. kobus & - & $9-12 \times 6-8$ & - & Hennings (1905) \\
\hline P. ophiopogonis & - & $10-14 \times 7-8$ & $6.7-8.3 \times 1.3-1.6$ & Wikee et al. (2013b) \\
\hline P. paracitricarpa & - & $(9-) 11-13(-15) \times 7-8(-9)$ & - & Guarnaccia et al. (2017) \\
\hline
\end{tabular}


Supplementary Table 2 Continued.

\begin{tabular}{|c|c|c|c|c|}
\hline Species & Ascospores $(\mu \mathrm{m})$ & Conidia size $(\mu \mathrm{m})$ & Spermatia $(\mu \mathrm{m})$ & Reference \\
\hline P. speewahensis & - & $10-13.5 \times 7.5-9$ & - & Shivas et al. (2013b) \\
\hline P. spinarum & - & $(10-) 12-14(-15) \times(7-) 7.5(-8)$ & - & Wikee et al. (2013b) \\
\hline \multicolumn{5}{|c|}{ P. owaniana species complex } \\
\hline P. austroafricana & - & $(11-) 14-17(-23) \times(6-) 8-10(-11)$ & $6-8 \times 2-3$ & Crous et al. (2019) \\
\hline P. carissicola & - & $(11-) 12-14(-15) \times(9-) 10(-11)$ & - & Crous et al. (2015) \\
\hline P. hagahagaensis & - & $(11-) 13-14(-15) \times(7-) 8(-9)$ & - & Crous et al. (2019) \\
\hline P. owaniana & - & $(10-) 11-12(-13) \times(7-) 8(-9)$ & - & Wikee et sl. (2013b) \\
\hline P. podocarpi & $(19-) 20(-23) \times(7-) 8(-9)$ & $(10-) 14(-17) \times(8-) 9(-10)$ & $(6-) 10(-11) \times(2-) 2.5(-3)$ & Crous et al. (1996) \\
\hline P. pseudotsugae & - & $6.7-13.5 \times 5-9$ & - & Petrini et al. (1991) \\
\hline
\end{tabular}




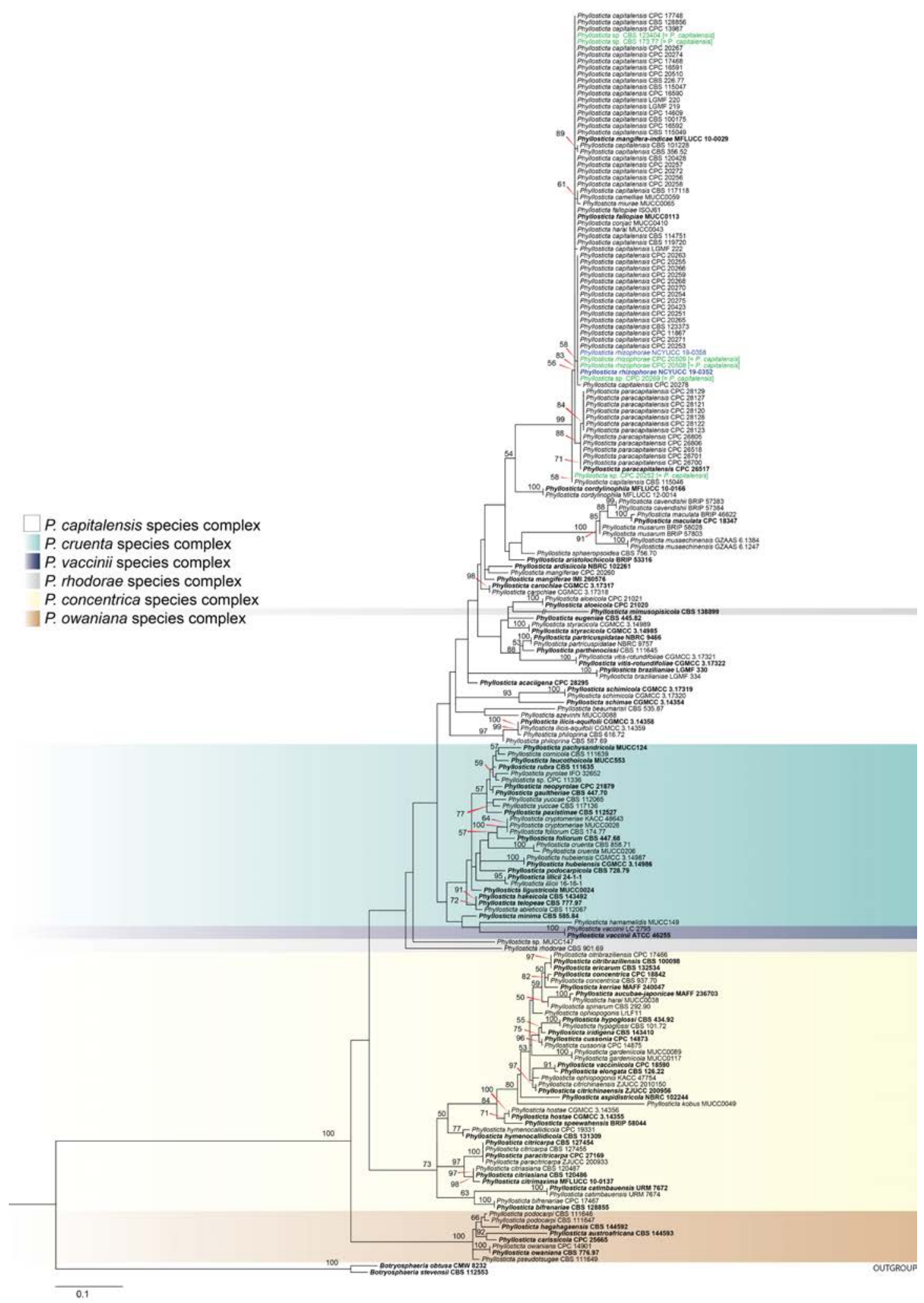

Supplementary Figure 1 - Phylogram generated using maximum likelihood analysis based on ITS sequence data from 195 strains. The tree is artificially rooted to Botryosphaeria obtusa strain CMW 8232 and Botryosphaeria stevensii strain CBS 112553. Maximum likelihood bootstrap values $\leq 50 \%$ are given at the nodes in this order. Species in six species complexes clades were kept hightlighted according to $P$. capitalensis species complex: White, $P$. cruenta species complex: Green, $P$. vaccinii species complex: Blue, $P$. rhodorae species complex: Gray, $P$. concentrica species complex: Yellow, and P. owaniana species complex: Brown. The species obtained in this study are in blue and species synonymized are in green. Ex-type taxa are in bold. 


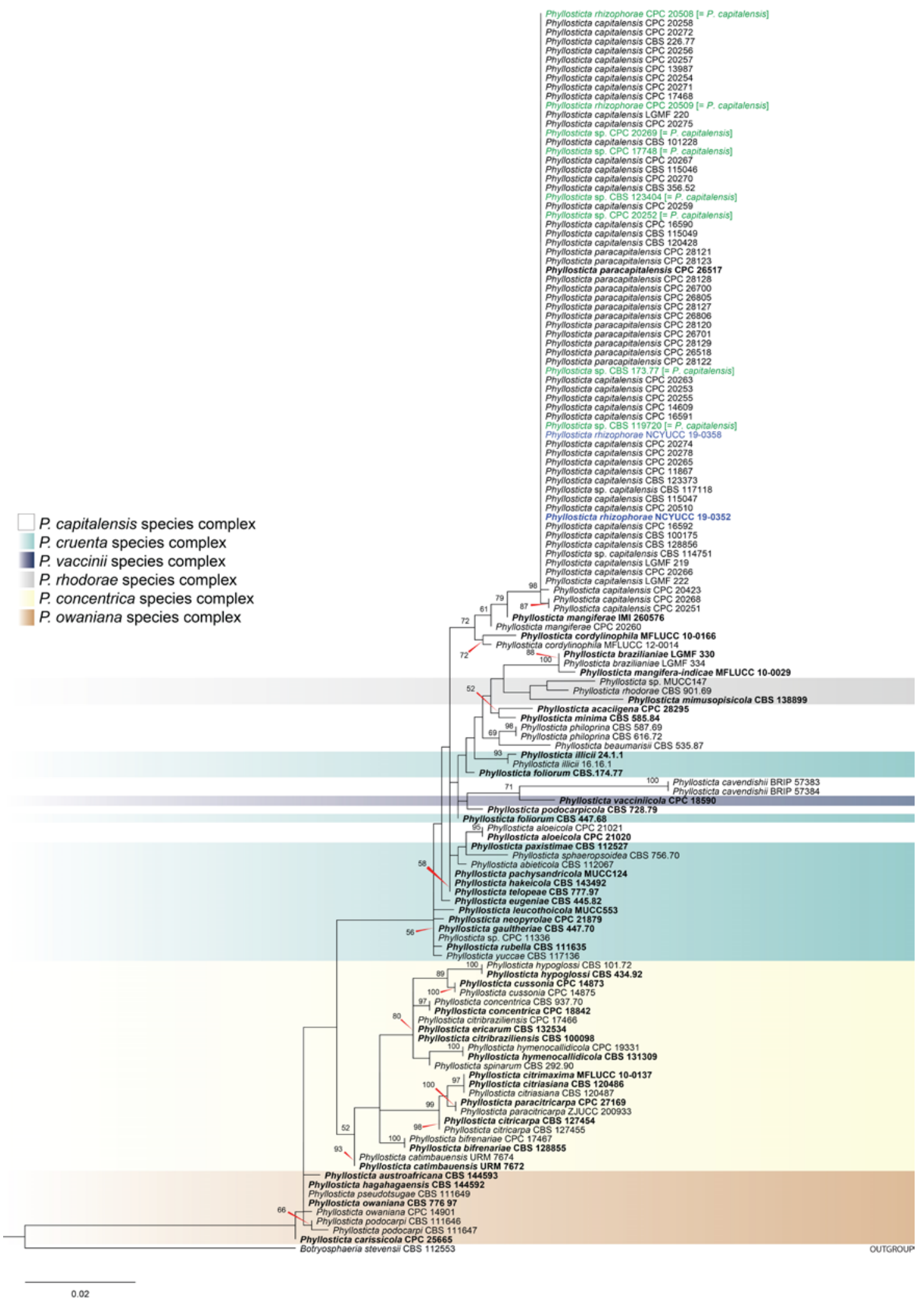

Supplementary Figure 2 - Phylogram generated using maximum likelihood analysis based on LSU sequence data from 136 strains. The tree is artificially rooted to Botryosphaeria stevensii strain CBS 112553. Maximum likelihood bootstrap values $\leq 50 \%$ are given at the nodes in this order. Species in six species complexes clades were kept hightlighted according to P. capitalensis species complex: White, $P$. cruenta species complex: Green, $P$. vaccinii species complex: Blue, $P$. rhodorae species complex: Gray, $P$. concentrica species complex: Yellow, and $P$. owaniana species complex: Brown. The species obtained in this study are in blue and species synonymized are in green. Ex-type taxa are in bold. 


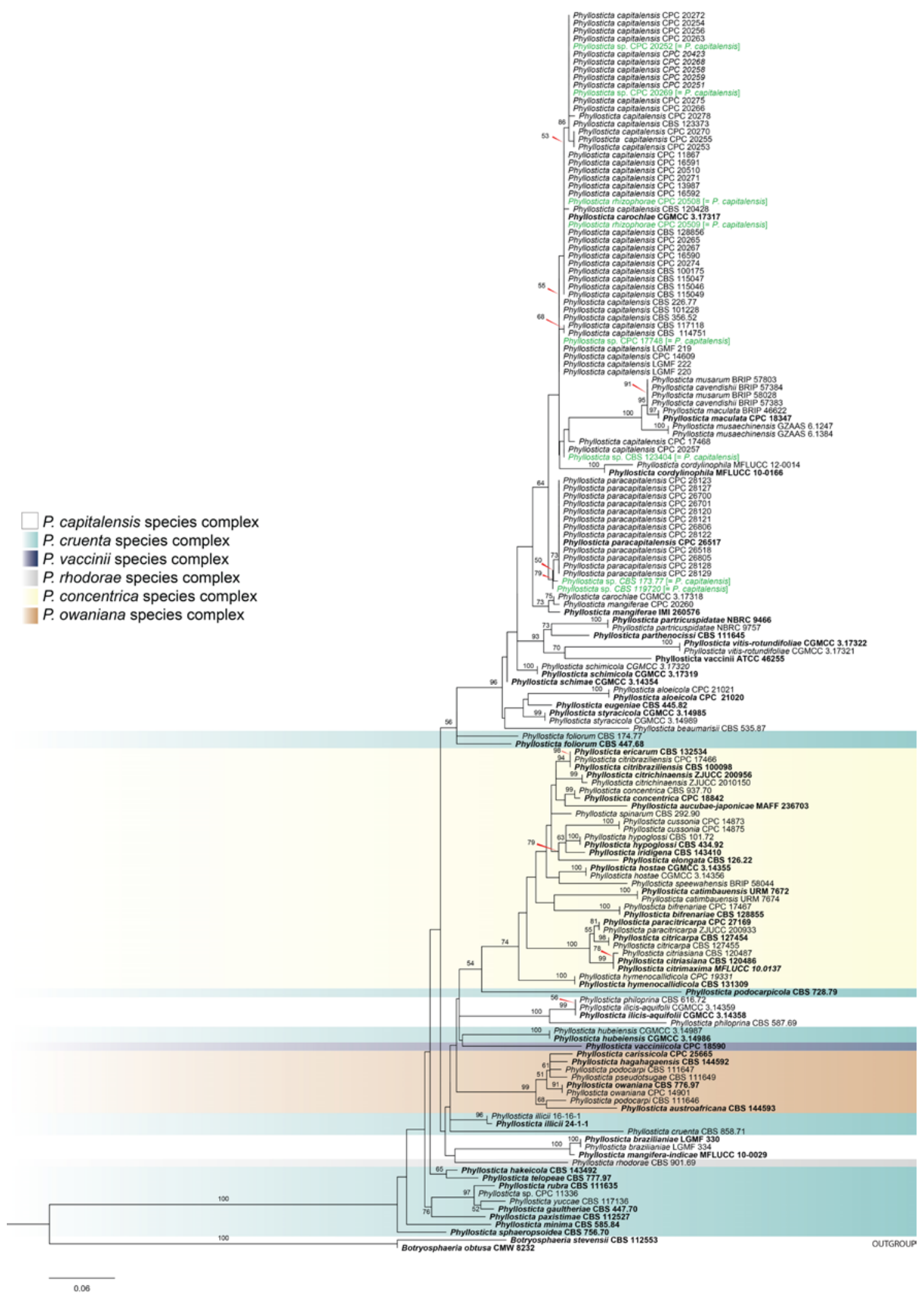

Supplementary Figure 3 - Phylogram generated using maximum likelihood analysis based on efl $\alpha$ sequence data from 160 strains. The tree is artificially rooted to Botryosphaeria obtusa strain CMW 8232 and Botryosphaeria stevensii strain CBS 112553. Maximum likelihood bootstrap values $\leq 50 \%$ are given at the nodes in this order. Species in six species complexes clades were kept hightlighted according to $P$. capitalensis species complex: White, $P$. cruenta species complex: Green, $P$. vaccinii species complex: Blue, $P$. rhodorae species complex: Gray, $P$. concentrica species complex: Yellow, and P. owaniana species complex: Brown. The species obtained in this study are in blue and species synonymized are in green. Ex-type taxa are in bold. 


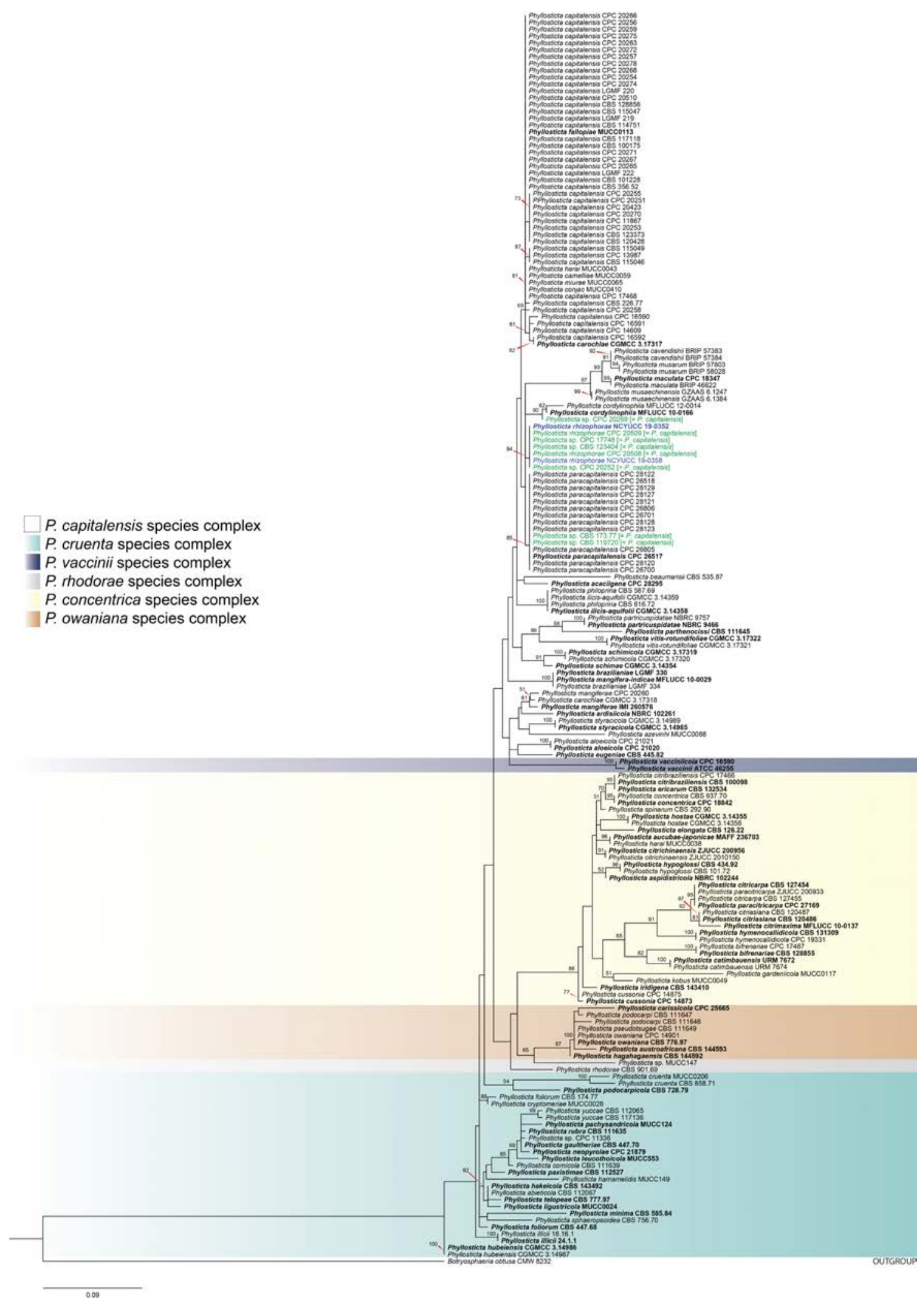

Supplementary Figure 4 - Phylogram generated using maximum likelihood analysis based on actin sequence data from 183 strains. The tree is artificially rooted to Botryosphaeria obtusa strain CMW 8232. Maximum likelihood bootstrap values $\leq 50 \%$ are given at the nodes in this order. Species in six species complexes clades were kept hightlighted according to $P$. capitalensis species complex: White, $P$. cruenta species complex: Green, $P$. vaccinii species complex: Blue, $P$. rhodorae species complex: Gray, $P$. concentrica species complex: Yellow, and $P$. owaniana species complex: Brown. The species obtained in this study are in blue and species synonymized are in green. Ex-type taxa are in bold. 


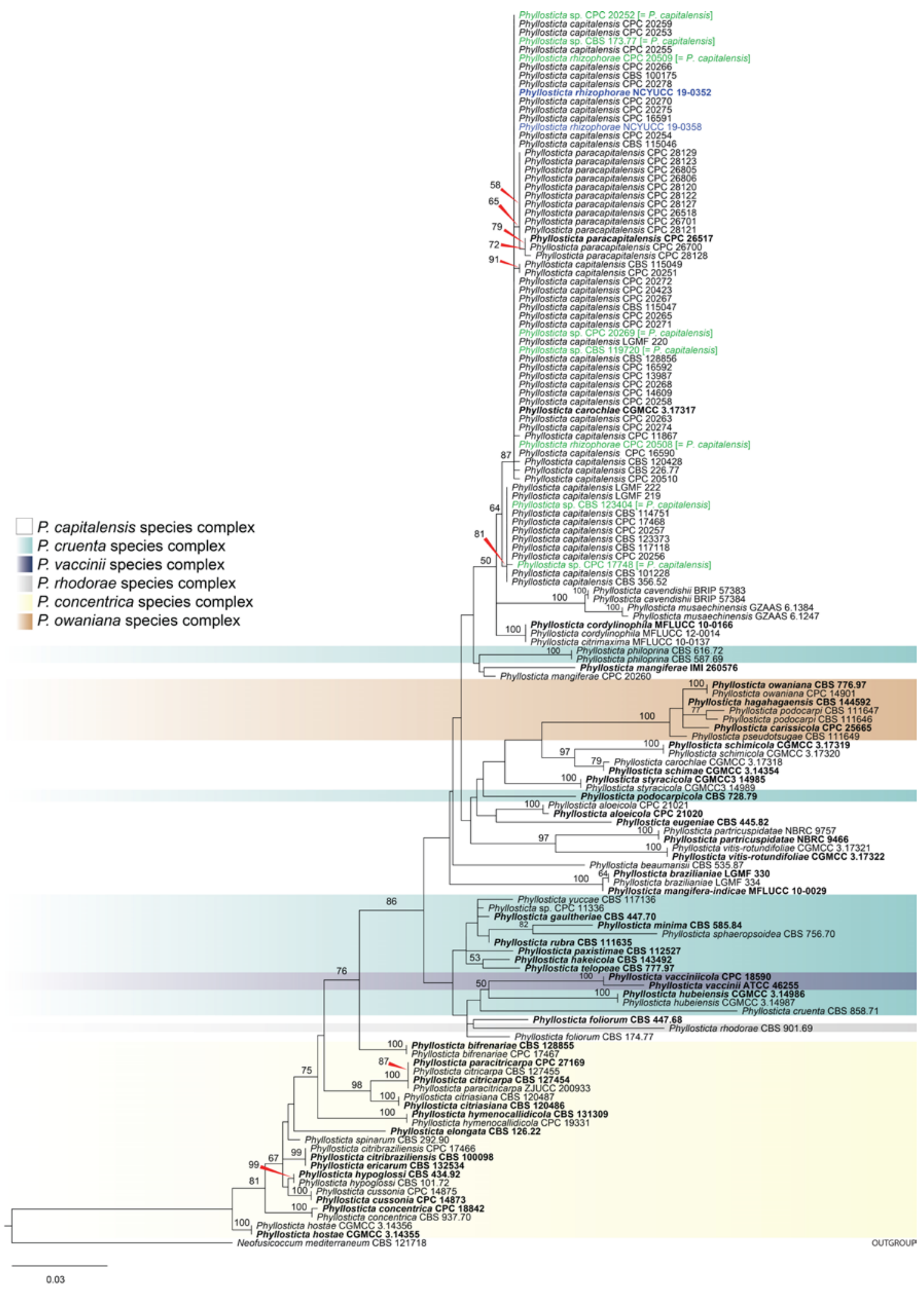

Supplementary Figure 5 - Phylogram generated using maximum likelihood analysis based on gapdh sequence data from 144 strains. The tree is artificially rooted to Neofusicoccum mediterraneum CBS 121718. Maximum likelihood bootstrap values $\leq 50 \%$ are given at the nodes in this order. Species in six species complexes clades were kept hightlighted according to $P$. capitalensis species complex: White, $P$. cruenta species complex: Green, $P$. vaccinii species complex: Blue, $P$. rhodorae species complex: Gray, P. concentrica species complex: Yellow, and $P$. owaniana species complex: Brown. The species obtained in this study are in blue and species synonymized are in green. Ex-type taxa are in bold. 